Report No. BMI-1434

UC-25 Metallurgy and Ceramics (TID-4500, 15th Ed.)

Contract No. W-7405-eng -92

\title{
PROGRESS RELATING TO CIVILIAN APPLICATIONS DURING APRIL, 1960
}

\section{by}

Russell W. Dayton

Clyde R. Tipton, Jr.

$$
\text { May 1, } 1960
$$




\section{DISCLAIMER}

This report was prepared as an account of work sponsored by an agency of the United States Government. Neither the United States Government nor any agency Thereof, nor any of their employees, makes any warranty, express or implied, or assumes any legal liability or responsibility for the accuracy, completeness, or usefulness of any information, apparatus, product, or process disclosed, or represents that its use would not infringe privately owned rights. Reference herein to any specific commercial product, process, or service by trade name, trademark, manufacturer, or otherwise does not necessarily constitute or imply its endorsement, recommendation, or favoring by the United States Government or any agency thereof. The views and opinions of authors expressed herein do not necessarily state or reflect those of the United States Government or any agency thereof. 


\section{DISCLAIMER}

Portions of this document may be illegible in electronic image products. Images are produced from the best available original document. 
REPORTS RELATING TO CIVILIAN APPLICATIONS ISSUED DURING APRIL, 1960 . . . . . . . . . . . . .

A. REACTOR MATERIALS AND COMPONENTS (AEC-DRD) . . . . . . . . . . . . . . . . . . . . A-1

Valence Effects of Oxide Additions to Uranium Dioxide . . . . . . . . . . . . . . . . . . A-2

High-Pressure High-Temperature Solid-State Studies . . . . . . . . . . . . . . . . . . A-3

Irradiation-Surveillance Program on Type 347 Stainless Steel . . . . . . . . . . . . . . . A-4

Development of High-Strength Niobium-Base Alloys . . . . . . . . . . . . . . . . . . . . A-7

Development of Corrosion-Resistant Niobium Alloys. . . . . . . . . . . . . . . . . . . A-9

Investigation of the Creep Properties of Zircaloy-2 During Irradiation at Elevated Temperatures. . . A-9

Determination of Oxygen in Sodium at Concentrations Below 10 PPM . . . . . . . . . . . . A-11

Wear and Friction of Sliding Surfaces in Liquid Sodium . . . . . . . . . . . . . . . . . A-ll

B. STUdies of FUEl Alloys (AEC-DRD) . . . . . . . . . . . . . . . . . . . . . . . . B-1

Development of Niobium-Uranium Alloys . . . . . . . . . . . . . . . . . . . . . B-2

Development of Thorium-Uranium Alloys . . . . . . . . . . . . . . . . . . . . . . . . . . . . . . . . . B-5

Irradiation-Capsule Studies of Uranium-Thorium and Uranium-Niobium . . . . . . . . . . . . B-8

C. FISSION-GAS RELEASE FROM REFRACTORY FUELS (AEC-DRD) . . . . . . . . . . . . . . . C-1

Diffusion in $\mathrm{UO}_{2}$. . . . . . . . . . . . . . . . . . . . . . . . . . . . . . . . . . . . . C-2

Characterization of Sintered $\mathrm{UO}_{2}$ and Model of Gas Release . . . . . . . . . . . . . . . . . . C-2

In-Pile Study of Gas Release. . . . . . . . . . . . . . . . . . . . . . . . . . . . . . . . . . C-3

D. GENERAL FUEL-ELEMENT DEVElOPMENT (AEC-DRD) . . . . . . . . . . . . . . . . . . D-

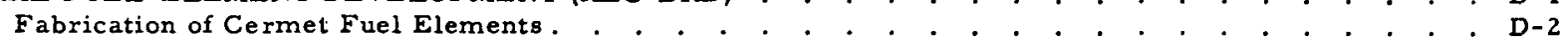

B Gas-Pressure Bonding of Molybdenum-and Niobium-Clad Fuel Elements. . . . . . . . . . . D-2

Factors Affecting Pressure Bonding . . . . . . . . . . . . . . . . . . . . . . . D-3

E. GAS-PRESSURE BONDING OF CERAMIC, CERMET, AND DISPERSION FUEL ELEMENTS

(AEC-FUEL CYCLE) . . . . . . . . . . . . . . . . . . . . . . . . . . . . . . . . . . . . . . E-1

Uranium Dioxide Compaction Studies . . . . . . . . . . . . . . . . . . . . . . . . . . . . . E-2

Gas-Pressure Bonding. . . . . . . . . . . . . . . . . . . . . . . . . . . . E-3

F. DEVELOPMENT OF URANIUM CARBIDE (AEC-FUEL CYCLE) . . . . . . . . . . . . . . . . . . F- 1

Alternate Fabrication Method for UC . . . . . . . . . . . . . . . . . . . . . . . F-2

Melting and Casting Techniques for Uranium-Carbon Alloys . . . . . . . . . . . . . . . F-4

Mechanical and Physical Properties of Uranium Monocarbide . . . . . . . . . . . . . . . F-5

Uranium Monocarbide Diffusion Studies . . . . . . . . . . . . . . . . . . . . . . . . F-9

Irradiation Effects in UC . . . . . . . . . . . . . . . . . . . . . . . . . . . F-10

G. PHYSICAL RESEARCH (AEC-DR). . . . . . . . . . . . . . . . . . . . . . . . . . . G-1

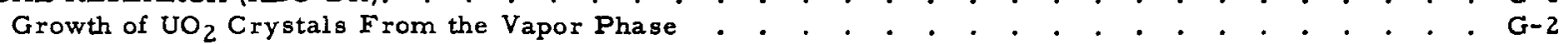

Fusion Methods to Prepare Single Crystals of $\mathrm{UO}_{2}$. . . . . . . . . . . . . . . . . . . . . G-2

H. RADIOISOTOPE AND RADIATION APPLICATIONS (AEC-OID) . . . . . . . . . . . . . . . . . H-

Development of Radioactive-Tracer Quality-Control Systems . . . . . . . . . . . . . . . H-2

Use of Intrinsic Radioactive Tracers for Process Control . . . . . . . . . . . . . . . . . . H-3

Graft-Polymerization Studies . . . . . . . . . . . . . . . . . . . . . . . . . . .

I. VOID-DISTRIBUTION AND HEAT-TRANSFER STUDIES (AEC-EURATOM) . . . . . . . . . . . . . . I- 1

J. MATERIALS AND DEVELOPMENT AND EVALUATION (HAPO). . . . . . . . . . . . . . . . . . J-1 Mechanical Properties of Zirconium Alloys. . . . . . . . . . . . . . . . . . . . . . . . . . . J-2

Development of Corrosion-Resistant Welding Alloys For Use With

Hastelloy $\mathrm{F}$ to Contain Decladding Solutions . . . . . . . . . . . . . . . . . . . . J-2

K. PREPARATION OF ALUMINUM-URANIUM ALlOYS (SCl) . . . . . . . . . . . . . . . . . . . . . K- 1

L. REFLECTIVE-INSULATION STUDIES (KAISER) . . . . . . . . . . . . . . . . . . . . . . L-1 
M. PROBLEMS ASSOCLATED WITH THE RECOVERY OF SPENT REACTOR FUEL ELEMENTS (ORNL). . . M-1

Corrosion Studies of the Fluoride-Volatility Process . . . . . . . . . . . . . . . . . . . .

Study of the Effects of Irradiation on Cladding- and Core-Dissolution Processes . . . . . . . M-2

N. VARIABLE-MODERATOR REACTOR CRITICAL-ASSEMBLY STUDIES (ATL-A) . . . . . . . . N N-I

o. URANIUM CARBIDE AS A REACTOR FUEL (AI) . . . . . . . . . . . . . . . . . . . . . . . . . . . O-1

Irradiation of Uranium Monocarbide . . . . . . . . . . . . . . . . . . . . . . . . . . O-2

Postirradiation Examination of Uranium Monoca rbide . . . . . . . . . . . . . . . . . . . . . $0-2$

P. PEBBLE-BED REACTOR MATERIALS (S \& P) . . . . . . . . . . . . . . . . . . . . . . . . . . . P- 1

LABORATORY DEVELOPMENT OF FUELED-GRAPHITE SPHERES . . . . . . . . . . . . . . . . . P-

FABRICATION DEVELOPMENT OF COATED FUEL PARTICLES . . . . . . . . . . . . . . . . . . . P-2

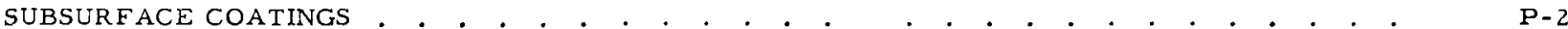

FISSION-PRODUCT RELEASE FROM FUELED-GRAPHITE SPHERES . . . . . . . . . . . . . . . . P-3

Neutron-Activation Studies . . . . . . . . . . . . . • . . . . . . . . . P-3

In-Pile Capsule Experiments . . . . . . . . . . . . . . . . . . . . . . . . . . . . . $\quad$. $\quad$.

Q. TANTALUM AND TANTALUM ALLOYS FOR LAMPRE APPLICATIONS (LASL). . . . . . . . . . . Q-

Development of Contaner Materials for LAMPRE Applications. . . . . . . . . . . . . . . . . . . $\quad$ Q-2

Precipitate Phase Identification and Interstitial-Type Solid Solubility in Tantalum . . . . . . Q-2

R. FLOW STUDIES FOR THE PWR (BAPD) . . . . . . . . . . . . . . . . . . . . . . . . R-1

S. DEVELOPMENT OF MATERIALS FOR THE MGCR AND HTGR (GA) . . . . . . . . . . . . . . . S- 1

High-Burnup Irradiation Effects in Fuel Materials . . . . . . . . . . . . . . . . . S-2

Thermal Conductivity of Beryllia. .

Preparation and Coating of Uranium and Thorium Carbide Powders . . . . . . . . . . . S-4

T. DEVELOPMENTAL STUDIES FOR THE SM-1 AND SM-2 (ALCO). . . . . . . . . . . . . . . . . . . T-1

SM-1 PROGRAM . . . . . . . . . . . . . . . . . . . . . . . . . . . . . . . . . . . . . . . .

Process Development for the Preparation of Instrumented Fuel Plates of the SM-1 Type . . . . T-2

SM-2 PROGRAM.

Radiation-Stability Studies of Reference and Alternate SM-2 Fuels. . . . . . . . . . . . . . . . . . . T-6

Fuel-Element Thermodynamics . . . . . . . . . . . . . . . . . . . . . . . . T-7

U. GAS-COOLED REACTOR PROGRAM (AGN) . . . . . . . . . . . . . . . . . . . . . . . . . U-

Fabrication of BeO-UO $\mathrm{U}_{2}$ Fuel Pellets . . . . . . . . . . . . . . . . . . . . . . . . . U-2

Study of Processing Variables in the Fabrication of BeO-UO 2 Ceramics. . . . . . . . . . U-2

Effects of Irradiation. . . . . . . . . . . . . . . . . . . . . . . . . . . . U-4

Alloy Modification of Hastelloy X . . . . . . . . . . . . . . . . . . . . . . . U-5

GCRE Critical-Assembly Experiments . . . . . . . . . . . . . . . . . . . . . . . . . . . . U-6

BRR Loop Program . . . . . . . . . . . . . . . . . . . . . . . . . . . . . . . . . . . . . . . . .

ETR Loop Program . . . . . . . . . . . . . . . . . . . . . . . . . . . . . .

V. CORROSION OF THORIUM AND URANIUM UNDER STORAGE CONDITIONS (LIVERMORE) . . . . . . . . V-

Electrodeposited Coatings for Thorium (SC) . . . . . . . . . . . . . . . . . . . . . . . V-2

Corrosion Evaluations (UCRL) . . . . . . . . . . . . . . . . . . . . . . . . V-2

W. A STUDY OF THE SOLUBILITY OF PLUTONIUM IN MOLTEN ALUMINUM-MAGNESIUM ALLOYS (DOW) . W-1

X. DEVELOPMENT OF $\mathrm{Al}_{2} \mathrm{O}_{3}-\mathrm{Cl} L \mathrm{DAO} \mathrm{U}_{2}$ FUEL PARTICLES (S \& P) . . . . . . . . . . . . . . . . . . X-1 
5 and 6

\section{REPOR TS RELATING TO CIVILIAN APPLICATIONS ISSUED DURING APRIL, 1960}

BMI-1417 "Development of High-Strength Niobium Alloys for Elevated-Temperature Applications", by John A. DeMastry, Frederic R. Shober, and Ronald F. Dickerson.

BMI-1419 "High-Temperature Irradiation of Metals and Graphite in Flowing Helium", by Neil E. Miller, Donald J. Hamman, Ward S. Diethorn, and William H. Goldthwaite.

BMI-1425 "Ir radiation-Capsule Study of Uranium Monocarbide", by Robert B. Price, David Stahl, John H. Stang, and Eugene M. Simons.

BMI-1427 "Dissolution of Irradiated Consolidated Edison Power-Reactor Fuel by the Sulfex and Darex Processes", by Robert A. Ewing, Harvey B. Brugger, and Duane N. Sunderman.

BMI- 1428 "Development of Thorium-Uranium-Base Fuel Alloys", by Martin S. Farkas, Arthur A. Bauer, and Ronald F. Dickerson.

BMI-1429 "The BMI-16 Recirculating Gas Loop Installed at the ETR", by Joseph V. Baum and Gerald A. Francis.

BMI- 1430 "Progress Relating to Civilian Applications During March, 1960", by Russell W. Dayton and Clyde R. Tipton, Jr. 


\title{
REACTOR MATERIALS AND COMPONENTS (AEC-DRD)
}

\author{
R. F. Dickerson
}

\begin{abstract}
Valence Effects of Oxide Additions to Uranium Dioxide . . . . . . A-2 High-Pressure High-Temperature Solid-State Studies . . . . . . A-3 Irradiation-Surveillance Program on Type 347 Stainless Steel . . . A-4 Development of High-Strength Niobium-Base Alloys . . . . . . A-7 Development of Corrosion-Resistant Niobium Alloys . . . . . . A-9 Investigation of the Creep Properties of Zircaloy-2 During

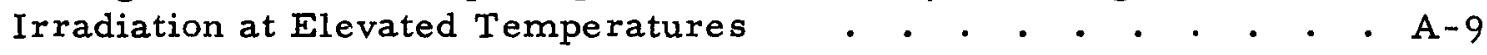
Determination of Oxygen in Sodium at Concentrations Below 10 PPM . . . . . . . . . . . . . . . . . . A-11 Wear and Friction of Sliding Surfaces in Liquid Sodium . . . . . . A-11
\end{abstract}

In an attempt to reduce the volatility of $\mathrm{U}_{3} \mathrm{O}_{8}$ (which becomes appreciable at temperatures above $1200 \mathrm{C}$ ) studies of oxidized solid solutions have been in progress. Thest materials have been prepared by direct solid-state sintering of $\mathrm{U}_{3} \mathrm{O}_{8}$ and $\mathrm{La}_{2} \mathrm{O}_{3}$ in air at $1375 \mathrm{C}$. The lattice parameters of these air-fired materials are different from those prepared by evaporation or coprecipitation. This suggests that physical properties will vary somewhat with the method of preparation. High-pressure and high-temperature solid-state studies show that $\mathrm{UO}_{2}$ and $\mathrm{Sc}_{2} \mathrm{O}_{3}$ form a solid solution under pressure. This does not occur in the absence of pressure. A reaction between $\mathrm{UO}_{2}$ and $\mathrm{MgO}$ under pressure also appears probable but no reaction between $\mathrm{U}_{3} \mathrm{O}_{8}$ and $\mathrm{Al}_{2} \mathrm{O}_{3}$ has been detected. Improved methods for temperature calibration of the high-pressure dies are being investigated since direct measurement by thermocouple has several serious mechanical disadvantages.

The irradiation of Type 347 stainless steel is continuing, and exposures as high as $6.15 \times 10^{21}$ nvt have been obtained. The two gamma-heat capsules in the WTR received no neutron exposure in April and will probably receive none in May because of a sustained reactor shutdown. As a result of flux measurements in connection with this program, it is apparent that multiple-cycle dosimeter exposures give indicated lower flux values than do single-cycle exposures.

The study concerned with the development of high-strength niobium-base alloys for use as a cladding material in the EBR-II has been continued after a brief period of inactivity. Relatively large heats of niobium-2. $0 \mathrm{w} / 0$ chromium, niobium-5. $3 \mathrm{w} / 0$ vanadium, niobium-3.0 w/o zirconium, and niobium-2.0 w/o zirconium-1.0 w/o chromium are being cast for continued study. Corrosion studies in 600 and $680 \mathrm{~F}$ water and $750 \mathrm{~F}$ 1500-psi steam are being continued on a number of niobium-base alloys. Exposure times range up to 392 days and the data continue to indicate that the most resistant alloys are a binary niobium -45 a/o zirconium and a ternary containing 28 a/o titanium and 6 a/o chromium.

A pressure mock-up of the capsule designed for the in-pile creep studies of Zircaloy- 2 has been constructed and subjected to internal fluid pressures up to 1000 psi without incident. Tensile-test results indicate the presence of strain aging in Zircaloy-2, and data obtained from internal-friction measurements performed in the 50 to $300 \mathrm{~F}$ 
temperature range seem to give an indication of the same phenomenon. The forced shutdown of the WTR may postpone insertion of the first test capsule until after July 1.

A mass spectrometric technique is being carefully evaluated as a means for measuring small amounts of oxygen in sodium. Since the analytical technique is dependent on the correct vaporization of sodium monoxide in the mass spectrometer, attempts are being made to obtain materials suitable for the necessary vaporization oven. This mate. rial must be nonreactive with both oxygen and sodium under the conditions prevailing in the mass spectrometer.

\section{Valence Effects of Oxide Additions to Uranium Dioxide}

W. B. Wilson and C. M. Schwartz

Solid-state studies of oxide additions to uranium oxide were continued. These additions are employed for two purposes:

(1) To eliminate the phase transformation to $\mathrm{U}_{3} \mathrm{O}_{8}$, which occurs when $\mathrm{UO}_{2}$ is exposed to an oxidizing environment at elevated temperatures

(2) To reduce the volatility of $\mathrm{U}_{3} \mathrm{O}_{8}$ which becomes appreciable at temperatures in excess of $1200 \mathrm{C}$.

The objective of the present program is to obtain an improved understanding of the operative mechanism of stabilization imparted by additions of $\mathrm{La}_{2} \mathrm{O}_{3}$ and $\mathrm{Y}_{2} \mathrm{O}_{3}$ to uranium oxide.

In previous work, "reduced" solid solutions of $\mathrm{UO}_{2}$ containing up to 60 mole per cent $\mathrm{La}_{2} \mathrm{O}_{3}$ and $\mathrm{Y}_{2} \mathrm{O}_{3}$ were prepared by direct solid-state reaction at $1750 \mathrm{C}$ in vacuo. These materials were then oxidized in air at temperatures up to $1760 \mathrm{C}$, and weightchange data were obtained for comparison with data for undoped $\mathrm{UO}_{2}$. Latticeparameter, conductivity, and thermoelectric-power measurements were obtained before and after oxidation. The results from this phase of the investigation have been reported previously.

Recent work has been directed toward study of the "oxidized" solid solutions, which also have the cubic fluorite structure. These materials were prepared by direct solid-state sintering of $\mathrm{U}_{3} \mathrm{O}_{8}$ and $\mathrm{La}_{2} \mathrm{O}_{3}$ in air at $1375 \mathrm{C}$. The purpose of this phase of the investigation was to prepare "fully oxidized" solid solutions equivalent to those reported by Hund and Peetz* for $\mathrm{U}_{3} \mathrm{O}_{8}-\mathrm{La}_{2} \mathrm{O}_{3}$. The lattice parameters obtained for the air-fired $\mathrm{U}_{3} \mathrm{O}_{8}-\mathrm{La}_{2} \mathrm{O}_{3}$ solid solutions were found to be considerably larger than those reported by Hund and were nearly identical to those obtained by air oxidation of the "reduced" $\mathrm{UO}_{2}-\mathrm{La}_{2} \mathrm{O}_{3}$ solid solutions reported previously.

The large difference between the Hund parameters and those of the present work indicated that the Hund material was more fully oxidized. However, it was not clear whether the Hund material was equivalent to $\mathrm{U}_{3} \mathrm{O}_{8}-\mathrm{La}_{2} \mathrm{O}_{3}$ or $\mathrm{UO}_{3}-\mathrm{La}_{2} \mathrm{O}_{3}$. Microbalance analysis of the air-fired $\mathrm{U}_{3} \mathrm{O}_{8}-\mathrm{La}_{2} \mathrm{O}_{3}$ was undertaken to determine the oxygento-uranium ratio. The results, given in Table A-1, together with lattice-parameter

\footnotetext{
"Hund, Von F., and Peetz, V., "Untersuchungen der Systeme $\mathrm{La}_{2} \mathrm{O}_{3}, \mathrm{Sm}_{2} \mathrm{O}_{3}, \mathrm{Yb}_{2} \mathrm{O}_{3}, \mathrm{Sc}_{2} \mathrm{O}_{3}$ mit $\mathrm{U}_{3} \mathrm{O}_{8}$ ", Z. anorg, u, allgem. Chem. , 271, 6 (1952-1953).
} 
values for variable oxygen content show that the air-fired material had dissociated to lower oxygen-to-uranium ratios than would correspond to $\mathrm{U}_{3} \mathrm{O}_{8}$. Moreover, the results indicate that the oxygen-to-uranium ratio varies with the lanthanum content; increasing $\mathrm{La}_{2} \mathrm{O}_{3}$ apparently allows the uranium to achieve a higher oxidation state.

TABLE A-1. COMPARISON OF LATTICE PARAMETERS OF URANIUM OXIDE-LANTHANUM OXIDE SOLID SOLUTIONS WITH VARLABLE OXYGEN CONTENT

\begin{tabular}{|c|c|c|c|c|c|c|}
\hline & & \multirow{3}{*}{$\begin{array}{l}\text { Analyzed } \\
\text { Ratio } \\
\text { Oxygen-to- } \\
\text { Uranium }\end{array}$} & \multicolumn{4}{|c|}{ Lattice Parameters, A } \\
\hline \multicolumn{2}{|c|}{ Composition, mole per cent } & & $\begin{array}{c}\text { Prepared at } \\
1375 \mathrm{C}\end{array}$ & $\begin{array}{l}\text { After } 5 \mathrm{Hr} \\
\text { at } 1760 \mathrm{C}\end{array}$ & $\begin{array}{l}\text { Equivalent Hund } \\
\text { Parameter }\end{array}$ & $\begin{array}{c}\text { Equivalent } \\
\mathrm{UO}_{2}-\mathrm{La}_{2} \mathrm{O}_{3}\end{array}$ \\
\hline Intended & Analyzed & & in Air & in $\mathrm{Air}$ & $\mathrm{UO}_{2.67}-\mathrm{La}_{2} \mathrm{O}_{3}^{\prime(a)}$ & Parameter \\
\hline $60 \mathrm{UO}_{2.67}-40 \mathrm{La}_{2} \mathrm{O}_{3}$ & $39.2 \mathrm{La}_{2} \mathrm{O}_{3}$ & 2.36 & 5.525 & 5.53 & 5.485 & 5.60 \\
\hline $50 \mathrm{UO}_{2.67}-50 \mathrm{La}_{2} \mathrm{O}_{3}$ & $48.8 \mathrm{La}_{2} \mathrm{O}_{3}$ & 2.46 & 5.552 & 5.551 & 5.508 & 5.635 \\
\hline $40 \mathrm{UO}_{2.67}-60 \mathrm{La}_{2} \mathrm{O}_{3}$ & $61.8 \mathrm{La}_{2} \mathrm{O}_{3}$ & 2.49 & 5.585 & 5.585 & 5.534 & 5.66 \\
\hline
\end{tabular}

(a) The oxygen-to-uranium ratios of the $\mathrm{UO}_{2.67}-\mathrm{La}_{2} \mathrm{O}_{3}$ solid solutions of Hund were not determined.

Although the dissociation produces relatively complex behavior, from a qualitative standpoint, the results of Hund indicate that more fully oxidized material may be produced. The Hund solid solutions were prepared by evaporation of nitrate solutions containing $\mathrm{U}_{3} \mathrm{O}_{8}$ and $\mathrm{La}_{2} \mathrm{O}_{3}$. These materials were calcined to oxides and ultimately sintered at $1200 \mathrm{C}$ in air. The nonequivalence of air-fired oxides and those prepared by evaporation or coprecipitation suggests that the physical properties will vary somewhat with the method of preparation.

Work will continue to define the "oxidized" solid solutions described above. Following the Hund method of preparation, more fully oxidized solid solutions will be prepared. Data on the lattice parameters, electrical properties, and high-temperature stability of these materials will be compared with the previous results.

$\underline{\text { High-Pressure High-Temperature Solid-State Studies }}$

W. B. Wilson and C. M. Schwartz

An investigation is being conducted to determine the effects of combined ultrahigh pressure and high temperature on uranium oxide and on reactions of uranium oxides with various mixed oxides. Previous research on this program has been directed toward the development of equipment capable of achieving pressures in excess of $100,000 \mathrm{~atm}$ and the determination of the effects of pressure and temperature on the uranium oxides $\mathrm{UO}_{2}$, $\mathrm{U}_{4} \mathrm{O}_{9}$, and $\mathrm{U}_{3} \mathrm{O}_{8}$. These phases of the present program have been completed.

A recalibration of both pressure and temperature was undertaken in current work because of changes introduced in sample configuration. The recalibration of pressure has been extended to 135,000 atm and was found to be the same as the previous calibration results. Work was continued on temperature calibration. Attempts to insert thermocouples into the high-pressure apparatus have continued to meet with poor results. 
The study of reactions of uranium oxides with various mixed oxides has continued. At present, emphasis is being placed on the study of the reaction of $\mathrm{UO}_{2}$ with $\mathrm{Sc}_{2} \mathrm{O}_{3}$ and $\mathrm{MgO}$, and of $\mathrm{U}_{3} \mathrm{O}_{8}$ with $\mathrm{Al}_{2} \mathrm{O}_{3}$. Structural studies of equimolar amounts of $\mathrm{UO}_{2}$ with $\mathrm{Sc}_{2} \mathrm{O}_{3}$ have shown solid-solution formation which was not observed to occur in the absence of pressure. A reaction between $\mathrm{UO}_{2}$ and $\mathrm{MgO}$ under pressure also appears probable. No reaction between $\mathrm{U}_{3} \mathrm{O}_{8}$ and $\mathrm{Al}_{2} \mathrm{O}_{3}$ has been detected, to date, except that the $\mathrm{U}_{3} \mathrm{O}_{8}$ transformed to the high-pressure modification previously reported.

In view of the difficulties of attempting temperature calibration with the thermocouple technique, several fresh approaches have been devised as alternate methods of temperature calibration. Two methods appear promising which may be employed simultaneously. A measure of the relative resistance increase with increasing temperature may be obtained from the knowledge of the voltage and current to the heater. In effect this is analogous to a determination of the temperature by use of the equation for temperature coefficient of resistance:

$$
R_{T}=R_{0}(1+\alpha T) K_{p} \text {, }
$$

where $\mathrm{K}_{\mathrm{p}}$ represents an arbitrarily determined constant at given pressure due to the change in thermal conductivity with pressure and the pressure coefficient of resistance. In practice, the resistance has been observed to increase uniformly, at given pressure up to the melting point of the platinum heater tube. In conjunction with this, thermocouples may also be employed, in which contact is made to the die components rather than attempting to bring the thermocouple wires out of the high-pressure apparatus.

Although thermocouples may be occasionally inserted into the apparatus successfully, the application of very high pressures usually severs the leads. Reaction studies at high pressure do not necessarily require high precision in temperature measurement, but a reliable estimate of temperature is mandatory for each individual experiment.

\section{Irradiation-Surveillance Program on Type 347 Stainless Steel}

W. E. Murr, F. R. Shober, R. L. Ritzman, and J. F. Lagedrost

A program to determine the effects of fast-neutron irradiation (neutrons with energies greater than $1 \mathrm{Mev}$ ) on the mechanical properties of AISI Type 347 stainless steel specimens is continuing. This program includes the postirradiation mechanical-property testing of subsize tensile, cyclic-strain fatigue, and impact specimens which are being irradiated over a range of exposures from 0.5 to $1.5 \times 10^{22} \mathrm{nvt}$ in high-fast-flux positions of the ETR and WTR. The information will be used primarily as a periodic evaluation of the effects of increased fast-neutron exposure occurring in the KAPL C-33 loop, which is being operated in the ETR.

Eleven capsules containing test specimens are operating in the ETR, and two capsules are operating in the WTR. Three of the eleven capsules have been in-pile since August, 1959, and eight have been in-pile since June, 1958. The two WTR capsules were inserted in February, 1960. The total exposures obtained upon all eleven ETR capsules as of the end of ETR Cycle 27 (March 28) are given in Table A-2. Exposures for the two WTR capsules are also reported. 
TABLE A -2. CAPSULES PREPARED FOR THE TYPE 347 STAINLESS STEEL IRRADIATION-SURVEULIANCE PROGRAM

\begin{tabular}{|c|c|c|c|c|c|c|c|c|}
\hline \multirow[b]{2}{*}{ Capsule } & \multirow{2}{*}{$\begin{array}{l}\text { Type of Specimens } \\
\text { in Capsule }\end{array}$} & \multirow{2}{*}{$\begin{array}{c}\text { Proposed } \\
\text { Irradiation } \\
\text { Temperature, } \\
\text { F }\end{array}$} & \multirow{2}{*}{$\begin{array}{l}\text { Approximate } \\
\text { Removal } \\
\text { Date(a) }\end{array}$} & \multirow{2}{*}{$\begin{array}{c}\text { Approximate Exposure } \\
\text { at Time of } \\
\text { Removal(b), nvt }\end{array}$} & \multicolumn{2}{|c|}{$\begin{array}{l}\text { Total Exposure as of } \\
\text { March 28, 1960, nvt }\end{array}$} & \multirow[b]{2}{*}{ Location } & \multirow[b]{2}{*}{ Remarks } \\
\hline & & & & & Top & Bottom & & \\
\hline BMI -24-1 & Tensile and fatigue & 600 & January, 1959 & $1.55 \times 10^{20}$ & -- & -- & BMI & $\begin{array}{l}\text { Examined at BMI Hot-Cell } \\
\text { Facility for melting }\end{array}$ \\
\hline BMI-24-2 & Tensile and fatigue & 120 & January, 1962 & $1.31 \times 10^{22}$ & $4.600 \times 10^{21}$ & $5.291 \times 10^{21}$ & $\begin{array}{l}\text { ETR } \\
\mathrm{K}-8-\mathrm{NE}\end{array}$ & Being irradiated \\
\hline BMI-24-3 & Tensile and fatigue & 600 & 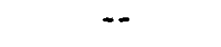 & -- & -- & -- & BMI & To be irradiated in the WTR \\
\hline BM1-24-4 & Tensile and fatigue & 120 & January, 1963 & $1.78 \times 10^{22}$ & $3.892 \times 10^{21}$ & $5.141 \times 10^{21}$ & $\begin{array}{l}\text { ETR } \\
\mathrm{K}-8-\mathrm{SE}\end{array}$ & Being irradiated \\
\hline BMI-24-6 & Tensile and fatigue & 120 & June, 1961 & $1.08 \times 10^{22}$ & $5.536 \times 10^{21}$ & $4.443 \times 10^{21}$ & $\begin{array}{l}\text { ETR } \\
K-8-N E\end{array}$ & Being irradiated \\
\hline BMI-24-8 & Tensile and fatigue & 120 & June, 1962 & $1.54 \times 10^{22}$ & $4.141 \times 10^{21}$ & $5.066 \times 10^{21}$ & $\begin{array}{l}\text { ETR } \\
\text { K-8-SE }\end{array}$ & Being irradiated \\
\hline BMI-24-10 & Tensile and fatigue & 120 & January, 1961 & $0.84 \times 10^{22}$ & $4.939 \times 10^{21}$ & $4.490 \times 10^{21}$ & $\begin{array}{l}\text { ETR } \\
\mathrm{K}-8-\mathrm{SE}\end{array}$ & Being irradiated \\
\hline BMI-24-11(c) & Tensile and fatigue & 600 & - & -- & -- & -- & BMI & Damaged at the ETR \\
\hline BMI -24-12 & Tensile and fatigue & 120 & June, 1960 & $0.61 \times 10^{22}$ & $6.154 \times 10^{21}$ & $5.659 \times 10^{21}$ & $\begin{array}{l}\text { ETR } \\
L-8-S E\end{array}$ & Being irradiated \\
\hline BMI-24-14 & Impact & 120 & May, 1960 & -- & $5.223 \times 10^{21}$ & 5. $298 \times 10^{21}$ & $\begin{array}{l}\text { ETR } \\
\text { K-8-NW }\end{array}$ & Being irradiated \\
\hline$B M I-24-15^{(d)}$ & Impact & 600 & -- & -- & $3.5 \times 10^{20}$ & $1.28 \times 10^{20}$ & $\begin{array}{l}\text { WTR } \\
\text { L-7-6 }\end{array}$ & Being irradiated in the WTR \\
\hline BMI-24-16 & Impact & 120 & June, 1960 & $0.61 \times 10^{22}$ & $5.271 \times 10^{21}$ & $4.521 \times 10^{21}$ & $\begin{array}{l}\text { ETR } \\
K-8-N W\end{array}$ & Being irradiated \\
\hline BMI $-24-17(c)$ & Tensile and fatigue & 600 & October, 1958 & $3.25 \times 10^{20}$ & - & -- & BMI & $\begin{array}{l}\text { Examined at BMI Hot-Cell } \\
\text { Facility after high tem- } \\
\text { perature observed }\end{array}$ \\
\hline
\end{tabular}


TABLE A-2. (Continued)

\begin{tabular}{|c|c|c|c|c|c|c|c|c|}
\hline \multirow[b]{2}{*}{ Capsule } & \multirow{2}{*}{$\begin{array}{l}\text { Type of Specimens } \\
\text { in Capsule }\end{array}$} & \multirow{2}{*}{$\begin{array}{c}\text { Proposed } \\
\text { Irradiation } \\
\text { Temperature, } \\
\text { F }\end{array}$} & \multirow{2}{*}{$\begin{array}{l}\text { Approximate } \\
\text { Removal } \\
\text { Date }^{(a)}\end{array}$} & \multirow{2}{*}{$\begin{array}{c}\text { Approximate Exposure } \\
\text { at Time of } \\
\text { Removal }^{(b)}, \text { nvt }\end{array}$} & \multicolumn{2}{|c|}{$\begin{array}{l}\text { Total Exposure as of } \\
\text { March } 28,1960, \text { nvt }\end{array}$} & \multirow[b]{2}{*}{ Location } & \multirow[b]{2}{*}{ Remarks } \\
\hline & & & & & Top & Bottom & & \\
\hline BMI $-24-18$ & Tensile and fatigue & 120 & -- & -- & $1.231 \times 10^{20}$ & $1.957 \times 10^{21}$ & $\begin{array}{l}\text { ETR } \\
K-8-N W\end{array}$ & $\begin{array}{l}\text { Being irradiated for postir- } \\
\text { radiation annealing studies }\end{array}$ \\
\hline $\mathrm{BMI}-24-19(\mathrm{c}, \mathrm{d})$ & Tensile and fatigue & 600 & -- & -- & $4.53 \times 10^{20}$ & $4.33 \times 10^{20}$ & $\begin{array}{l}\text { WTR } \\
L-7-6\end{array}$ & $\begin{array}{l}\text { Fabricated to replace } \\
\text { BMI-24-17; being irradiated } \\
\text { in the WTR }\end{array}$ \\
\hline BMI-24-20 & Tensile and fatigue & 120 & - & -- & $1.378 \times 10^{21}$ & $2.147 \times 10^{21}$ & $\begin{array}{l}\text { ETR } \\
K-8-N E\end{array}$ & $\begin{array}{l}\text { Being irradiated for postir- } \\
\text { radiation annealing studies }\end{array}$ \\
\hline BMI $-24-22$ & Tensile and fatigue & 120 & -- & -- & $1.769 \times 10^{21}$ & $2.463 \times 10^{21}$ & $\begin{array}{l}\text { ETR } \\
\text { L-8-SE }\end{array}$ & $\begin{array}{l}\text { Being irradiated for postir- } \\
\text { radiation annealing studies }\end{array}$ \\
\hline
\end{tabular}

(a) Based on 6-month lead on loop, plus 2 months for examination.

(b) Based on maximum fast flux at tube of $1.7 \times 10^{14} \mathrm{nv}$ for 6 -month periods.

(c) Thermocouple-lead capsule.

(d) Flux is reported as $>0.821 \mathrm{Mev}$; all other fluxes are $>1.0 \mathrm{Mev}$. 
There is considerable disagreement in some cases, as to the value of the instantaneous flux to be used in tabulating dosages on the surveillance capsules. Battelle has been continuously monitoring $\mathrm{K}-8$ positions in order to resolve the disagreement, but to date the results are inconclusive. A trend has been noted which casts doubt on the validity of flux values determined by dosimeters exposed for more than one cycle. For example, dosimeters exposed in Position K-8-W for three cycles, (Cycles 15, 16, and 17) indicated values of $1.12 \times 10^{14} \mathrm{nv}$, whereas single-cycle exposures during Cycles 13 , 22,23 , and 24 indicated values of $2.27,2.0,1.85$, and $2.1 \times 10^{14} \mathrm{nv}$, respectively. In discussions with Phillips Petroleum personnel, it was learned that this trend toward lower flux indications for multiple-cycle dosimeter exposures has been observed by other experimenters as well.

In order to determine more accurately the fast- and thermal-flux values in several positions of the ETR, Phillips personnel made extensive flux measurements during Cycle 27. In addition, a test to determine the ratio of the flux at the face of the 3 by 3-in. core-filler piece to that in the center of the experimental hole, was run. (Limited data from previous cycles indicate face fluxes are significantly less than the flux in the center of the hole, possibly because of the greater attenuation by surrounding metal as compared to that by water in the hole.) To clarify the flux measurements made by Phillips, an $\mathrm{N}_{\mathrm{L}}$ (1/100 full power) run of sufficient duration to activate both fast- and thermal-flux wires was made both at the beginning and at the end of the cycle. Fullcycle measurements were also taken to support the data from the $\mathrm{N}_{\mathrm{L}}$ runs. As mentioned previously, Phillips personnel are aware of the apparent fast-flux inaccuracies of multiple-cycle dosimeter wire exposures, and are including this parameter in their flux survey.

When the data from the above tests are complete, flux estimates and nvt accumulation on the BMI-24 series of capsules will be reviewed to make the estimates as accurate as possible. It is believed that the values quoted in Table A-2 are accurate within 20 per cent.

The two capsules being irradiated in the WTR, Capsules BMI-24-15 and BMI-2419, were inserted in Position L-8-5 in the WTR core for Cycle 1 on February 23, 1960, accumulating 690. $2 \mathrm{MWD}$ before shutdown on March 13. Early in the second cycle, the reactor sustained a fuel-element rupture and was closed down for repair. No neutron accumulation was received during April and none is expected during May. It is possible that a 10-day escallation from 40 to 60 megawatts will occur in June, to be followed by a 10-day 60-megawatt run.

\section{Development of High-Strength Niobium-Base Alloys}

J. A. DeMastry, F. R. Shober, and R. F. Dickerson

Operation of the EBR-II, a sodium-cooled fast reactor, at temperatures in the range of 650 to $1000 \mathrm{C}$ requires development of a new cladding material. Stainless steel forms a eutectic with uranium at $725 \mathrm{C}$, thus making it incompatible with uranium in this temperature range. High strength at elevated temperatures and the absence of a lowmelting uranium-niobium eutectic make niobium-base alloys attractive for this cladding application. 
An investigation recently concluded at Battelle (BMI-1417) disclosed that both chromium and zirconium are potent strengtheners of niobium at 650 and $800 \mathrm{C}$. Other studies have shown that vanadium is also a good strengthener of niobium. The strengthening of niobium by the addition of chromium, vanadium, or zirconium appears to be due to solid-solution hardening. Although the high melting points of these elements would indicate that niobium alloys containing them should retain their strength well above $1000 \mathrm{C}$, experimental studies are needed to establish the degree of the strength retained. Previous work indicates that niobium alloys in the systems mentioned above can probabl: be fabricated at 500 to $600 \mathrm{C}$ by forging; and finished sheet material can be prepared by subsequent cold rolling.

Based on the data obtained from the program recently concluded, alloys of the following compositions will be prepared: niobium-2. $0 \mathrm{w} / 0 \mathrm{chromium}$, niobium-5. $3 \mathrm{w} / \mathrm{o}$ vanadium, niobium-3.0 w/o zirconium, and niobium- $2.0 \mathrm{w} / 0$ zirconium- $1.0 \mathrm{w} / 0 \mathrm{chro-}$ mium. As the investigation progresses, additional alloys may be prepared. Heats weighing 5 to $6 \mathrm{lb}$ will be prepared by consumable-electrode arc melting of the abovementioned alloys. These ingots will be forged at 500 to $600 \mathrm{C}$ and cold rolled to sheet material for property determinations.

The recrystallization temperature (parameters; I-hour anneal, 95 per cent cold work) will be determined for all alloys being investigated. All mechanical and physical properties will be determined on annealed material. The tensile strength of all alloys will be determined at 650,800 , and $1000 \mathrm{C}$. Creep tests are to be performed also at 650,800 , and $1000 \mathrm{C}$. The thermal conductivity and thermal expansion of each alloy will be investigated in the temperature range from room temperature to $1000 \mathrm{C}$.

A number of specimens prepared during the previous program are being tensile tested in the cold-worked condition at $1000 \mathrm{C}$. As soon as a suitable annealing temperature has been established, these alloys will also be tensile tested in the annealed condition. The alloys being tested are listed below:

\author{
Niobium (unalloyed) \\ Niobium-1. $08 \mathrm{w} / \mathrm{o}$ chromium \\ Niobium-1. 29 w/o chromium \\ Niobium-1.84 w/o chromium \\ Niobium-3.21 w/o chromium \\ Niobium-2. $74 \mathrm{w} / \mathrm{o}$ zirconium \\ Niobium-3. $34 \mathrm{w} / \mathrm{o}$ zirconium \\ Niobium-4. $33 \mathrm{w} / \mathrm{o}$ zirconium \\ Niobium-20.5 w/o titanium- $4.28 \mathrm{w} / 0$ chromium
}

A study to determine the recrystallization temperature of the se alloys is under way. Specimens of each alloy have been annealed at 1200, 1260, 1315, and 1370 C for $1 \mathrm{hr}$ and furnace cooled. Hardness measurements will be used to roughly outline the recrystallization temperature; this determination will be supplemented with metallography. 
Development of Corrosion-Resistant Niobium Alloys D. J. Maykuth, W. D. Klopp, R. I. Jaffee, W. E. Berry,
and F. W. Fink

Corrosion studies are being continued in the program to develop a high-strength low-cross section corrosion-resistant niobium alloy for pressurized-water-reactor applications. An additional 28 days of exposure to high-temperature water and steam has been obtained on alloy specimens. A complete listing of the alloys under evaluation was presented in BMI-1430. Mechanical-property evaluations have been completed. A report on all phases of the program is now in rough-draft form.

Weight-change data for exposure times ranging up to 392 days in 600 and $680 \mathrm{~F}$ water and $750 \mathrm{~F}$ 1500-psi steam have been obtained. Based on low weight gain and tightly adherent corrosion films, the data continue to indicate that the most resistant alloys are those which contain about 45 a/o zirconium and a ternary containing 28 a/o titanium- 6 a/o chromium. However, a 12.5 a/o vanadium alloy possesses the optimum combination of high strength, low neutron absorption, and promising corrosion resistance. The data also continue to indicate that the corrosion resistance of niobium alloys is unaffected by small amounts of interstitials, whether they are added to the alloy or are present in the niobium melting stock.

Corrosion testing of the alloys under evaluation will be continued.

Investigation of the Creep Properties of Zircaloy-2 During Irradiation at Elevated Temperatures

F. R. Shober, P. B. Shumaker, A. P. Young, and M. F. Amateau

An in-pile creep experiment has been designed and an instrumented capsule is being constructed to study the in-reactor creep properties of Zircaloy-2 at $650 \mathrm{~F}$. A comparison is to be made between the in-reactor and the out-of-reactor properties to determine the effect of a fast-neutron flux on creep properties. Evidence of strain aging in Zircaloy-2 and its related mechanisms are also being investigated using short-time tensile tests, metallography, and internal-friction tests.

The capsule to contain the in-pile creep experiment has been designed, and progress toward its construction may be described as follows:

(1) All capsule components, except the specimens and the heater blocks, have been fabricated and are ready for assembly. Cast-iron molds for the heater blocks are on hand, and the heater-casting operations can proceed as soon as the heaters are available.

(2) X-ray inspections of the heaters which arrived early in April indicated that the element and lead-out wires had been joined by a condenser-discharge lap-weld technique. Since Heliarc butt-welded joints are considered a requirement and were specified in the original 
order, most of the heaters were returned to the manufacturer. A few of the better units were retained and will be used in the thermalmock-up experiment. The manufacturer has agreed to replace the unacceptable heaters with units having the specified joints.

(3) A pressure mock-up of the capsule was run; the outside shell and heaters were subjected to internal fluid pressures up to $1000 \mathrm{psi}$ without incident. However, data from strain gages located in questionable areas have not yet been translated into stress levels.

(4) Engineering analysis of the capsule design has been completed, and copies have been sent to the appropriate WTR project engineer for presentation to the Reactor Safeguards Committee. Comprehensive treatments of heat transfer and stress, as well as discussions of out-of-pile temperature and pressure-control devices, were included.

During May, a the rmal mock-up of the capsule will be assembled. Studies with this capsule will be used to check the theoretical heat-transfer analysis. Heaters considered unsuitable for the reactor experiment will be used in this capsule.

The presence of yield point during tensile testing after straining and aging at test temperatures of $80,450,550$, and $650 \mathrm{~F}$ is thought to be evidence of strain aging in Zircaloy-2. Internal-friction studies are being made to augment the tensile testing with attempts made to relate the yield-point phenomenon with the diffusion of either a solute or interstitial atoms to dislocation sites. During the past work period, internal-friction measurements were made on 0.5 per cent strained Zircaloy- 2 in the temperature range 185 to $750 \mathrm{~F}$. Measurements were made at intervals up to $300 \mathrm{~min}$ after straining. These data when plotted as log internal friction versus $10 \mathrm{~g}$ time show two distinct sets of curves. A set of linear curves representing data obtained from 570 to $750 \mathrm{~F}$ tests and set of nonlinear curves representing data obtained from 50 to $300 \mathrm{~F}$ tests were evident from the plot. The low-temperature or nonlinear curves indicate a greater rate of energy dissipation during the early period of recovery than do the higher temperature curves. It is entirely possible that this greater decrease in internal friction is the sum of the Köster effect and additional energy lost because of strain aging. Attempts will be made to define more precisely the temperature at which this extra energy loss becomes evident.

Work pertaining to the preparation of thin films of zirconium and Zircaloy- 2 has been confined to construction of apparatus. Study of the deformation processes of Zircaloy will be made using tensile specimens with flat gage sections. Replicas will be made from this flat surface at predetermined amounts of deformation for study with the electron microscope. Studies will be made of annealed materials and of material that has exhibited evidences of aging. 
Determination of Oxygen in Sodium at

Concentrations Below 10 PPM

D. R. Grieser, E. H. Hall, and W. H. Goldthwaite

New approaches to the measurement of oxygen in sodium are being studied. The objective is to demonstrate the feasibility of determining the oxygen concentration below $10 \mathrm{ppm}$ with a sensitivity of $\pm 1 \mathrm{ppm}$.

The study, at present, is being concentrated on an evaluation of a mass spectrometric technique. The study of the vaporization of sodium monoxide in the mass spectrometer has been continued, with emphasis on materials suitable for the construction of the vaporization oven. This material must be nonreactive with both oxygen and sodium under the conditions prevailing in the mass spectrometer. Two runs were made with a nickel oven. An oxygen peak was not observed in either case.

A platinum oven is being designed for the next experiment, and consideration is being given to some of the oxides, e.g. , thoria and alumina, which have been reported to be stable toward sodium.

Wear and Friction of Sliding Surfaces in Liquid Sodium

Friction and wear between various combinations of metallic specimens sliding in liquid sodium are being studied. The sliding specimens consist of a ball sliding transversely across a flat specimen, under the following conditions: dry surfaces, sodium lubricated surfaces, and dry surfaces containing known oxide films. For each of these conditions data are obtained throughout a temperature range up to $1300 \mathrm{~F}$. Specimen wear resulting from the various rubbing experiments has been qualitatively evaluated by light and electron microscopy.

Failure of the sodium-loading component in the friction apparatus has necessitated modification of equipment and caused temporary suspension of friction experiments. These experiments will be started again in May.

Investigations of molybdenum-base films have continued. A film of $\mathrm{MoO}_{2}$ was produced on a steel specimen surface by reducing, in hydrogen at $900 \mathrm{C}$, a previously applied film of $\mathrm{MoO}_{3}$. This reduction did not occur when the same experiment was performed at $400 \mathrm{C}$. The optimum temperature for initiation of the reduction reaction appears to fall between 400 and $900 \mathrm{C}$. The $\mathrm{MoO}_{2}$ so produced separated from the molybdenum metal during the vacuum-evaporation step which followed. This latter procedure was used to deposit $\mathrm{MoO}_{2}$ on a polished stainless steel specimen surface. Electron-diffraction analysis of this deposited layer showed it to be amorphous and, unfortunately, unstable in air. Consequently, other methods will be tried for depositing $\mathrm{MoO}_{2}$ onto the test surface. An attempt to vapor deposit $\mathrm{Na}_{2} \mathrm{MoO}_{4}$ is also under way.

Electron-diffraction studies of the films formed on tungsten surfaces are also in progress. Any alteration in composition of these films, due to the varying environmental conditions of the friction tests, will also be noted. Friction experiments involving sodium-lubricated stainless steel specimens will be concluded as soon as feasible. 
$A-\underline{12}$

The results will be compared with those which will be obtained for $\mathrm{MoO}_{2}-$ and $\mathrm{Na}_{2} \mathrm{MoO}_{4}^{-}$ coated stainless steel. 
STUDIES OF FUEL ALLOYS (AEC-DRD)

R. F. Dickerson

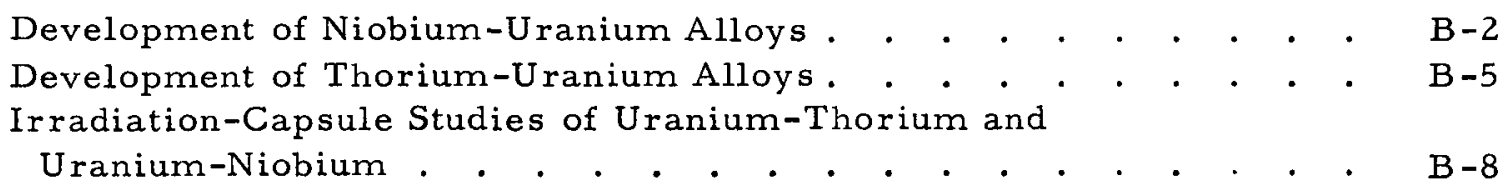

After an exposure of 280 days in $600 \mathrm{~F}$ water, a niobium-20 w/o uranium alloy is still gaining weight, whereas niobium-base binary alloys containing $10,30,40,50$, and $60 \mathrm{w} / \mathrm{o}$ uranium are losing weight. The data to date indicate that the higher the oxygen content of the alloys the more severe the corrosion attack. Alloys containing $40 \mathrm{w} / 0$ or more uranium exhibit more rapid weight gain in $1500 \mathrm{~F}$ sodium than do the alloys of lower uranium content. Contrary to expectations, oxygen contamination does increase the tensile strength of the alloys at elevated temperatures. Data from the first phase of a recrystallization study performed on alloys cold worked 80 per cent and annealed for $1 \mathrm{hr}$ have been evaluated. In all cases, recrystallization occurred below $2080 \mathrm{~F}$. Coefficients of linear expansion have been determined, and electrical-resistivity and thermal-conductivity measurements are being made over the same temperature range.

Thorium nitride of stoichiometric composition has been prepared by arc melting. Analysis has shown that a trace of copper and 1 w/o tungsten were introduced during arc melting and that $\mathrm{ThO}_{2}$ in amounts greater than 1 w/o was also present. Melting studies designed to develop the best method of preparing thorium-uranium alloys with ideal uranium distribution are being performed, and creep tests are in progress.

In order that the niobium-uranium and thorium-uranium alloys may be irradiation tested, a test program has been planned, and necessary capsule design is in progress. These double-wall capsules will contain 15 specimens and will be temperature controlled and monitored. Further temperature control will be obtained by changing the thermal conductance of the inert-gas-filled annulus during operation by manual regulation. 
The fabrication characteristics, mechanical and physical properties, irradiation stability, and corrosion behavior in various environments of niobium-uranium alloys are being studied to determine the applicability of these alloys as reactor fuels.

Alloys containing from 10 to $60 \mathrm{w} / 0$ uranium were prepared for study from three grades of niobium containing from 0.03 to $0.07 \mathrm{w} / \mathrm{o}$ oxygen and 0.02 to $0.74 \mathrm{w} / \mathrm{o}$ zirconium. No significant effects on properties due to differences in oxygen or zirconium in the base materials were noted.

Specimens of all of the niobium-uranium alloys being studied have been corrosion tested in $600 \mathrm{~F}$ water for a total of 280 days. Data are shown in Table B-1. The majority of the alloys being tested are now losing weight; however, the niobium-20 w/o uranium alloy is still gaining weight. This alloy has performed best in all corrosion testing to date. Examination of the data indicates that oxygen content has an effect on the degree of attack by $600 \mathrm{~F}$ water, samples with higher oxygen contents being attacke more severely. Further exposure should establish the nature of the trend in all of the alloys being tested.

Alloys being exposed to sodium at $1500 \mathrm{~F}$ have been examined after $100 \mathrm{hr}$ of exposure. The alloys all exhibit a dull-black oxide. However, alloys containing $40 \mathrm{w} / \mathrm{c}$ or more uranium are gaining weight much faster than alloys containing smaller amount: of uranium, as seen in Table B-2. There is no apparent effect of the high oxygen content in the niobium-10 w/o uranium alloys upon corrosion behavior in sodium. All specimens have been returned to test and will be examined after an additional $500 \mathrm{hr}$ of exposure.

The tensile properties of cold-worked niobium-10 w/o uranium and niobium-20 w/o uranium alloys were determined at 1800 and $2000 \mathrm{~F}$. Previous work had yielded a spread of values (from 23,000 to $40,000 \mathrm{psi}$ ) for the ultimate tensile strength at $2200 \mathrm{~F}$. Examination of the specimens revealed that they had been contaminated by oxygen during testing. In general, it has been believed that oxygen contamination does not appreciably increase the tensile strength of alloys at elevated temperatures. The results obtained so far in this study indicate that oxygen does have a great strengthening effect on niobium-base alloys at 1800, 2000, and $2200 \mathrm{~F}$. Table B-3 lists tensile data for a niobium-10 w/o uranium alloy which contains 3100 ppm oxygen and a niobium-20 w/o uranium alloy containing $200 \mathrm{ppm}$ oxygen. As can be seen, the test results show that the $10 \mathrm{w} / 0$ uranium alloy is as strong as the $20 \mathrm{w} / 0$ uranium alloy. This is contrary to findings which show that the strength of niobium-uranium alloys increases with increasing uranium content. The ductility (elongation) readings obtained indicate that the alloy containing $10 \mathrm{w} / \mathrm{o}$ uranium is much less ductile than might be expected for such an alloy. This lowering of ductility is typical of the effect of oxygen upon many cubic metals. Additional specimens will be examined at lower temperatures, 800 and $1300 \mathrm{~F}$, to determine the temperature limits for the strengthening effect of oxygen and to learn if a "blue-brittle range" exists for these alloys. 
TABLE B-1. CORROSION DATA FOR NIOBIUM-URANIUM ALLOYS(a) IN 600 F WATER

\begin{tabular}{|c|c|c|c|c|c|}
\hline \multirow{2}{*}{$\begin{array}{c}\text { Nominal Alloy } \\
\text { Content } \\
\text { (Balance Niobium), } \\
\text { w/o } \\
\end{array}$} & \multicolumn{2}{|c|}{ Impurity Content } & \multirow{2}{*}{$\begin{array}{l}\text { Specimen } \\
\text { Condition }\end{array}$} & \multicolumn{2}{|c|}{$\begin{array}{c}\text { Total Weight Change } \\
\text { in } 600 \mathrm{~F} \text { Water in } \\
266 \text { and } 280 \text { Days, } \\
\text { mg per } \mathrm{cm}^{2}\end{array}$} \\
\hline & Oxygen $(\mathrm{b}), \mathrm{ppm}$ & Zirconium(c), w/o & & 266 Days & 280 Days \\
\hline \multirow[t]{3}{*}{$10 \mathrm{U}$} & 680 & 0.74 & Fabricated & 0.60 & 0.61 \\
\hline & 1190 & 0.17 & Ditto & -3.15 & -3.45 \\
\hline & 3170 & 0.02 & Dit to & -4.75 & -5.03 \\
\hline \multirow[t]{3}{*}{$20 \mathrm{U}$} & 458 & 0.74 & Ditto & 0.93 & 0.92 \\
\hline & 523 & 0.17 & Ditto & 1.96 & 1.99 \\
\hline & 198 & 0.02 & Ditto & 0.73 & 0.73 \\
\hline \multirow[t]{3}{*}{$30 \mathrm{U}$} & 586 & 0.74 & As cast & -0.33 & -0.41 \\
\hline & 669 & 0.17 & Fabricated & -2.87 & -2.78 \\
\hline & 165 & 0.02 & As cast & -1.26 & -1.61 \\
\hline \multirow[t]{3}{*}{$40 \mathrm{U}$} & 661 & 0.74 & As cast & 0.37 & 0.63 \\
\hline & 579 & 0.17 & Ditto & 0.08 & 0.03 \\
\hline & 261 & 0.02 & Ditto & 0.57 & 0.53 \\
\hline \multirow[t]{3}{*}{$50 \mathrm{U}$} & 375 & 0.74 & Ditto & -0.37 & -0.53 \\
\hline & 334 & 0.17 & Ditto & 0.10 & -0.06 \\
\hline & 271 & 0.02 & Ditto & -1.10 & -1.45 \\
\hline \multirow[t]{3}{*}{$60 \mathrm{U}$} & 471 & 0.74 & Ditto & -8.38 & -8.76 \\
\hline & 273 & 0.17 & Ditto & -6.92 & -7.34 \\
\hline & 192 & 0.02 & Ditto & -2.53 & -2.75 \\
\hline Zircaloy-2 & -- & -. & - & 0.25 & 0.28 \\
\hline
\end{tabular}

(a) Average of two specimens.

(b) Analyzed values.

(c) Nominal composition. 
TABLE B-2. CORROSION DATA FOR NIOBIUM-URANIUM ALLOYS(a) EXPOSED IN SODIUM AT $1500 \mathrm{~F}$

\begin{tabular}{|c|c|c|c|c|}
\hline \multirow{2}{*}{$\begin{array}{c}\text { Nominal Alloy } \\
\text { Content } \\
\text { (Balance Nıbium), } \\
\text { w/o }\end{array}$} & \multicolumn{2}{|c|}{ Impunty Content } & \multirow{2}{*}{$\begin{array}{l}\text { Specimen } \\
\text { Condition }\end{array}$} & \multirow{2}{*}{$\begin{array}{l}\text { Total Weight Change in } \\
1500 \mathrm{~F} \text { Sodium After } \\
1000 \mathrm{Hr} \text {, mg per } \mathrm{cm}^{2}\end{array}$} \\
\hline & Oxygen ${ }^{(5)}$,ppm & Zirconium $^{(c)}, w / o$ & & \\
\hline \multirow[t]{3}{*}{$10 \mathrm{U}$} & 680 & 0.74 & Fabricated & -0.06 \\
\hline & 1190 & 0.17 & Ditto & 0.07 \\
\hline & 3170 & 0.02 & Ditto & -0.41 \\
\hline \multirow[t]{3}{*}{$20 \mathrm{U}$} & 458 & 0.74 & Ditto & -0.30 \\
\hline & 523 & 0.17 & Ditto & 0.52 \\
\hline & 198 & 0.02 & Ditto & 0.10 \\
\hline $30 \mathrm{U}$ & 165 & 0.02 & As cast & 0.89 \\
\hline $40 \mathrm{U}$ & 261 & 0.02 & As cast & 1.78 \\
\hline $50 \mathrm{U}$ & 271 & 0.02 & As cast & 1.23 \\
\hline $60 \mathrm{U}$ & 192 & 0.02 & As cast & 3.32 \\
\hline
\end{tabular}

(a) Average of two specimens

(b) Analyzed values.

(c) Nominal values.

TABLE B-3. SHORT-TIME TENSILE PROPERTIES OF NIOBIUM-URANIUM ALLOYS

\begin{tabular}{|c|c|c|c|c|}
\hline $\begin{array}{c}\text { Alloy Content } \\
\text { (Balance Nlobium), } \\
\text { w/o }\end{array}$ & $\begin{array}{l}\text { Test Temperature, } \\
\text { F }\end{array}$ & $\begin{array}{l}0.2 \text { Per Cent } \\
\text { Offset Yleld } \\
\text { Strength, psl }\end{array}$ & $\begin{array}{l}\text { Ultumate Tensıle } \\
\text { Strength, psı }\end{array}$ & $\begin{array}{c}\text { Elongation in } 1 \text {-In. Gage } \\
\text { Length, per cent }\end{array}$ \\
\hline $10 \mathrm{U}+031 \mathrm{O}$ & 1800 & 44,600 & 52,500 & 4.0 \\
\hline $10 \mathrm{U}+031 \mathrm{O}$ & 2000 & 25400 & 35,300 & 9.0 \\
\hline $10 \mathrm{U}+0.310$ & 2200 & -- & 24,000 & 10.0 \\
\hline $20 \mathrm{U}+0.02 \mathrm{O}$ & 1800 & 43,000 & 52,000 & 34.0 \\
\hline $20 \mathrm{U}+0.02 \mathrm{O}$ & 2000 & 28,600 & 37,500 & 740 \\
\hline
\end{tabular}


Creep tests to determine the minimum creep rates of both the niobium-10 and $-20 \mathrm{w} / \mathrm{o}$ uranium alloys at $1600 \mathrm{~F}$ are being conducted. At present no results have been obtained. One specimen of niobium-10 w/o uranium alloy has been on test for $110 \mathrm{hr}$ under a stress of $20,000 \mathrm{psi}$.

The first phase of a study to determine the recrystallization temperature for material cold worked 80 per cent and annealed for $1 \mathrm{hr}$ has been completed. Table B-4 shows the results of annealing at $2080,2180,2280$, and $2380 \mathrm{~F}$. These results indicate that recrystallization occurs in $1 \mathrm{hr}$ at a temperature below $2080 \mathrm{~F}$. Anneals at 1800, 1900 , and $2000 \mathrm{~F}$ will be started.

The coefficients of linear thermal expansion of niobium-10 and $-20 \mathrm{w} / \mathrm{o}$ uranium alloys have been determined from 68 to $1800 \mathrm{~F}$ and are shown in Table B-5. Only a moderate deviation from a linear expansion with temperature is indicated. Electricalresistivity and thermal-conductivity measurements are being made over the same temperature range and should be completed soon.

A study of the effects of oxygen on the composition limits of the gamma immiscibility loop in the niobium-uranium-alloy system is in progress. Heat treatments of uranium alloys containing 20 to $58 \mathrm{w} / 0$ niobium with different oxygen contents are nearly completed. Specimens have been submitted for gas analyses by vacuum-fusion techniques to determine the actual oxygen concentrations in the alloys. The alloys will be examined metallographically after heat treating. The effect of zirconium on the niobium-uranium immiscibility loop is also being investigated. Ternary uraniumniobium-zirconium alloys with 50 and 60 w/o uranium are being heat treated at temperatures of 500,650 , and $750 \mathrm{C}$ as part of this study.

In an attempt to improve the fabricability of the niobium alloys containing more than $20 \mathrm{w} / 0$ uranium, two alloys were prepared with ternary additions of $10 \mathrm{w} / 0$ zirconium. These ingots (niobium-30 w/o uranium-10 w/o zirconium and niobium -40 w/o uranium-10 w/o zirconium) were cut into 1 -in. -thick wafers and canned in molybdenum tubes. Fabrication of these capsules was attempted at both 2400 and $2800 \mathrm{~F}$. The results of fabrication are shown in Table B-6. The alloys fabricated at $2400 \mathrm{~F}$ appear to be better than those fabricated at $2800 \mathrm{~F}$. This may be due to "hot shortness' in these alloys. The addition of zirconium appears to have made the alloy containing $40 \mathrm{w} / \mathrm{o}$ uranium more fabricable. Additional ingots containing $20 \mathrm{w} / \mathrm{o}$ zirconium and 30 and $40 \mathrm{w} / 0$ uranium will be prepared for further fabrication studies. The slab material fabricated above will be surface conditioned to remove cracks and rolled to sheet for property determinations.

\section{Development of Thorium-Uranium Alloys}

M. S. Farkas, R. W. Endebrock, A. A. Bauer, and R. F. Dickerson

Thorium-uranium and thorium-uranium-base alloys are being investigated with the aim of improving their irradiation stability. The effect of process variables on the size and distribution of uranium particles is being studied. Alloys being investigated are thorium-uranium with additions of molybdenum, niobium, and zirconium, and zirconium in conjunction with niobium. The preparation and properties of thorium and thorium-uranium carbides and nitrides are also being studied. 
TABLE B-4. RESULTS OF PRELIMINARY RECRYSTALLIZATION-TEMPERATURE DETERMINATIONS ON ALLOYS COLD WORKED 80 PER CENT AND ANNEALED 1 HR

\begin{tabular}{|c|c|c|c|c|c|}
\hline \multirow{2}{*}{$\begin{array}{c}\text { Alloy Composition } \\
\text { (Balance Niobium), } \\
\text { w/o }\end{array}$} & \multicolumn{5}{|c|}{ Knoop Hardness Measurements (200-G Load) } \\
\hline & Cold Worked & $2080 \mathrm{~F}$ & $2180 \mathrm{~F}$ & $2280 \mathrm{~F}$ & $2380 \mathrm{~F}$ \\
\hline $10 \mathrm{U}$ & 247 & 190 & 185 & 194 & 184 \\
\hline $20 \mathrm{U}$ & 278 & 239 & 206 & 227 & 219 \\
\hline $30 \mathrm{U}$ & 327 & 227 & 218 & 223 & 228 \\
\hline
\end{tabular}

TABLE B-5. MEAN LINEAR THERMAL-EXPANSION COEFFICIENTS FOR NIOBIUM-10 AND -20 W/O URANIUM ALLOYS

\begin{tabular}{|c|c|c|c|c|c|c|c|c|}
\hline \multirow{4}{*}{$\begin{array}{c}\text { Temperature } \\
\text { Range, } \\
\text { F } \\
\end{array}$} & \multicolumn{8}{|c|}{ Thermal-Expansion Coefficient, $10^{-6}$ per $F$} \\
\hline & \multicolumn{4}{|c|}{ Niobium -10 w/o Uranium } & \multicolumn{4}{|c|}{ Niobium $-20 \mathrm{w} / \mathrm{o}$ Uranium } \\
\hline & \multicolumn{2}{|c|}{$\begin{array}{c}\text { First Thermal } \\
\text { Cycle } \\
\end{array}$} & \multicolumn{2}{|c|}{$\begin{array}{c}\text { Second Thermal } \\
\text { Cycle } \\
\end{array}$} & \multicolumn{2}{|c|}{$\begin{array}{c}\text { First Thermal } \\
\text { Cycle } \\
\end{array}$} & \multicolumn{2}{|c|}{$\begin{array}{c}\text { Second Thermal } \\
\text { Cycle }\end{array}$} \\
\hline & Heating & Cooling & Heating & Cooling & Heating & Cooling & Heating & Cooling \\
\hline $68-200$ & 4.1 & 4.1 & 4.1 & 4.2 & 4.2 & 4.3 & 4.0 & 4.1 \\
\hline $200-400$ & 4.1 & 4.2 & 4.2 & 4.3 & 4.4 & 4.4 & 4.2 & 4.2 \\
\hline $400-600$ & 4.3 & 4.4 & 4.5 & 4.5 & 4.6 & 4.6 & 4.5 & 4.6 \\
\hline $600-800$ & 4.5 & 4.6 & 4.6 & 4.7 & 4.7 & 4.8 & 4.8 & 4.8 \\
\hline $800-1000$ & 4.8 & 4.9 & 4.8 & 4.8 & 5.0 & 5.0 & 4.9 & 5.1 \\
\hline $1000-1200$ & 4.9 & 4.9 & 4.9 & 5.0 & 5.1 & 5.1 & 5.2 & 5.1 \\
\hline $1200-1400$ & 5.0 & 4.9 & 5.0 & 5.0 & 5.3 & 5.2 & 5.4 & 5.3 \\
\hline $1400-1600$ & 5.2 & 5.2 & 5.0 & 5.1 & 5.5 & 5.4 & 5.4 & 5.3 \\
\hline $1600-1800$ & 5.2 & 5.2 & 5.3 & 5.4 & 5.7 & 5.8 & 5.6 & 5.5 \\
\hline $68-1800$ & 4.7 & 4.7 & 4.7 & 4.8 & 5.0 & 5.0 & 4.9 & 4.9 \\
\hline
\end{tabular}


TABLE B-6. RESULTS OF FABRICATION $\left({ }^{(a)}\right.$ OF NIOBIUM-URANIUM AND NIOBIUM-URANIUM-ZIRCONIUM ALLOYS

\begin{tabular}{|c|c|c|c|c|}
\hline $\begin{array}{c}\text { Alloy Composition } \\
\text { (Balance Niobium), } \\
\text { w/o }\end{array}$ & $\begin{array}{c}\text { Temperature of } \\
\text { Fabrication, } \\
\text { F }\end{array}$ & $\begin{array}{c}\text { Type of } \\
\text { Fabrication }\end{array}$ & $\begin{array}{l}\text { Reduction } \\
\text { in Area, } \\
\text { per cent }\end{array}$ & Remarks \\
\hline $30 \mathrm{U}-10 \mathrm{Zr}$ & 2400 & Upset forged & 50 & $\begin{array}{l}\text { Slab in two pieces; material appears } \\
\text { sound otherwise }\end{array}$ \\
\hline $40 \mathrm{U}-10 \mathrm{Zr}$ & 2400 & Upset forged & 50 & $\begin{array}{l}\text { Slab in one piece; edge cracks; radiograp } \\
\text { shows slab to be sound }\end{array}$ \\
\hline $40 \mathrm{U}$ & 2800 & Upset forged & 40 & $\begin{array}{l}\text { Slab in one piece; edge cracks present; } \\
\text { slab appears sound }\end{array}$ \\
\hline \multirow[t]{2}{*}{$30 \mathrm{U}-10 \mathrm{Zr}$} & 2800 & Upset forged & 50 & $\begin{array}{l}\text { Surface cracks; slab fractured into three } \\
\text { pieces }\end{array}$ \\
\hline & 2800 & Rolled & 70 & Surface cracks; edge cracks \\
\hline \multirow[t]{2}{*}{$40 \mathrm{U}-10 \mathrm{Zr}$} & 2800 & Upset forged & 50 & Slab fractured into three pieces \\
\hline & 2800 & Rolled & 70 & Severe surface cracks \\
\hline
\end{tabular}

(a) Alloys were encased in evacuated molybdenum cans. 
Arc-melted specimens of $\mathrm{ThN}$ that were prepared by three and six melting passes of thorium under $2-1 / 2 \mathrm{~atm}$ of nitrogen contained 5.38 and $5.02 \mathrm{w} / 0$ nitrogen, respectively. The stoichiometric nitrogen content of $\mathrm{ThN}$ is $5.69 \mathrm{w} / \mathrm{o}$. Since the thermodynamics of the reaction indicate that the above melting conditions should be adequate to produce stoichiometric ThN, an investigation was made to determine the cause of the low nitrogen content in the arc-melted specimens. Metallographic examination indicated that in addition to ThN, a second, unknown phase was present. Chemical analyses show that about $1 \mathrm{w} / \mathrm{o}$ tungsten and trace of copper were present in the ThN specimens. These contaminants were introduced during the arc-melting process from the tungsten-tip electrode and the copper hearth. Also, an HCL-insolubles analysis showed that a contaminant, probably $\mathrm{ThO}_{2}$, was present in amounts greater than $1 \mathrm{w} / \mathrm{o}$. Making allowances for the above-mentioned contaminants, calculation of the nitrogen content of the remaining thorium shows that the stoichiometric ThN composition was closely approached.

The following thorium-uranium alloys were prepared as 3-1b melts in a vacuuminduction furnace for an investigation of the effect of melting procedure on uranium homogeneity and particle size:

(1) Thorium-10 w/o uranium

(2) Thorium-10 w/o uranium-2 w/o niobium

(3) Thorium-10 w/o uranium-1.5 w/o molybdenum

(4) Thorium-10 w/o uranium-10 w/o zirconium.

The melts were held at $1900 \mathrm{C}$ under a vacuum of $1 \times 10^{-3} \mathrm{~mm}$ of mercury and stirred electromagnetically for 2 min prior to pouring into a 1 -in.-diameter copper mold. Specimens taken from the top and bottom of ingots will be examined metallographically and analyzed chemically for uranium distribution.

Results of creep tests conducted at $700 \mathrm{C}$ are presented in Table B-7. Data for thorium-10 w/o uranium-10 w/o zirconium and thorium-10 w/o uranium-10 w/o zirconium-2 w/o niobium alloys will also be obtained; preliminary results for the latter alloy indicate that its creep resistance is considerably lower than that of the thorium-20 $\mathrm{w} / 0$ uranium alloy at $700 \mathrm{C}$. Hot-hardness tests of a thorium-10 w/o uranium-0.1 w/o beryllium alloy indicate good high-temperature strength; consequently 600 and $700 \mathrm{C}$ creep and tensile tests will be conducted on this alloy.

Irradiation-Capsule Studies of Uranium-Thorium and Uranium-Niobium

D. B. Hamilton, J. H. Stang, and E. M. Simons

An irradiation program has been initiated to investigate the effects of irradiation on uranium-niobium and uranium-thorium fuel alloys. A total of four temperaturecontrolled capsules are planned for irradiation in the Westinghouse Testing Reactor; each of the capsules will contain 15 small cylindrical specimens. The uranium-niobium pins will include niobium-10, $-20,-30 \mathrm{w} / \mathrm{o}$ uranium alloys and two niobium-zirconiumuranium alloys. The uranium-thorium pins will be thorium-5 to -25 w/o uranium 
TABLE B-7. CREEP DATA OBT AINED FROM ANNEALED THORIUMURANIUM-BASE ALLOYS AT $700 \mathrm{C}$

\begin{tabular}{lc}
\hline $\begin{array}{c}\text { Composition } \\
\text { (Balance Thorium), w/o }\end{array}$ & $\begin{array}{c}\text { Stress Required for Creep Rate of } 0.01 \\
\text { Per Cent per Hr, psi }\end{array}$ \\
\hline 5 uranium & 1700 \\
10 uranium-1.5 molybdenum & 1600 \\
10 uranium-2 niobium & 1200 \\
10 uranium & 1100 \\
20 uranium & 480 \\
\hline
\end{tabular}

TABLE B-8. SUMMARY OF DESIRED IRRADIATION CONDITIONS FOR CAPSULES CONTAINING SPECIMENS OF URANIUM-NIOBIUM AND URANIUM-THORIUM

\begin{tabular}{|c|c|c|}
\hline & $\begin{array}{c}\text { Uranium-Niobium } \\
\text { Units } \\
\end{array}$ & $\begin{array}{c}\text { Uranium-Thorium } \\
\text { Units } \\
\end{array}$ \\
\hline Number of Capsules & 2 & 2 \\
\hline Specimen Center-Line Temperature, $\mathbf{F}$ & 1600 and 1800 & 1200 and 1380 \\
\hline \multicolumn{3}{|l|}{ Specimen Burnup, } \\
\hline Total, w/o & 1 & 1 \\
\hline Uranium-235, a/o & 25 & 11 \\
\hline $\begin{array}{l}\text { Expected Unperturbed Thermal-Neutron } \\
10^{14} \mathrm{nV}\end{array}$ & 1.2 & 1.2 \\
\hline \multicolumn{3}{|l|}{ Expected Fission-Heat Generation Rate Per } \\
\hline Specimen(a), Btu per hr & 1800 & 2040 \\
\hline Expected In-Pile Time, months & 5 & 2 \\
\hline
\end{tabular}

(a) The specimen size is 0.150 in OD by 1 in. long. 
alloys with some pins containing amounts of zirconium, molybdenum, or niobium. The enrichments of the se pins will be adjusted so that the amount of uranium-235 will remain constant for all pins of each type.

Table B-8 presents a summary of the irradiation parameters on which the capsule design is being based. This design will be essentially a double-wall configuration in which radial groups of three pins (five groups per capsule) will be immersed in NaK (or sodium) contained in a sealed inner shell. This as sembly will be housed in a watercontacting outer shell. The annular space between the inner and outer shells is being selected to provide a heat-transfer design compatible with the anticipated fission-heat productions and the desired specimen temperatures. According to preliminary analog studies, a satisfactory design for the niobium-uranium-specimen capsules can be based on a 10 to 15-mil inert-gas-filled annulus. In the case of the thorium-uranium-specime capsules, where the fission-heat generation will be higher and the fission heating lower, a gap of this general size will also be satisfactory; however, additional heat-transfer capacity will be required in the form of thin axial fins which bridge a small fraction of the annular space. Thus, as now anticipated, the only difference in the capsules from the heat-transfer viewpoint will be the axial fins in the thorium-uranium-specimen systems.

Because of metallurgical considerations, it is important that specimen temperatures in-pile be closely controlled and well monitored. Current plans to satisfy this requirement include (1) locating a sheathed thermocouple adjacent to each specimen in all capsules and (2) providing in each capsule both auxiliary electrical heaters and an annulus in which the thermal conductance can be changed in-pile by manual regulation of the helium-argon composition present. In the latter scheme, the gas-mixture regulation of the helium-argon composition present. In the latter scheme, the gas-mixture regulation is regarded as a secondary control which will avoid full dependency on the heaters.

At present, emphasis is being placed on completing details of the heat-transfer and temperature-control schemes. Design of various mechanical details will commence early in May and probably will be completed by early June. The present schedule calls for insertion of two capsules in the WTR in August. 


\section{FISSION-GAS RELEASE FROM \\ REFRACTORY FUELS(AEC-DRD)}

J. B. Melehan, M. Kangilaski, D. A. Vaughan, R. H. Barnes, H. D. Sheets, S. D. Beck, and F. A. Rough

Diffusion in $\mathrm{UO}_{2}$. . . . . . . . . . . . . . . . . . . C-2

Characterization of Sintered $\mathrm{UO}_{2}$ and Model of Gas Release . . . . C-2

In-Pile Study of Gas Release . . . . . . . . . . . . . . . C-3

The principal objective of this research is to understand the in-pile release of fission products from $\mathrm{UO}_{2}$. Thus, the major effort is presently being devoted to experimentation in the Battelle Reactor, where an induction-heated furnace is operating in an 8 -in. beam tube. The gases and other elements being released during continuous irradiation of a $\mathrm{UO}_{2}$ sample are being collected by suitable traps for analysis. Research is also in progress in several supporting areas, such as out-of-pile determination of diffusion of iodine and of xenon in $\mathrm{UO}_{2}$ and preparation and characterization of materials for study. 
During April, measurements of fission-gas release from uranium dioxide during postirradiation heat treatment were continued. Measurements of fission-gas release from two flat plates of single-crystal Norton uranium dioxide were made. One specimen was heat treated at $1394 \mathrm{C}$ while the other was heated initially at about $1200 \mathrm{C}$ for around $6 \mathrm{hr}$ and then at about $1400 \mathrm{C}$ for $6 \mathrm{hr}$. The xenon-release rate as a function of time followed the same characteristic pattern that was observed in the earlier runs which was described in the last monthly report (BMI-1430).

Analysis of the data from all the experiments that have been performed is currently in progress and should be completed soon. However, preliminary analyses indicate that the diffusion coefficients for Xenon-133 from those first runs are quite low, being about $1 \times 10^{-17} \mathrm{~cm}^{2}$ per sec at $1200 \mathrm{C}$ and about $1.1 \times 10^{-16} \mathrm{~cm}^{2}$ per sec at $1400 \mathrm{C}$.

Measurements of release rates of fission gases from additional plates of singlecrystal uranium dioxide in the range of 1200 to $1600 \mathrm{C}$ are scheduled to continue. Changes are being made in the heat-treatment apparatus to handle helium-hydrogen mixtures so that the effect of a reducing atmosphere on fission-gas release can be studied.

In addition, the diffusion coefficient of iodine in uranium dioxide is being determined. Iodine is a fission-product precursor of xenon, and, in order to determine the diffusion coefficient of xenon in $\mathrm{UO}_{2}$ from in-pile gas-release data, the diffusion coefficient of iodine in $\mathrm{UO}_{2}$ should also be determined. The experimental procedure consists of exposing uranium dioxide specimens to an iodine atmosphere at temperatures ranging from 1000 to $1200 \mathrm{C}$ and then analyzing the specimens for iodine. By use of diffusion equations and the results of the analyses, the diffusion coefficient of iodine in uranium dioxide is determined. With the se data, the contribution of iodine diffusion to xenon release can then be separated from the contribution of xenon diffusion.

During the past month, the $\mathrm{UO}_{2}$ specimens were prepared. The specimens are irregular slabs with thicknesses varying from 70 to 100 mils. Two $\mathrm{UO}_{2}$ specimens were exposed to an iodine atmosphere. The first one was exposed for $234 \mathrm{hr}$ at $1000 \mathrm{C}$. The second one was exposed for $121 \mathrm{hr}$ at $1200 \mathrm{C}$. Both of the se specimens are presently being analyzed. A very thin slab $(12 \mathrm{mils})$ was exposed to the iodine atmosphere at $1200 \mathrm{C}$ for $121 \mathrm{hr}$. It was estimated that during that time at $1200 \mathrm{C}$ the slab would become saturated with iodine. If present assumptions are correct, the concentration of iodine in this slab may be as high as $10.4 \mathrm{w} / 0$. This concentration is based on the assumption that iodine will fill all the largest interstitial holes in the $\mathrm{UO}_{2}$ lattice.

It is planned that two more specimens will be exposed to an iodine atmosphere, one at $1050 \mathrm{C}$ and the other at $1100 \mathrm{C}$. Results from the first two experiments will be available soon.

Characterization of Sintered $\mathrm{UO}_{2}$ and Model of Gas Release

Only limited research was done this month on the preparation of sintered $\mathrm{UO}_{2}$ and on studies of the pore structure directed toward understanding the geometric model of gas release. However, additional effort was devoted to evaluation of the techniques of pore-structure analysis. Results of this research will be available in the future. 


\section{In-Pile Study of Gas Release}

The in-pile experiment is now operating, and operational experience is being analyzed to provide a basis for conduct of experiments. It is expected that many aspects of fission-product diffusion can be analyzed, as indicated in the following:

(1) $\mathrm{D} / \mathrm{a}^{2}$ and $\mathrm{D}$ for xenon and krypton in sintered material, and the effects of irradiation upon these quantities

(2) Diffusion rates of iodine and bromine in-pile and their contribution to xenon and krypton release

(3) The activation energy for diffusion at high temperatures in-pile

(4) Qualitative data on the release of other fission products. 
GENERAL FUEL-ELEMENT DEVELOPMENT(AEC-DRD)

\author{
S. J. Paprocki
}

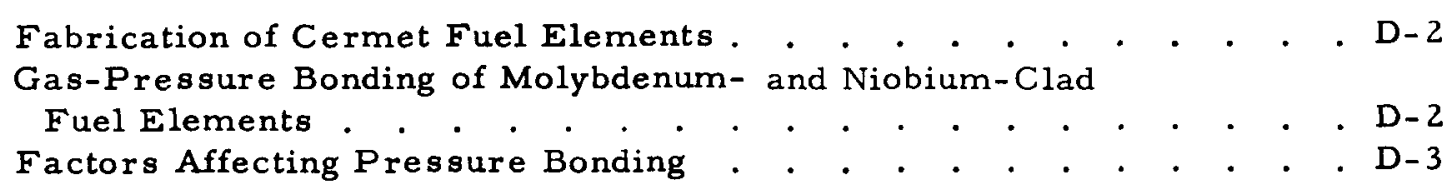

Techniques have been developed for the fabrication of cermet fuel materials consisting of 80 volume per cent of $\mathrm{UO}_{2}$ and 20 volume per cent of a metal phase. Current studies are concerned with the determination of modulus-of-rupture, thermalconductivity, electrical-resistivity, and mean-thermal-expansion properties of cermets prepared with stainless steel, molybdenum, chromium, and niobium matrices.

The gas-pressure-bonding process is being utilized for the solid-phase bonding of niobium fuel elements and assemblies. Multiplate assemblies have been prepared in one operation from plate and strip components. A technique has also been developed for producing a niobium-clad $\mathrm{UO}_{2}$ rod-type fuel element by forming the tube from a flat sheet of niobium.

The kinetics involved in a solid-phase bonding process that involves pressure and temperature such as the gas-pressure-bonding process are being investigated. The results from this study are finding direct application in the practical studies utilizing the gas-pressure-bonding process. 
S. J. Paprocki, D. L. Keller, G. W. Cunningham, and D. E. Kizer

Cermets fabricated by pressure-bonding techniques containing 80 volume per cent $\mathrm{UO}_{2}$ dispersed in stainless steel, molybdenum, chromium, and niobium are currently being tested to determine their physical and mechanical properties.

Modulus-of-rupture measurements have been made on 80 volume per cent $\mathrm{UO}_{2}-$ Type $302 \mathrm{~B}$ stainless steel and-molybdenum cermets. The modulus specimens were ground from cermet cores which were prepared by green pressing the respective powder mixes in a 1 by 1 -in. die prior to pressure bonding for $3 \mathrm{hr}$ at $10,000 \mathrm{psi}$ and 2250 to $2300 \mathrm{~F}$. The thickness and width of the test specimens were, respectively, 0.070 and 0.150 in. The span of loading was 0.83 in. Highest modulus-of-rupture values were 12,900 and $14,900 \mathrm{psi}$, respectively, for stainless steel cermets having densities of 93 and 96 per cent of theoretical and 15,600 and 12,000 psi, respectively, for molybdenum cermets of 87 and 92 per cent of theoretical density. Since the cermets are brittle, the corners of the modulus specimens were chipped after the grinding operation. Additional modulus-of-rupture specimens have been pressure bonded in a round configuration and are being ground to eliminate the chipping noted on the rectangular specimens.

Thermal-conductivity measurements have been made on an 80 volume per cent $\mathrm{UO}_{2}$-molybdenum cermet rod of $94.4 \mathrm{per}$ cent of theoretical density. Interpolated values read off a smooth curve through the data were $0.189,0.179,0.205$, and $0.250 \mathrm{w} /(\mathrm{cm})$ (C), respectively, at $200,500,700$, and $900 \mathrm{C}$.

In addition, mean-thermal-expansion and electrical-resistivity measurements are being made on 80 volume per cent $\mathrm{UO}_{2}$-molybdenum, -chromium, and -niobium cermets over the temperature range of 100 to $900 \mathrm{C}$.

\section{Gas-Pressure Bonding of Molybdenum- and Niobium-Clad Fuel Elements}

S. J. Paprocki, E. S. Hodge, and P. J. Gripshover

Investigations are being conducted to develop techniques for cladding fuel elements with niobium or molybdenum by the gas-pressure-bonding process. Evaluation of specimens is based on the quality of bond obtained and the properties of the cladding material after bonding. Current emphasis is being placed on the techniques for preparing niobium-clad fuel elements.

Examinations of specimens of niobium-clad compartmented fuel plates by burst test and metallography reveal that, even though some areas characterized by a lack of grain growth are observed in vertical bonds in fuel plates, failure is through the cladding during burst testing. Failure through the cladding rather than through the vertical bonds reveals that the occasional lack of grain growth observed metallographically does not as seriously impair the bond strength as originally thought. Several specimens bonded at $2100 \mathrm{~F}$ for $3 \mathrm{hr}$ at 10,000 psi have consistently shown good burst characteristics in spite of some metallographically observed lack of complete grain growth at the vertical bonds. 
An integral subassembly consisting of three compartmented fuel plates and two coolant channels $0.070 \mathrm{in}$. thick has been successfully pressure bonded at the previously described parameters. This specimen was fabricated in one step from 49 individual core and cladding components. The bonded assembly measured 0.5 by 1.5 by 5.5 in. Uranium dioxide spacers were used to form the coolant channels and were removed by pickling after pressure bonding. Excellent dimensional control was maintained among all components. Bond qualities obtained in this specimen were comparable to those described above for flat-plate specimens bonded under the se same conditions.

Successful efforts have been made to clad cylindrical uranium dioxide pellets with niobium sheet. The niobium sheet was wrapped around the uranium dioxide cores, overlapped, inserted in a stainless steel jacket, and pressure bonded at $2100 \mathrm{~F}$ and $10,000 \mathrm{psi}$ for $3 \mathrm{hr}$. Each side of the overlap was tapered so that an element of uniform diameter and cladding thickness resulted. Metallographic examination of a cross section of this specimen showed that satisfactory bonding had occurred, although a limited number of voids were present in some areas of the bond interface. This approach has desirable economic features, since it permits the formation of the tubing and the fabrication of the finished fuel element in one operation.

In an effort to determine the thermal stability of niobium-clad uranium dioxide fuel elements, a rod-type element has been thermal cycled between room temperature and $1800 \mathrm{~F}$. The specimen was encapsulated in Vycor with an argon atmosphere to minimize oxidation. Twenty-five cycles were complated, each cycle consisting of 30 min at $1800 \mathrm{~F}$ and $30 \mathrm{~min}$ to air cool to room temperature. No evidence of dimensional changes could be detected. Metallographic examination indicated no adverse effects on the niobium self-bonds and no apparent reaction between the core and cladding. A slight increase in grain size of the niobium was noted.

It is planned to prepare a number of niobium-clad fuel elements containing uranium dioxide, uranium carbide, and uranium dioxide-niobium cermets. Additional thermalcycling tests are also planned on the different clad fuel systems.

\section{Factors Affecting Pressure Bonding}

G. W. Cunningham and J. W. Spretnak

A study is being made of the mechanism of solid-state bonding of metals under application of heat and pressure. Most of the work is being conducted with OFHC copper specimens, and experiments currently being performed are intended to provide information of the effect of pressure, temperature, grain size, and surface roughness on the nature of the bond.

Previously reported results indicated that, in order to place the surface of two pieces of copper in intimate contact, a pressure of approximately 60 per cent of the value for the Vickers hot hardness as expressed in pounds per square inch is required. Data on specimens bonded at temperatures higher than $1000 \mathrm{~F}$ do not clearly show this behavior, and, in general, much lower pressures are sufficient. In earlier reports, it was suggested that lower pressures actually deform the metal sufficiently to bring the surfaces in contact, but upon release of pressure, elastic stresses are relieved and weak bonds are broken. The behavior of specimens at high temperatures, however, 
suggests that, in the range where rapid annealing occurs and where sintering and grain growth also proceed at a reasonable rate, strong bonds will be formed after a very short time, and, upon release of elastic stresses, the specimen will expand uniformly without breaking bonds in localized areas. Additional specimens will be prepared to establish the relationship between bond area and pressure, but it appears that, at the high temperatures, a pressure of approximately 0.2 to 0.3 times the Vickers hot hardness is sufficient to obtain intimate contact along the entire bond line.

The effect of surface roughness is being evaluated by bonding specimens at 400 and $1200 \mathrm{~F}$. Surfaces placed in contact include $8-\mu$ in., rms, specimens bonded to 125,205 , and 500- $\mu \mathrm{in}$., rms, shaped surfaces. Examination of as-bonded specimens indicates that as the surface-roughness value, and, therefore, the height of asperities, decreases the macroporosity also decreases. For example at $400 \mathrm{~F}$ and $4000 \mathrm{psi}$ of pressure, the 8 to $500-\mu$ in., rms, surfaces resulted in a bond line with 69.5 per cent visible void areas. The 8 to $250-\mu$ in. bond resulted in 25 per cent void area along the bond line, and the 8 to $125-\mu$ in. bond resulted in 12 per cent visible void area. However, after annealing $4 \mathrm{hr}$ at $1900 \mathrm{~F}, 42.8$ per cent void area was measured along the 8 to $500-$ $\mu$ in. bond, 9 per cent void area was measured on the 8 to $250-\mu$ in. bond line, and 15 per cent void area was measured on the 8 to $125-\mu$ in. bond line. Similar results were obtained on specimens bonded at $1200 \mathrm{~F}$. This behavior suggests that at least two factors are involved which operate in such a manner as to produce an optimum surface roughness. First of all, when the surface is smoother, less deformation and pressure are required to bring all areas of the bond line into intimate contact. On the other hand, since at any one time more area is in contact on the smoother surface, no area will receive as high a pressure as areas of early contact on the rough-machined specimens. Thus, even though less area is bonded on the rough-machined specimens, those areas should be more strongly bonded.

A study is also being made of the effect of grain size on the area of contact at any given pressure. The results indicate that, at least at low temperature $(400 \mathrm{~F})$, smallgrained specimens require a higher pressure than large-grained specimens to achieve the same area of contact at the bond line. At high temperatures, this relationship cannot be clearly shown, since growth of the small grains tends to eliminate porosity in the bond line. 
GAS-PRESSURE BONDING OF CERAMIC, CERMET, AND DISPERSION FUEL ELEMENTS (AEC-FUEL CYCLE)

S. J. Paprocki, S. W. Porembka, D. L. Keller, E. S. Hodge, C. B. Boyer, and J. B. Fox

Uranium Dioxide Compaction Studies . . . . . . . . . . . . E-2

Gas-Pressure Bonding. . . . . . . . . . . . . . . E-3

This program is concerned with the refinement and further development of the gaspressure-bonding technique for the fabrication of ceramic, cermet, and dispersion fuel elements. The process appears to be a likely method for maintaining or improving fue1element quality, while reducing manufacturing costs. This study is directed toward a twofold objective: simultaneously densifying the powder fuels and cladding the core with stainless steel. The major emphasis in the experimental work to date has been placed on the development of fuel elements consisting of $\mathrm{UO}_{2}$ ceramic bodies clad with Type 304 stainless steel. It is anticipated that the techniques developed for this combination of fuel-element materials will require little further development to be utilized for uranium dioxide dispersion and cermet fuel systems. 


\section{Uranium Dioxide Compaction Studies}

Uranium dioxide compaction studies have been directed toward attaining a high green density which will achieve a range of desired densities during pressure bonding. Various commercial powders and mixtures have been evaluated on the basis of coldcompacting characteristics. Investigations were also made on the effect of particle-size range and the effects of mixtures of $\mathrm{UO}_{2}$ on attainable pressure-bonded density. At present, a more detailed study of the se parameters coupled with the production of slurrytype additions of binders is being undertaken.

A study to determine the compacting and pressure-bonding characteristics of offstoichiometry fused uranium dioxide has been initiated. The oxide for preliminary tests was flash roasted for $5 \mathrm{~min}$ at $550 \mathrm{~F}$ to attain a previously determined oxygen-to-uranium ratio of 2.04. Cold compacting with a binder addition resulted in a green density of $9.50 \mathrm{~g}$ per $\mathrm{cm}^{3}$, which indicates no significant effect of the excess oxygen on the compacted density. Pressure bonding the same material for $3 \mathrm{hr}$ at $2100 \mathrm{~F}$ and $10,000 \mathrm{psi}$ yielded densities of $10.1 \mathrm{~g}$ per $\mathrm{cm}^{3}$ (92.1 per cent of theoretical). This density represents a significant increase over the maximum density of 89 per cent of theoretical attainable with the stoichiometric fused oxide as pressure bonded under the same conditions. Further tests will be conducted with materials of varying oxygen-to-uranium ratios.

The determination of cold-compacting characteristics of mixtures of ceramic and fused uranium dioxide powders has been completed. Densities for typical compacts in this investigation are presented in Table $E-1$ where the results are categorized as to acceptability on the basis of 70 per cent of theoretical density. In general, higher compacted densities were attained with the as-received (minus 20 mesh) and the minus 325mesh particle distributions in mixtures which contained the fused oxide as the major constituent. Representative compacts of the various mixtures and particle sizes have been pressure bonded for $3 \mathrm{hr}$ at $2100 \mathrm{~F}$ and $10,000 \mathrm{psi}$, and the resulting materials are presently being evaluated.

TABLE E-1. COLD-COMPACTING CHARACTERISTICS OF VARIOUS MIXTURES OF CERAMIC AND FUSED UO 2 POWDERS COMPACTED AT 50 TSI WITH CEREMUL "C" BINDER

\begin{tabular}{lll}
\hline Specimen & Mixture & Density, g per cm \\
\hline & Acceptable $(>70$ Per Cent Theoretical Density) & \\
U1469 & 70 w/o fused $(-20) 30$ w/o ceramic $(-325)$ & 8.66 \\
U1472 & 60 w/o fused $(-20) 40$ w/o ceramic $(-325)$ & 8.14 \\
U1476 & 50 w/o fused $(-20) 50$ w/o ceramic $(-325)$ & 7.84 \\
U1458 & 75 w/o fused $(-325) 25$ w/o ceramic $(-325)$ & 8.14 \\
U1461 & 65 w/o fused $(-325) 35$ w/o ceramic $(-325)$ & 8.16 \\
& & \\
U1480 & Acceptable $(<70$ Per Cent Theoretical Density) & \\
U1484 & 40 w/o fused $(-20) 60$ w/o ceramic $(-325)$ & 7.64 \\
U1506 & 25 w/o fused $(-20) 75$ w/o ceramic $(-325)$ & 7.32 \\
U1505 & 75 w/o fused $(-100) 25$ w/o ceramic $(-325)$ & $7.88(a)$ \\
U1502 & 50 w/o fused $(-100) 50$ w/o ceramic $(-325)$ & 7.31 \\
U1488 & 25 w/o fused $(-100) 75$ w/o ceramic $(-325)$ & 6.94 \\
U1493 & 75 w/o fused $(-200) 25$ w/o ceramic $(-325)$ & 7.43 \\
U1497 & 50 w/o fused $(-200) 50$ w/o ceramic $(-325)$ & 7.11 \\
U1466 & 25 w/o fused $(-200) 75$ w/o ceramic $(-325)$ & 6.94 \\
\hline
\end{tabular}

(a) Majority of compacts in this size range fractured. 
Current efforts in the study of the effect of binder additions on the compacting characteristics of uranium dioxide concern the processing of slurry-type mixes. The water from such mixes is evaporated by heat during the mixing operation thus yielding completely waxed particles. Powders prepared in this manner yield high-strength green compacts with well-defined edges. In order to retain the good surface qualities of such compacts, extremely slow heating cycles are planned for dewaxing.

Initial results of tests on coating uranium dioxide compacts with nickel during the compacting operation show considerable promise. This coating is accomplished by using a mixture of fine nickel particles dispersed in ethylene glycol as a die lubricant. Finished compacts as prepared by this method are coated with from 0.001 to 0.003 in. of nickel and exhibit high green strength. Pressure-bonding studies of nickel-coated compacts are presently in progress.

\section{Gas-Pressure Bonding}

Type 304 stainless steel-clad $\mathrm{UO}_{2}$ rod, tube, and flat-plate elements and flatplate assemblies have been fabricated by the gas-pressure-bonding method. Excellent dimensional tolerances have been achieved when high-density cores are used; however, problems of dimensional tolerances, shrinkage, warpage, and deformation of the cladding are encountered when low-density green-pressed cores or tapped powders are used as the initial core material. Investigations are being conducted to evaluate various fuelelement shapes, such as the corrugated rod or tube design, which show promise for utilizing low-density cores. The development of high-density green-pressed $\mathrm{UO}_{2}$ cores has greatly minimized densification effects, and such cores are being utilized in further fuel-element investigations.

The three tubes containing cold-pressed Type 304L stainless steel powder cores with densities of 78,82 , and 88 per cent of theoretical were pressure bonded at $2100 \mathrm{~F}$ for $3 \mathrm{hr}$ at $10,000 \mathrm{psi}$. The densities of these cores after pressure bonding were 97.4, 97.6, and 97.6 per cent of theoretical, respectively. These results indicate that the use of cold-pressed stainless steel cores as end plugs and compartment spacers in tube-type elements is feasible.

To further evaluate stainless steel powder spacers for compartmentalized fuel rods an attempt to match the final movement and deformation of the se spacers to that of a green-pressed $\mathrm{UO}_{2}$ core was made. Three exploratory 0.540 -in. - ID tubes with a 20-mil wall thickness were loaded with $\mathrm{UO}_{2}$ cores using the stainless steel powdered cores with a theoretical density of 82 per cent. The green-pressed $\mathrm{UO}_{2}$ cores, which contained mixtures of the fused and ceramic oxides, represented densities of 73, 74, and 68 per cent of theoretical. Four of the se $\mathrm{UO}_{2}$ cores were contained in each of the three tubes. All cores in a single tube were of the same density. These tubes were pressure bonded at $2100 \mathrm{~F}$ for $3 \mathrm{hr}$ at $10,000 \mathrm{psi}$. Preliminary examination of the specimens revealed that the diameter measurements of the tube containing the cores having a density of 68 per cent of theoretical varied only 2 to 3 mils over a 4 -in. total specimen length. The specimens are being further examined for density and microstructure.

Further work will be aimed at a more complete evaluation of the fuel-element designs and the properties of the pressure-bonded $\mathrm{UO}_{2}$. 


\title{
DEVELOPMENT OF URANIUM CARBIDE \\ (AEC-FUEL CYCLE)
}

F. A. Rough and W. Chubb

\begin{abstract}
Alternate Fabrication Methods for UC . . . . . . . . . . . F-2
Melting and Casting Techniques for Uranium-Carbon Alloys . . . F-4

Mechanical and Physical Properties of Uranium Monocarbide . . . F-5

Uranium Monocarbide Diffusion Studies . . . . . . . . . F-9

Irradiation Effects in UC . . . . . . . . . . . . . . F-10
\end{abstract}

As a portion of the Fuel-Cycle Development Program, sponsored by the AEC, an integrated program of research on the preparation and properties of uranium carbides is in progress at Battelle. This program includes investigations of the preparation and forming of uranium carbides by powder metallurgical and by melting and casting techniques. The mechanical, physical, and chemical corrosion and metallurgical compatibility characteristics of uranium carbides and their alloys are being determined. A fundamental study of diffusion rates in uranium carbides has been undertaken, and studies are in progress in an effort to obtain fundamental data on the nature of irradiation-damage processes in uranium carbides.

Work in previous months has shown that powder compacts prepared by a hot hydrostatic-pressing technique at a temperature of only $1320 \mathrm{C}$ results in a uranium carbide product having a density in excess of 95 pex cent of theoretical. Studies during the last month continue to show that cold pressing and sintering at temperatures near $1900 \mathrm{C}$ consistently produce structures of less than 90 per cent of theoretical density, except under conditions involving liquid-phase sintering.

Information has been reported in previous months with respect to the variation of the strength, density, and resistivity of uranium carbides as a function of composition. The compatibility of carbides with various metals at certain temperatures has been reported, and these studies are being extended. Information obtained this month indicates that extensive reaction occurs at $800 \mathrm{C}$ in $100 \mathrm{hr}$ between stainless steel and UC and between zirconium and UC. Inconel shows a decrease in hardness in a zone approximately $0.003 \mathrm{in}$. thick after being in contact with UC for $100 \mathrm{hr}$ at $800 \mathrm{C}$. Mild steel shows no serious effects after being in contact with UC for $100 \mathrm{hr}$ at either 800 or $900 \mathrm{C}$.

Additional information has been obtained with respect to the effect of alloy additions upon the corrosion resistance of uranium carbides. Additions of molybdenum, niobium, titanium, and vanadium as metals and as carbides have shown a beneficial effect in UC. Data reported this month show that these same additions and zirconium and zirconium carbide have beneficial effects upon the corrosion resistance of $\mathrm{U}_{2} \mathrm{C}_{3}$ and $\mathrm{UC}_{2}$. A method of making sound castings of $\mathrm{UC}$ alloyed with zirconium or zirconium carbide has not been found to date. 


\section{Alternate Fabrication Methods for UC}

\section{S. J. Paprocki, D. L. Keller, D. E. Kizer, J. M. Fackelmann,} and E. O. Speidel

Powder-metallurgy techniques for producing useful uranium carbide components are being investigated.

Vacuum sintering various powder compacts for $2 \mathrm{hr}$ at an optically measured temperature of $1900 \mathrm{C}$ produced bodies with bulk densities, as indicated in Table F-1, which ranged from an average value of $11.3 \mathrm{~g}$ per $\mathrm{cm}^{3}$ for $15-\mu$-diameter powder obtained by ball milling arc-melted UC buttons having a carbon content of $4.94 \mathrm{w} / \mathrm{o}$ to $13.0 \mathrm{~g}$ per $\mathrm{cm}^{3}$ for Numec buttons containing $4.89 \mathrm{w} / \mathrm{o}$ carbon that were ball milled to an average particle size of $6 \mu$. Microscopic examination of the latter compacts showed two phases to be present, UC and uranium. The combined oxygen and nitrogen content of the Numec compacts was $0.80 \mathrm{w} / 0$ as shown in Table F-1. Most of the oxygen was picked up during ball milling.

Uranium $-4.85 \mathrm{w} / \mathrm{o}$ carbon powder prepared by passing methane over uranium in a dynamic system contained large amounts of impurities. The measured bulk density of compacts prepared with this powder was $12.5 \mathrm{~g}$ per $\mathrm{cm}^{3}$ after sintering. The $1.1 \mathrm{w} / \mathrm{o}$ free carbon observed in this powder reacted during sintering, since no free graphite was observed microscopically. The structure of these compacts was heterogeneous with respect to grain size and chemical content as evidenced by unidentified phases in the microstructure. It would appear that the UC powder prepared by this dynamic method is considerably inferior to the powder produced previously in a static system with respect to the characteristics of the sintered product and the impurity content of the starting powder.

Sintering relatively coarse UC powder in static argon at $1900 \mathrm{C}$ resulted in a loss of carbon, a product having 70 per cent of theoretical density, and a structure containing no free uranium. Pertinent data are summarized in Table F-1. An unidentified platelet type of precipitate, possibly $\mathrm{UC}_{2}$, was observed within the UC grains.

Varying amounts of chromium have been added to UC powders to enhance sintering by the presence of liquid-phase chromium. Spectrographic analyses of UC-8 w/o chromium compacts after sintering $45 \mathrm{~min}$ at a temperature of $1820 \mathrm{C}$ or greater showed that the chromium was completely removed, less than $0.01 \mathrm{w} / \mathrm{o}$ being detected. Chemical, vacuum-fusion, and metallographic analyses of compacts sintered at $1820 \mathrm{C}$ showed $0.224 \mathrm{w} / \mathrm{o}$ oxygen, $4.55 \mathrm{w} / \mathrm{o}$ carbon, $0.23 \mathrm{w} / \mathrm{o}$ nitrogen, and $95.0 \mathrm{w} / \mathrm{o}$ uranium present in a structure consisting essentially of one phase similar to UC. Densification was evident at $1780 \mathrm{C}$ with many areas 100 per cent dense; however, enough chromium had distilled off to leave some large voids. The benefits of liquid-phase chromium are exhibited below $1890 \mathrm{C}$, the melting point of chromium, because it is present as the chromium-uranium eutectic. Smaller quantities of chromium are being mixed with UC in an attempt to produce compacts of high densities at lower fabricating temperatures.

In several instances, noted above, large amounts of oxygen and nitrogen were detected by vacuum-fusion and chemical analyses when there was no microscopic 
TABLE F-1. DATA ON URANIUM CARBIDE COMPACTS SINTERED 2 HR IN VACUUM AT $1900 \mathrm{C}$ EXCEPT AS NOTED

\begin{tabular}{|c|c|c|c|c|c|c|c|c|c|c|c|}
\hline \multirow[b]{3}{*}{ Method of Preparing Powder } & \multirow{3}{*}{ 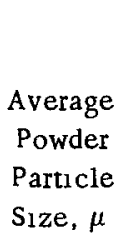 } & \multirow{2}{*}{\multicolumn{2}{|c|}{$\begin{array}{c}\text { Carbon Content, } \\
\text { w/o }\end{array}$}} & \multirow{2}{*}{\multicolumn{2}{|c|}{$\begin{array}{c}\text { Oxygen Content, } \\
\text { w/o }\end{array}$}} & \multirow{2}{*}{\multicolumn{2}{|c|}{$\begin{array}{c}\text { Nitrogen Content, } \\
\text { w/o }\end{array}$}} & \multicolumn{4}{|c|}{ Properties of Sintered Compact } \\
\hline & & & & & & & & \multirow{2}{*}{$\begin{array}{l}\text { A verage } \\
\text { Bulk } \\
\text { Density, } \\
\text { g per } \mathrm{cm}^{3}\end{array}$} & \multirow{2}{*}{$\begin{array}{c}\text { Average } \\
\text { Metallographic } \\
\text { Density, } \\
\text { per cent of } \\
\text { theoretical }\end{array}$} & \multicolumn{2}{|c|}{ Grain Size, } \\
\hline & & Powder & Sintered & Powder & Sintered & Powder & Sintered & & & Average & Maximum \\
\hline $\begin{array}{l}\text { Ball milling arc-melted buttons in } \\
\text { argon }\end{array}$ & 15 & 4.94 & -- & 0.2720 & -- & 0.015 & -- & 11.3 & - & - & -- \\
\hline Ball milling Numec buttons in kerosene & 6 & $4.89^{(a)}$ & 3.87 & $0.1900^{(a)}$ & 0.4790 & $0.3100^{(a)}$ & 0.32 & 13.0 & 95 & 50 & 250 \\
\hline Flowing methane reacted with uranium & 6 & 4.85 & -- & 1.39 & -- & 0.54 & -- & 12.5 & 85 & 8 & 375 \\
\hline Crushing arc-melted buttons in argon & 25 & 4.83 & $4.55(b)$ & 0.1200 & -- & 0.011 & -- & 9.5 & 70 & 35 & (c) \\
\hline
\end{tabular}

(a) Analysis of buttons obtained before ball milling to powder

(b) Sintered $4 \mathrm{hr}$ in static argon atmosphere

(c) Unuform grain sıze 
evidence of their presence. Uranium nitride is known to be soluble in UC, and, tharefore, one would expect that relatively large amounts of nitrogen would dissolve in UC. No UO phase has been isolated and identified as such, but it would appear equally feasible for oxygen to form a substitutional solid solution in UC at low concentrations. The result noted above may represent a UC lattice with nitrogen and oxygen randomly substituted for carbon.

In addition to possibly accounting for the absence of free uranium in low-carbon materials in the presence of oxygen and nitrogen, the above hypothesis may also explain the precipitation of $\mathrm{UC}_{2}$ in alloys having carbon contents of less than $4.8 \mathrm{w} / \mathrm{o}$.

\section{Melting and Casting Techniques for Uranium-Carbon Alloys}

B. C. Boesser, W. M. Phillips, E. L. Foster, and R. F. Dickerson

Reliable techniques for the production of high-quality cast shapes of uranium carbide are being developed. Research directed toward improvement of casting techniques for large shapes of uranium carbide is in progress. Sound uranium carbide castings can now be produced with the composition controlled to within $\pm 0.3 \mathrm{w} / 0$ carbon from ingot to ingot. Individual ingots show variations of less than $\pm 0.1 \mathrm{w} / 0$ carbon within a casting.

During the past month, a new, small $(40 \mathrm{~kg})$ skull was built up in the skullcasting furnace, and several 1 -in. -hexagonal by 8 -in. -long castings were made. These hexagonal cylinders were cast into a thin-walled unheated graphite mold. All had good surfaces, and all were sound except for usually large shrinkage pipes. Past experience has shown that use of massive unheated molds results in poor castings; however, because of the thin wall section of this graphite mold, cooling of these ingots was slow enough to produce sound castings.

Initial results indicate that the smaller crucible skull gives better composition control ( $\pm 0.2 \mathrm{w} / \mathrm{o}$ carbon). Analyses, typical of the hexagonal castings are as follows: $5.17 \mathrm{w} / 0$ carbon, $54 \mathrm{ppm}$ oxygen, $50 \mathrm{ppm}$ nitrogen, $40 \mathrm{ppm}$ silicon, $20 \mathrm{ppm}$ aluminum, $20 \mathrm{ppm}$ calcium, $14 \mathrm{ppm}$ iron, $5 \mathrm{ppm}$ boron, $5 \mathrm{ppm}$ copper, $5 \mathrm{ppm}$ molybdenum, $2 \mathrm{ppm}$ magnesium, and $2 \mathrm{ppm}$ nickel. These castings have very low impurity contents, considering the fact that reactor-grade uranium and electrode-grade graphite were used. This low impurity content, particularly with respect to nitrogen and oxygen, is attributed to the dynamic vacuum imposed during arc melting.

Erosion of the graphite electrode tip was measured, and it was established that essentially all of the eroded carbon was picked up by the melt. Electrode erosion has been found to be dependent upon the time of melting, the current density, the atmosphere, the outgassing that occurs, the purity of the starting materials, and perhaps other factors.

Research during the next month will be concerned with further evaluation of the new skull and of electrode-tip erosion in an attempt to further improve composition control of uranium carbide castings. Studies of techniques to increase the quantity of 
material that can be produced in the skull-type arc furnace in a given time will be initiated.

Mechanical and Physical Properties of Uranium Monocarbide

W. M. Phillips, E. L. Foster, and R. F. Dickerson

Uranium carbides are being studied for the purpose of determining their properties, including density, resistivity, thermal conductivity, compressive strength, and corrosion resistance. To both define and improve the characteristics of the se materials, such variables as impurity content, carbon content, alloy content, and heat treatment are being investigated. The effects of these variables are being evaluated in terms of the above-mentioned properties.

Preliminary studies indicated that additions of molybdenum, niobium, titanium, and vanadium, or carbides of these metals, result in improvements in the corrosion resistance and in the transverse strength of uranium monocarbide. On the basis of these studies, these additions as well as chromium, tantalum, and zirconium and their carbides were added to the sesquicarbide and dicarbide of uranium. Tests on the latter alloys indicate that the transverse rupture strength is increased by certain of the carbide additions. The electrical resistivity of the sesquicarbide is increased by most of the alloy additions, while that of the dicarbide is reduced by most of the alloy additions. The density of the uranium carbon alloys is reduced approximately 2 per cent by $5 \mathrm{w} / \mathrm{o}$ alloy carbide and 5 per cent by an addition of $10 \mathrm{w} / \mathrm{o}$ alloy carbide. The results of these tests and corrosion tests are presented in Table F-2.

The alloys listed in Table F-2 are as-cast, mixtures of $U C$ and $U_{2}$. The amount of $\mathrm{U}_{2} \mathrm{C}_{3}$ produced in each case by the anneal has not yet been determined. Corrosion testing of the uranium-7 w/o carbon alloys indicates that $\mathrm{Mo}_{2} \mathrm{C}$ and $\mathrm{NbC}$ have effected significant reductions in the corrosion rate in Santowax R. This effect is identical to the effect of $\mathrm{Mo}_{2} \mathrm{C}$ and $\mathrm{NbC}$ upon the uranium monocarbide. However, in the case of the $7 \mathrm{w} / \mathrm{o}$ carbon alloy, an addition of $5 \mathrm{w} / \mathrm{o}$ alloy carbide was more effective than the $10 \mathrm{w} / \mathrm{o}$ addition; this is opposite to the effect observed for alloy additions to the monocarbide. The corrosion resistance of both the monocarbide and sesquicarbide alloys in Santowax $\mathrm{R}$ is decreased by annealing. The corrosion resistance in water vapor, however, is increased by annealing in both cases. During all corrosion testing, it was observed that a major portion of the attack took place at defects in the material. Centerline piping and surface defects were enlarged rapidly. None of the dicarbide alloys was as corrosion resistant as either the monocarbide or the sesquicarbide alloys.

Compatibility studies of uranium monocarbide with Inconel, mild steel, stainless steel (Type 304), and zirconium at 800 and $900 \mathrm{C}$ for $100 \mathrm{hr}$ have been completed. The results of these are given in Table F-3. Mild steel was apparently unaffected at 800 and $900 \mathrm{C}$. No reaction zone was observed during metallog raphic examination, the only indication of interaction being a very slight hardness increase in the area of contact of the $\mathrm{UC}$ and the mild steel. The tests were run using UC specimens of both slightly hypostoichiometric and hyperstoichiometric composition. No metallographic evidence of change of the hyperstoichiometric UC material was observed. However, the hypostoichiometric UC materials showed a depletion of the free uranium to depth of approximately $1 \mathrm{mil}$ in the UC. 
TABLE F-2. PROPERTIES OF URANIUM-CARBON ALLOYS

\begin{tabular}{|c|c|c|c|c|c|c|c|c|c|c|c|c|c|}
\hline \multirow{4}{*}{\multicolumn{2}{|c|}{$\begin{array}{c}\text { Alloy } \\
\text { Composition, } \\
\text { w/o } \\
\end{array}$}} & \multicolumn{6}{|c|}{ As-Cast Specımens } & \multirow{2}{*}{\multicolumn{6}{|c|}{ Specimens Annealed $1 \mathrm{Hr}$ at $1800 \mathrm{C}$}} \\
\hline & & \multirow{3}{*}{\multicolumn{2}{|c|}{ Rupture Stress, psi }} & \multirow{4}{*}{$\begin{array}{c}\text { Electrical } \\
\text { Resistıvity, } \\
\text { microhm-cm }\end{array}$} & \multicolumn{3}{|c|}{ Corrosion Rate ${ }^{(a)}, \mathrm{mg} /\left(\mathrm{cm}^{2}\right)$ (day) } & & & & & & \\
\hline & & & & & \multirow{3}{*}{$\begin{array}{c}\text { Santowax } \\
\mathrm{R} \text { at } \\
350 \mathrm{C}\end{array}$} & \multirow{3}{*}{$\begin{array}{c}\text { Water Vapor } \\
\text { at } 45 \mathrm{C}\end{array}$} & \multirow{3}{*}{$\begin{array}{l}\text { Dry Alr } \\
\text { at } 300 \mathrm{C}\end{array}$} & \multirow{2}{*}{\multicolumn{2}{|c|}{ Rupture Stress, psı }} & \multirow{3}{*}{$\begin{array}{l}\text { Electrical } \\
\text { Resistivity, } \\
\text { microhm-cm }\end{array}$} & \multicolumn{3}{|c|}{ Corrosion Rate $(\mathrm{a}), \mathrm{mg} /\left(\mathrm{cm}^{2}\right)$ (day) } \\
\hline & & & & & & & & & & & \multirow{2}{*}{$\begin{array}{l}\text { Santowax } \\
\mathrm{R} \text { at } 350 \mathrm{C}\end{array}$} & \multirow{2}{*}{$\begin{array}{c}\text { Water Vapor } \\
\text { at } 45 \mathrm{C}\end{array}$} & \multirow{2}{*}{$\begin{array}{l}\text { Dry A1r } \\
\text { at } 300 \mathrm{C}\end{array}$} \\
\hline Base & Addition & Transverse & Compressive & & & & & Transverse & Compressive & & & & \\
\hline $\mathrm{UC}_{2}$ & -- & 12,000 & -- & 102 & -- & -- & -- & 6,500 & -- & 125 & -- & -- & -- \\
\hline $\mathrm{U}_{2} \mathrm{C}_{3}$ & -- & 17,000 & - & 55 & -- & - & - & 15,000 & - & 45 & -- & -- & -- \\
\hline \multirow[t]{14}{*}{$\mathrm{U}_{2} \mathrm{C}_{3}$} & $5 \mathrm{Cr}_{3} \mathrm{C}_{2}$ & 28,000 & 62,000 & 100 & 0.92 & $\mathrm{D}$ & $\cdots$ & 9,000 & -- & $-\cdot$ & 2.67 & $\mathrm{D}$ & D \\
\hline & $10 \mathrm{Cr}_{3} \mathrm{C}_{2}$ & 13,000 & 98,000 & 150 & 3.36 & -- & $\cdots$ & 11,000 & -- & 125 & 3.19 & D & -- \\
\hline & $5 \mathrm{Mo}_{2} \mathrm{C}$ & 37,000 & 108,000 & 80 & +0.011 & -- & $\cdots$ & 25,000 & -- & 85 & +0.013 & 0.68 & -- \\
\hline & $10 \mathrm{Mo}_{2} \mathrm{C}$ & 19,000 & 93,000 & 92 & 3.06 & -- & -- & 16,000 & -- & 95 & 5.11 & -- & -- \\
\hline & $5 \mathrm{NbC}$ & 14,000 & 112,000 & -- & +0.013 & 1.38 & 59.5 & 22,000 & -- & 80 & +0.013 & 0.075 & - \\
\hline & $10 \mathrm{NbC}$ & 15,000 & 138,000 & 113 & 3.04 & -- & -- & 21,000 & -- & 96 & 3. 44 & 14.4 & -- \\
\hline & $5 \mathrm{TaC}$ & 24,000 & 94,000 & 76 & 0.009 & -- & -- & 14,000 & -- & 78 & 4.68 & D & -- \\
\hline & $5 \mathrm{~T}_{1} \mathrm{C}$ & 22,000 & 43,000 & 60 & 0.003 & -- & -- & 15,000 & -- & 54 & 1.38 & 4.17 & -- \\
\hline & $10 \mathrm{~T} 1 \mathrm{C}$ & 43,000 & 122,000 & -- & 5.48 & 0.19 & 0.0 & 23,000 & -- & 55 & 2.31 & 1.74 & -- \\
\hline & $5 \mathrm{VC}$ & 8,000 & 42,000 & 84 & 1.11 & -- & -- & 17,000 & -- & $\cdots$ & 5.95 & 33.0 & 2.77 \\
\hline & $10 \mathrm{VC}$ & -- & -- & -- & 0.39 & - & $\cdots$ & -- & -- & - & 8.22 & 0.11 & -- \\
\hline & 5 WC & 17,000 & 68,000 & 66 & 0.513 & - & -- & 16,000 & -- & 67 & 0.535 & 1.0 & - \\
\hline & 10 WC & 34,000 & 99,000 & 70 & 0.500 & -- & -- & 31,000 & -- & 66 & 0.535 & 3.29 & -- \\
\hline & $5 \mathrm{ZrC}$ & 27,000 & 109,000 & -- & 1.53 & -- & -- & 19,000 & -- & -- & 74 & 0.49 & -- \\
\hline \multirow[t]{16}{*}{$\mathrm{UC}_{2}$} & $5 \mathrm{Cr}_{3} \mathrm{C}_{2}$ & -- & 69,000 & -- & 1.55 & -- & $\cdots$ & 24,000 & -- & 82 & 2.84 & D & -- \\
\hline & $10 \mathrm{Cr}_{3} \mathrm{C}_{2}$ & 1,600 & 29,000 & 115 & 2.30 & -- & -- & 7,000 & -- & 125 & $\mathrm{D}$ & D & -- \\
\hline & $5 \mathrm{Mo}_{2} \mathrm{C}^{2}$ & 33,000 & 68,000 & 73 & 0.65 & -- & -- & 25,000 & -- & 72 & 0.65 & 0.103 & -- \\
\hline & $10 \mathrm{Mo}_{2} \mathrm{C}$ & - & -- & -- & -- & -- & -- & 23,000 & -- & 115 & 2.68 & 11.1 & -- \\
\hline & $5 \mathrm{NbC}$ & 34,000 & 79,000 & 76 & -- & -- & - & 30,000 & -- & 74 & 0.35 & 0.074 & -- \\
\hline & $10 \mathrm{NbC}$ & 23,000 & 94,000 & 82 & -- & -- & -- & 16,000 & - & 110 & 0.673 & 1.72 & -- \\
\hline & $5 \mathrm{TaC}$ & 42,000 & 140,000 & 88 & 0.82 & -- & -- & -- & - & -- & 0.88 & -- & -- \\
\hline & $10 \mathrm{TaC}$ & 23,000 & 112,000 & -- & 2.33 & -- & -- & 36,000 & -- & -- & 9.16 & -- & -- \\
\hline & $5 \mathrm{TiC}$ & -- & 36,000 & 67 & 1.15 & -- & -- & 21,000 & $\cdots$ & 63 & 0.49 & D & -- \\
\hline & $10 \mathrm{TiC}$ & -- & -- & -- & +0.013 & -- & -- & 21,000 & -- & 77 & 0.71 & 0.17 & +0.82 \\
\hline & $5 \mathrm{VC}$ & 32,000 & 134,000 & 74 & 2.50 & -- & -- & 29,000 & -- & 71 & 2.88 & 18.2 & -- \\
\hline & $10 \mathrm{VC}$ & 11,000 & 46,000 & 62 & 0.553 & -- & -- & 16,000 & - & 70 & 0.785 & 43.5 & -- \\
\hline & 5 WC & 33,000 & 87,000 & 78 & 0.548 & -- & -- & 29,000 & - & 82 & 0.706 & -- & -- \\
\hline & $10 \mathrm{WC}$ & 28,000 & 125,000 & 71 & 0.361 & - & -- & 31,000 & -- & 68 & 0.514 & 0.95 & -- \\
\hline & $5 \mathrm{ZrC}$ & 16,000 & 68,000 & 91 & +0.012 & -- & -- & 18,000 & -- & 80 & 1.41 & -- & -- \\
\hline & $10 \mathrm{ZrC}$ & 26,000 & 92,000 & 101 & 0.523 & -- & - & 20,000 & -- & 90 & 0.745 & 52.6 & -- \\
\hline
\end{tabular}


TABLE F-2. (Contınued)

\begin{tabular}{|c|c|c|c|c|c|c|c|c|c|c|c|c|c|}
\hline \multicolumn{8}{|c|}{ As-Cast Specimens } & \multirow{2}{*}{\multicolumn{6}{|c|}{ Specimens Annealed $1 \mathrm{Hr}$ at $1800 \mathrm{C}$}} \\
\hline \multirow{3}{*}{\multicolumn{2}{|c|}{$\begin{array}{c}\text { Alloy } \\
\text { Composition, } \\
\text { w/o } \\
\end{array}$}} & \multirow{3}{*}{\multicolumn{2}{|c|}{ Rupture Stress, psı }} & \multirow{4}{*}{$\begin{array}{c}\text { Electrical } \\
\text { Resıstıvity, } \\
\text { microhm-cm }\end{array}$} & \multicolumn{3}{|c|}{ Corrosion Rate $(\mathrm{a}), \mathrm{mg} /\left(\mathrm{cm}^{2}\right)$ (day) } & & & & & & \\
\hline & & & & & \multirow{3}{*}{$\begin{array}{c}\text { Santowax } \\
\text { R at } \\
350 \mathrm{C} \\
\end{array}$} & \multirow{3}{*}{$\begin{array}{c}\text { Water Vapor } \\
\text { at } 45 \mathrm{C}\end{array}$} & \multirow{3}{*}{$\begin{array}{l}\text { Dry Alr } \\
\text { at } 300 \mathrm{C}\end{array}$} & \multirow{2}{*}{\multicolumn{2}{|c|}{ Rupture Stress, psi }} & \multirow{3}{*}{$\begin{array}{r}\text { Electrical } \\
\text { Resistivity, } \\
\text { microhm -cm }\end{array}$} & \multicolumn{3}{|c|}{ Corrosion Rate(a), $\mathrm{mg} /\left(\mathrm{cm}^{2}\right)($ day $)$} \\
\hline & & & & & & & & & & & \multirow{2}{*}{$\begin{array}{l}\text { Santowax } \\
R \text { at } 350 \mathrm{C}\end{array}$} & \multirow{2}{*}{$\begin{array}{c}\text { Water Vapor } \\
\text { at } 45 \mathrm{C}\end{array}$} & \multirow{2}{*}{$\begin{array}{l}\text { Dry Arr } \\
\text { at } 300 \mathrm{C}\end{array}$} \\
\hline Base & $\overline{\text { Addition }}$ & Transverse & Compressive & & & & & Transverse & Compressive & & & & \\
\hline \multirow[t]{7}{*}{$\mathrm{U}_{2} \mathrm{C}_{3}$} & $5 \mathrm{Fe}$ & 23,000 & -- & 140 & 0.289 & $\mathrm{D}$ & -- & 40,000 & -- & -- & 0.460 & -- & -- \\
\hline & $5 \mathrm{Mo}$ & 26,000 & 48,000 & 82 & 0.361 & -- & -- & 20,000 & -. & 86 & 0.294 & 34.7 & -- \\
\hline & $5 \mathrm{Nb}$ & 6,000 & 90,000 & 95 & 0.278 & -- & -- & 29,000 & -- & 82 & 0.285 & 6.10 & -- \\
\hline & $5 \mathrm{~N} 1$ & -- & -- & - & -- & -- & -- & $=$ & -- & -- & 0.061 & D & -- \\
\hline & $5 \mathrm{~V}$ & -- & 67,000 & -- & 0.267 & $\mathrm{D}$ & -- & 21,000 & - & 57 & 0.592 & $\mathrm{D}$ & -- \\
\hline & $5 \mathrm{~W}$ & 23,000 & 93,000 & 70 & 0.475 & -- & -- & 23,000 & -. & 170 & 0.139 & 1.11 & -- \\
\hline & $5 \mathrm{Zr}$ & 25,000 & 62,000 & -- & 1.600 & $\mathrm{D}$ & -- & 6,000 & -- & -- & 0.855 & $\mathrm{D}$ & -- \\
\hline \multirow[t]{10}{*}{$\mathrm{UC}_{2}$} & $5 \mathrm{Cr}$ & -- & -- & -- & -- & -- & -- & 26,000 & -- & 85 & 0.640 & 4.42 & D \\
\hline & $5 \mathrm{Fe}$ & -- & 38,000 & -- & 0.448 & -- & -- & 12,000 & -- & 124 & 0.555 & $\mathrm{D}$ & -- \\
\hline & $5 \mathrm{Mo}$ & -- & 88,000 & -- & 0.395 & -- & -- & 23,000 & -- & 80 & 0.540 & 0.209 & -- \\
\hline & $5 \mathrm{Nb}$ & 26,000 & 76,000 & 73 & 0.508 & -- & -- & 19,000 & -- & 76 & 0.438 & 7.00 & -- \\
\hline & $5 \mathrm{Nl}$ & 8,000 & 27,000 & 143 & 0.664 & -- & -- & 19,000 & -- & 271 & 0.824 & 1.31 & -- \\
\hline & $5 \mathrm{Ta}$ & - & 70,000 & 85 & 0.560 & $\mathrm{D}$ & -- & 7,000 & -- & 78 & 0.608 & $\mathrm{D}$ & -- \\
\hline & $5 \mathrm{Tl}_{1}$ & 18,000 & -- & 62 & 0.336 & -- & -- & 21,000 & -- & 59 & 0.376 & $\mathrm{D}$ & $D$ \\
\hline & $5 \mathrm{~V}$ & 32,000 & 106,000 & 69 & 0.385 & 0.23 & -- & 11,000 & -- & 93 & 0.612 & 0.23 & -- \\
\hline & $5 \mathrm{~W}$ & 35,000 & 145,000 & 77 & 0.558 & -- & -- & 31,000 & -- & 76 & 0.612 & +0.02 & -- \\
\hline & $5 \mathrm{Zr}$ & 31,000 & 62,000 & 88 & 0.418 & 0.284 & -- & 22,000 & -. & 80 & 0.447 & 42.7 & -- \\
\hline
\end{tabular}

(a) $\mathrm{D}=$ complete disintegration of specimen. 
F -8

TABLE F-3. COMPATIBILITY OF UC WITH SEVERAL ALLOYS

\begin{tabular}{|c|c|c|c|c|c|}
\hline \multirow[b]{2}{*}{ Material } & \multirow[b]{2}{*}{$\begin{array}{c}\text { Temperature, } \\
\text { C }\end{array}$} & \multirow[b]{2}{*}{$\begin{array}{c}\text { Time, } \\
\mathrm{hr}\end{array}$} & \multirow{2}{*}{$\begin{array}{c}\text { Optically Measured } \\
\text { Depth of } \\
\text { Penetration, in. }\end{array}$} & \multicolumn{2}{|c|}{$\begin{array}{l}\text { Knoop Hardness of } \\
\text { Metal Cladding }\end{array}$} \\
\hline & & & & $\begin{array}{c}\text { Reaction } \\
\text { Zone }\end{array}$ & $\begin{array}{l}\text { Unaffected } \\
\text { Zone }\end{array}$ \\
\hline \multirow[t]{3}{*}{ Inconel } & 1200 & 24 & 0.030 & -- & -- \\
\hline & 900 & 100 & 0.010 & 166 & 200 \\
\hline & 800 & 100 & 0.003 & 188 & 208 \\
\hline \multirow[t]{3}{*}{ Mild steel } & 1200 & 24 & 0.020 & -- & - \\
\hline & 900 & 100 & 0 & - & -- \\
\hline & 800 & 100 & 0 & 132 & 121 \\
\hline \multirow[t]{3}{*}{ Stainless steel } & 1200 & 24 & 0.010 & -- & -- \\
\hline & 900 & 100 & -- & - & -- \\
\hline & 800 & 100 & 0.005 & 247 & 167 \\
\hline \multirow[t]{3}{*}{ Zirconium } & 1200 & 24 & 0.030 & - & -- \\
\hline & 900 & 100 & 0.005 & -- & -- \\
\hline & 800 & 100 & 0.002 & 189 & 125 \\
\hline
\end{tabular}


Additional specimens of UC plus alloy additions of $\mathrm{Mo}_{2} \mathrm{C}, \mathrm{NbC}, \mathrm{TiC}$, and $\mathrm{VC}$ a re being prepared to determine more completely the effect of variations in alloy content on the properties of uranium monocarbide. The effect of annealing at various temperatures for various times on the microstructure of $U C, U_{2} C_{3}$, and $U_{2}$ is also being determined.

Work at other laboratories has shown that $\mathrm{ZrC}$ greatly improves the corrosion resistance of UC when prepared and alloyed by powder-metallurgy techniques. Previous work indicated that the $(U, \mathrm{Zr}) \mathrm{C}$ alloys could not be cast in unheated molds without cracking. Work is now in progress to determine if the casting properties of uraniumzirconium-carbon alloys can be improved by additions of $\mathrm{Mo}_{2} \mathrm{C}, \mathrm{TiC}$, or $\mathrm{VC}$.

\section{Uranium Monocarbide Diffusion Studies}

W. Chubb, R. W. Getz, and F. A. Rough

The rate of self-diffusion of uranium in uranium monocarbide is being studied using a tracer technique. The interest in the diffusion rates in uranium monocarbide is based on the potential utility of this material as a reactor fuel for high-temperature operation. Previously in this study, the rate of interdiffusion of carbon and uranium was determined using graphite and liquid uranium saturated with carbon in the temperature range from 1600 to $2000 \mathrm{C}$. Presently, the rate of self-diffusion of uranium in uranium monocarbide is being studied using a diffusion couple consisting of an enriched uranium foil sandwiched between two lengths of depleted uranium monocarbide rod. The couple is bonded for $4 \mathrm{hr}$ at $1400 \mathrm{C}$ followed by the diffusion anneal.

Using the gross-gamma counting method of analysis for enrichment, selfdiffusion coefficients for uranium in uranium monocarbide are being calculated. Although the results have not been sufficiently accurate to define the change in the selfdiffusion coefficient with temperature, they do establish the range of values to be expected. The results of the calculations are as follows:

\begin{tabular}{cc}
$\begin{array}{c}\text { Temperature, } \\
C\end{array}$ & $\begin{array}{c}\text { Self-Diffusion } \\
\text { Coefficient, } D, \\
\mathrm{~cm}^{2} \text { per sec }\end{array}$ \\
\cline { 2 - 2 } 1800 & $5 \times 10-10$ \\
1900 & $1 \times 10-9$ \\
2000 & $1 \times 10-8$ \\
2100 & $3 \times 10-9$
\end{tabular}

A couple annealed for $3840 \mathrm{~min}$ at $1600 \mathrm{C}$ was metallographically examined and appeared to be satisfactorily bonded and annealed. The couple will be sampled and analysed for uranium-235 content. couples.

Future work will include the preparation and analysis of additional diffusion 


\section{Irradiation Effects in UC}

A. E. Austin, D. G. Freas, C. M. Schwartz,

F. A. Rough, J. E. Gates, and R. F. Dickerson

An investigation of radiation-induced changes in the structural and physical properties of $\mathrm{UC}$ is presently in progress. The irradiation of one capsule in the BRR containing natural UC has been completed after an estimated burnup of $0.01 \mathrm{a} / \mathrm{o}$ of the uranium. A second capsule is presently being irradiated to an estimated burnup of $0.03 \mathrm{a} / \mathrm{o}$ of the uranium during three BRR cycles. The specimens in both of these capsules were immersed in $\mathrm{NaK}$ in order to maintain the specimens at an approximate center temperature of $180 \mathrm{~F}$. The specimens are composed of natural UC with a carbon content of about 4.9 w/o. The postirradiation examination of the specimens from both capsules is not expected to be completed until late July.

Additional irradiation experiments are presently being designed using specimens of 10 per cent enriched UC with carbon contents of $5.0,6.7$, and $8.5 \mathrm{w} / \mathrm{o}$. These irradiations will be conducted at both high and low temperatures to burnups of about 1 a/o of the uranium. The specimens for these experiments are being made by the arccasting technique. Preirradiation examination of the specimens will include measurements of dimensions, density, and electrical resistivity. X-ray and metallographic examinations and chemical analyses will also be included.

In support of these irradiation experiments, specimens are presently being prepared from natural uranium for thermal-stability and compatibility studies. These studies will provide a basis for selecting the proper heat treatments for irradiation specimens and will assist in the interpretation of any irradiation-induced changes. These preirradiation examinations and studies are expected to be completed so that the remaining four capsules of this program may be inserted in the BRR early in July. 
PHYSICAL RESEARCH (AEC-DR)

F. A. Rough

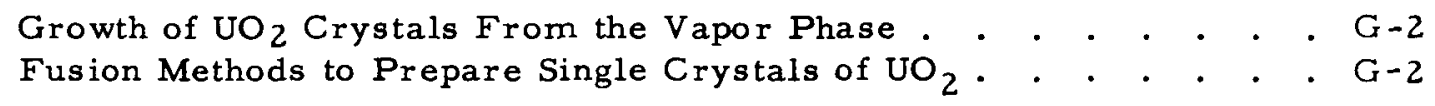

Projects of physical research being conducted for the AEC Division of Research ar reported in this section. Two projects concerned with the growth of high-purity singlecrystal $\mathrm{UO}_{2}$ are discussed this month.

Details of experiments are reported on the vapor deposition of $\mathrm{UO}_{2}$ by reaction of $\mathrm{UF}_{4}$ vapor and water vapor at $1050 \mathrm{C}$, by a solvent-evaporation method, and by congruen vaporization of $\mathrm{UO}_{2}$ near its melting point. Fusion experiments intended to purify $\mathrm{UO}_{2}$ by zone melting and to grow crystals by pulling from the melt are also in progress. 


\section{Growth of $\mathrm{UO}_{2}$ Crystals From the Vapor Phase}

C. A. Alexander and R. B. Filber, Jr.

Experiments were continued in producing single crystals of $\mathrm{UO}_{2}$ by the vapor-phase reaction of water vapor and $\mathrm{UF}_{4}$ and by crystal growth through evaporation of a molten halide solvent. Primary attention this past month was directed toward determining the effect of system pressure and water-vapor flow rate on the crystal growth rate and habit, and on the effect of admixtures on crystal habit in the solution-growth process.

An apparatus using vertical geometry and having a window was constructed for use in the vapor-phase growth, and it was determined that visible deposits of crystals were formed in about $4 \mathrm{hr}$. High rates of flow of water vapor $\left(10 \mathrm{~cm}^{3}\right.$ per min) favored the production of small cubic crystal agglomerates as did lowering of the system pressure to $0.1 \mathrm{~atm}$. In these runs there was microscopic evidence of inclusions of $\mathrm{UF}_{4}$ in the crystals. At very low flow rates of water vapor $\left(<1 \mathrm{~cm}^{3}\right.$ per $\left.\mathrm{min}\right)$, the crystal habit was dendritic, suggesting that $\mathrm{UF}_{4}(\mathrm{~g})$ condensed as $\mathrm{UF}_{4}$ liquid and that the growth was from the molten $\mathrm{UF}_{4}$. All the above experiments were performed at $1050 \mathrm{C}$, since at temperatures much below this the vapor pressure of $U F_{4}$ is too low to allow appreciable growth rates.

Crystals were also grown utilizing the prinicple of solvent evaporation. The solvent was $\mathrm{KF}$ to which was added 1 mole per cent to $\mathrm{FeCl}_{3}$. Results were somewhat encouraging in that many crystals in the size range of 2 to $3 \mathrm{~mm}$ were produced that had cubic symmetry without the dished top surface that had been obtained in previous runs using $\mathrm{KF}$ alone. These crystals appear under moderate magnification (150X) to be the most regular of any produced thus far.

For the coming month it is planned to further investigate the effect of time upon crystal growth in both the vapor-phase reaction and the solvent-evaporation process. In addition, it is planned to further investigate the effect of admixtures on solventevaporation crystal growth.

\section{Fusion Methods to Prepare Single Crystals of $\mathrm{UO}_{2}$}

W. P. Allred, J. D. Jackson, and B. Paris

Research on growth of crystals of $\mathrm{UO}_{2}$ during the month has concentrated on the horizontal resistance-heating method. The apparatus has been changed slightly to decrease the power requirements, make radiation shielding easier, and increase the maximum temperature obtainable and the length of time possible at high temperature. The tantalum shield necessary to cause a moving zone has been eliminated until the proper conditions for melting have been determined. The use of helium gas, passed through a liquid nitrogen trap, has been substituted for argon, which was used previously. This appears to eliminate the cloudiness on the sight glass, but an increase in power is required due to the larger thermal conductivity of helium. The tungsten heater is very susceptible to oxidation, and therefore sintered $\mathrm{UO}_{2}$ is used rather than compressed $\mathrm{UO}_{2}$ containing excess oxygen. It has been confirmed by $\mathrm{X}$-ray studies that metal transfer from the heater to the $\mathrm{UO}_{2}$ surface (presumably by decomposition of the tungsten oxide) can occur in some cases. 
The melting of $\mathrm{UO}_{2}$ is difficult to observe in this system, and the melting point appears to be much higher than previously thought. In one experiment, a pyrometer reading of $2600 \mathrm{C}$ (actual temperature estimated as $3000 \mathrm{C}$ ) was maintained for over $20 \mathrm{~min}$, with no visual indication of melting. However, when the power to the furnace was increased, the $\mathrm{UO}_{2}$ was driven from the heate $\mathrm{r}$ which then burned out. On examination, it was found that one edge of the bulk $\mathrm{UO}_{2}$ was fused to the outside of the heater. This material was polycrystalline and part of the surface appeared to be composed of vapor-deposited $\mathrm{UO}_{2}$, as evidenced by the growth of platelets.

The vapor pressure of $\mathrm{UO}_{2}$ is quite high near its melting point. An attempt to melt $\mathrm{UO}_{2}$ in a vacuum resulted in complete loss of the material. No indication of the time for complete evaporation could be determined, as tungsten metal transferred onto the $\mathrm{UO}_{2}$, forming a shell before all of the $\mathrm{UO}_{2}$ vaporized.

In another experiment, $\mathrm{UO}_{2}$ crystals were grown under helium by vapor deposition. A pyrometer reading of $2400 \mathrm{C}$ (actual temperature estimated, $2800 \mathrm{C}$ ) was maintained for $5 \mathrm{hr}$. Triangular-faced crystals about 60 mils on a side were grown in an intermediate area on the $\mathrm{UO}_{2}$ rod between the hot center section and the cooler ends. One crystal measured $90 \mathrm{mils}$ on a side. The growth of much larger crystals may be possible by conducting the experiment for longer periods. Such an experiment is planned.

Cursory examination of the vapor pressure of $\mathrm{UO}_{2}$ at its melting point is planned in addition to continued emphasis on the horizontal resistance heating. An experiment is being planned to melt $\mathrm{UO}_{2}$ in a tungsten-alloy crucible by induction heating and to pull a crystal from the melt. A thoria crucible has been obtained to replace the Alundum crucible which was melted in a previous experiment. 
RADIOISOTOPE AND RADIATION APPLICATIONS (AEC-OID)

D. N. Sunderman

Development of Radioactive-Tracer Quality-Control Systems
Use of Intrinsic Radioactive Tracers for Process Control

Two research programs in the area of radioisotope studies and one in radiation chemistry are under way for the Office of Isotopes Development. These are the development of radioactive-tracer quality-control systems, the use of intrinsic radioactive tracers for process control, and the study of radiation-induced graft polymerization.

An evaluation of a radiometric method for the determination of sulfate in portland cement is continuing. The lower limit of sulfate concentration for accurate measurement by this technique has been established. Initial experiments with standard cement samples indicate difficulties in the sample-preparation steps, and further experimentation is being directed to their correction.

The delivery of the pressure filter is delaying the completion of the process model for study of the intrinsic-tracer technique. Scheduled delivery early in May should allow experimental studies to be conducted before June 1, 1960. The evaluation of hydrometallurgical-process applications for intrinsic tracers is continuing with current emphasis on arsenic, iron, and tellurium removal from various electrolytic process solutions.

Chemical analyses of the radiolysis products of polybutylmethacrylate indicate that scission of the ester itself occurs along with ester-chain removal. Further analyses will be required to determine all reaction products. The formation of graft copolymexs between $\mathrm{N}$-vinyl-2-pyrrolidone and polymethylacrylate irradiated to maximum free-radical site concentration has begun. Results will be compared with previous data to relate site concentration and degree of grafting. 


\section{Development of Radioactive-Tracer Quality-Control Systems}

R. Lieberman, R. A. Ewing, and D. N. Sunderman

Radiometric techniques are being evaluated for application in the portland cement industry. During the past month, the lower limits of accurate measurement of sulfate were determined by precipitation of $\mathrm{Sr}^{89} \mathrm{SO}_{4}$. The sulfate analyses were performed on aqueous potassium sulfate solutions, and are summarized in Table $\mathrm{H}-1$. Work is under way to determine the sulfate content in portland cement samples.

T ABLE H-1. RESULTS OF SULFATE DETERMINATIONS

\begin{tabular}{|c|c|c|c|c|c|}
\hline Determination & $\begin{array}{c}\text { Initial Activity, } \\
\text { cpm }\end{array}$ & $\begin{array}{l}\text { Corrected } \\
\text { Final Activity, } \\
\text { cpm }\end{array}$ & $\begin{array}{c}\mathrm{K}_{2} \mathrm{SO}_{4} \text { Found, } \\
\text { mullimole }\end{array}$ & $\begin{array}{c}\mathrm{K}_{2} \mathrm{SO}_{4} \text { Added, } \\
\text { millimole }\end{array}$ & $\begin{array}{c}\text { Error, } \\
\text { per cent }\end{array}$ \\
\hline 1 & 3659 & 883 & 0.1044 & 0.1060 & -1.51 \\
\hline 2 & 3773 & 793 & 0.1083 & 0.1060 & +2.17 \\
\hline 3 & 3578 & 807 & 0.1065 & 0.1060 & +0.47 \\
\hline 4 & 1532 & 870 & 0.0237 & 0.0212 & +11.8 \\
\hline 5 & 2147 & 1554 & 0.0223 & 0.0212 & +5.19 \\
\hline $6^{(a)}$ & 2508 & 767 & 0.0191 & 0.0212 & -9.91 \\
\hline
\end{tabular}

(a) Specific activity of $\mathrm{Sr}^{89}\left(\mathrm{NO}_{3}\right)_{2}$ changed and less reagent used.

The cement sample was initially dissolved in dilutc $\mathrm{HCl}$. The solution was filtered to remove undissolved silica, and the filtrate was neutralized with ammonium hydroxide to precipitate the aluminum and iron hydroxides. The filtrate was treated with a prepared cation-exchange resin, Dowex 50, and the eluate was adjusted to $25 \mathrm{ml}$. A $10-\mathrm{ml}$ aliquot was used for the sulfate determination which was carried out by the method described in the last report (BMI-1430).

The sulfate content in cement is usually reported as $\mathrm{SO}_{3}$ and ranges from 1.3 to $1.8 \mathrm{w} / \mathrm{o}$. It was found that the analyses carried out to date gave low results, as shown in Table $\mathrm{H}-2$.

TABLE H-2. RESULTS OF SULFATE DETERMINATIONS ON PORTLAND CEMENT SAMPLES

\begin{tabular}{|c|c|c|c|c|c|}
\hline Determination & $\begin{array}{c}\text { Initial Activity, } \\
\text { cpm }\end{array}$ & $\begin{array}{c}\text { Corrected } \\
\text { Final Activity, } \\
\text { cpm }\end{array}$ & $\begin{array}{c}\mathrm{SO}_{3} \text { Found, } \\
\text { per cent }\end{array}$ & $\begin{array}{c}\mathrm{SO}_{3} \text { Decay, } \\
\text { per cent }\end{array}$ & $\begin{array}{c}\text { Error, } \\
\text { per cent }\end{array}$ \\
\hline 1 & 3074 & 2142 & 0.75 & $1.3-1.8^{(a)}$ & -- \\
\hline 2 & 3007 & 1435 & 0.69 & $1.3-1.8$ & - \\
\hline 3 & 3027 & 2190 & 0.86 & $1.55(\mathrm{~b})$ & -44.5 \\
\hline 4 & 3142 & 1965 & 1.07 & 1.55 & -30.9 \\
\hline
\end{tabular}

(a) Nominal range of $\mathrm{SO}_{3}$ per cent in typical portland cement sample of unknown composition.

(b) National Bureau of Standards Portland Cement Sample 177.

During the coming month attempts will be made to improve the accuracy of the method by determining where the loss of sulfate occurs. 
Use of Intrinsic Radioactive Tracers for Process Control

J. L. McFarling, P. Gluck, J. F. Kircher, and D. N. Sunderman

Construction of the process model for studying radiotracer-controlled iron removal is essentially complete, except for installation of the pressure filter. Shipment of the latter item has been postponed and is now scheduled for May 5, 1960.

The study of unit operations as potential radiotracer-control applications has been continued. However, the rate of effort has been reduced so that additional effort could be put on equipment construction.

Considerable time was spent this month on the survey of hydrometallurgical processes, which was begun last quarter. The electrolytic zinc process mentioned last month in BMI-1430 was considered in greater detail. Other processes studied this month included: copper refining, electrolytic manganese recovery, electrolytic chromium recovery, electrolytic lead refining, and electrolytic cadmium refining.

The following three potential applications of intrinsic radiotracers are considered to be the most promising ones considered this month:

(1) Removal of tellurium from zinc electrolyte solutions

(2) Removal of iron in the electrolytic manganese process

(3) Removal of arsenic in the electrolytic manganese process.

The extent of next month's work with the process-model system will depend upon the date of delivery of the filter. It is expected that some experimental runs will be performed with the completed system. The hydrometallurgical-process survey will be completed, and the unit-operations study will be continued at an increased rate of effort.

\section{Graft-Polymerization Studies}

I. S. Ungar, W. B. Gager, J. F. Kircher, and R. I. Leininger

During this month the investigation of the mechanism of formation and decay of radiation-induced free radicals in polymethacrylates continued. Some of the products of irradiated polybutylmethacrylates have been identified. It has been shown that the compounds formed are not only products of ester-chain removal and the addition of hydrogen with or without decarboxylation, but also arise from scission of the ester itself. For example, ethane, propane, n-butane, isobutane, carbon dioxide, ethyl formate, and propyl formate have thus far been identified in gamma-irradiated poly-nbutylmethacrylate in addition to butyl formate. Undoubtedly, methane, hydrogen, and possibly carbon monoxide are also present, but not detectable by the present procedure. In order to detect and measure the compounds formed during irradiation, known mixtures of compounds have been prepared as standards. From the retention times and amplitudes of these components a quantitative determination of the gaseous products will be made by vapor-phase chromatography. 
In another phase of the research, samples of the polymethacrylates were irradiated to their maximum site concentration as determined by the EPR spectrometer and grafted under vacuum with freshly distilled N-vinyl-2-pyrrolidone. The resultant mixture was fractionated to remove unreacted monomer, homopolymer, and unreacted polymer. The results will be compared with previously obtained data to determine the relationship between site concentration and degree of grafting.

Phenylmethacrylate was synthesized from methacrylchloride and sodium phenoxide. This monomer was polymerized according to the usual procedure. Samples of the polymer will be ir radiated next month, and site concentration for increasing dosage will be measured with the EPR spectrometer. These data will be compared with those of polycyclohexylmethacrylate to determine the effect of the aromaticity.

During the next month, work will continue on the investigation of the mechanism of radical formation and grafting in polymethacrylates. The products of irradiation will be further examined by gas chromatography. Infrared spectroscopy will be used wherever practicable to identify any unknown fractions. In addition, mass spectroscopy will be employed to measure low-molecular-weight fragments, such as hydrogen, carbon monoxide, and methane. The grafted polymers will be isolated, and the degree of grafting will be determined by nitrogen analysis. The results obtained from polyphenylmethacrylate will be evaluated. 


\title{
VOID-DISTRIBUTION AND HEAT-TRANSFER STUDIES (AEC-EURATOM)
}

\author{
D. V. Grillot, F. G. Peter, H. M. Epstein, and J. W. Chastain
}

Battelle is conducting a program to evaluate steam-void content and heat-transfer properties of light water in simulated reactor coolant channels. In past months the experimental apparatus has been constructed and experimental runs started.

During the past month test runs have continued, and preliminary analysis of the experimental results has begun. Accurate measurements of void fraction are now being obtained. At present, the volume of data obtained is not large enough to make any definite statements pertaining to the influence of certain parameters; however, it can be tentatively stated that the mass flow rate and operating pressure are significant parameters in determining the degree of negative quality and the magnitude of the void fraction in the subcooled region. The dependency of void fraction and negative quality on heat flux is at present uncertain.

It is anticipated that during the coming month all major work using the test section with a 50-mil channel thickness will be completed, and tests using a larger channel test section will be inaugurated. 
MATERIALS AND DEVELOPMENT AND EVALUATION (HAPO)

F. R. Shober

Mechanical Properties of Zirconium Alloys . . . . . . . . . . J-2

Development of Corrosion-Resistant Welding Alloys For Use With

Hastelloy $\mathrm{F}$ to Contain Decladding Solutions . . . . . . . . . J-2

The creep properties of Zircaloy- 2 are being investigated under a number of conditions of stress and temperatures. Zircaloy- 2 is being tested in both the annealed and cold-worked condition at 290,345 , and $400 \mathrm{C}$. In a program for development of corrosion-resistant welding alloys for use with Hastelloy $F$ to contain decladding solutions, twelve experimental nickel-base alloys were prepared and fabricated to $0.125-$ in. sheet. 


\section{Mechanical Properties of Zirconium Alloys}

L. P. Rice and J. A. VanEcho

This program is concerned with obtaining elevated-temperature creep data on Zircaloy-2 sheet material. Such information is essential in the design and safe operation of pressurized Zircaloy -2 process tubes. The NPR and the PRTR are also expected to utilize these data rather extensively.

Briefly, the over-all program at Battelle involves four phases which are being carried out simultaneously. All phases of the work are concerned with obtaining creep data on Zircaloy-2 sheet but under different sets of conditions. The four phases of the program are concerned with investigating:

(1) Long-time $(20,000 \mathrm{hr})$ creep properties of annealed Zircaloy-2 sheet at 290,345 , and $400 \mathrm{C}(550,650$, and $750 \mathrm{~F})$

(2) Long - and short-time creep and stress-rupture properties of 15 per cent cold-worked Zircaloy-2 sheet at 290, 345, and $400 \mathrm{C}$

(3) Creep properties of both annealed and 15 per cent cold-worked Zircaloy-2 sheet under cyclic-temperature conditions, with base temperatures of 290 and $345 \mathrm{C}$

(4) Creep properties of annealed and 15 per cent cold-worked Zircaloy-2 sheet under conditions whereby both temperature and stress are cycled, with base temperatures of 290 and $345 \mathrm{C}$.

During April, 20 creep machines were being utilized in this work. All tests reported in the March report (BMI-1430) were continued through April. Since most of the tests in this program are of a long-term nature, very little change occurs from one month to the next. As a result, no actual data are shown in this progress report. Current status of the program, with the exception of incremental time and strain added to each test, can be determined by referring to BMI-1430.

Development of Corrosion-Resistant Welding Alloys For Use With Hastelloy $\mathrm{F}$ to Contain Decladding Solutions

D. C. Drennen, R. E. Monroe, C. L. Peterson, P. D. Miller, A. M. Hall, and W. K. Boyd

Vacuum-induction melting of 12-1b heats of the experimental nickel-base alloys listed in Table $\mathrm{J}-1$ and subsequent fabrication of the ingots to annealed 0.125 -in. -thick strip were completed. 
TABLE J-1. FORGING AND ROLLING TEMPERATURES AND FABRICATION BEHAVIOR OF EXPERIMENTAL NICKEL-BASE ALLOYS

\begin{tabular}{|c|c|c|c|c|c|c|c|c|c|c|c|}
\hline \multirow{2}{*}{\multicolumn{2}{|c|}{ Alloy }} & \multirow[b]{3}{*}{$\mathrm{Ni}$} & \multirow{2}{*}{\multicolumn{5}{|c|}{ Nominal Addjtion ${ }^{(a)}, w / o$}} & \multicolumn{2}{|c|}{ Forging } & \multicolumn{2}{|c|}{ Hot Rolling (b) } \\
\hline & & & & & & & & \multirow{2}{*}{$\begin{array}{c}\text { Temperature, } \\
\text { F } \\
\end{array}$} & \multirow[b]{2}{*}{ Formability } & \multirow{2}{*}{$\begin{array}{c}\text { Temperature, } \\
\text { F } \\
\end{array}$} & \multirow[b]{2}{*}{ Formability } \\
\hline Final & Original & & $\mathrm{Cr}$ & Mo & Co & $\mathrm{Cu}$ & $\mathrm{Fe}$ & & & & \\
\hline 13 & 13 & 45 & 22 & 1.5 & -- & -- & 29.5 & 2125 & Very good & 2150 & Very good \\
\hline 14 & 14 & 45 & 22 & 4.5 & -- & -- & 26.5 & 2125 & Very good & 2150 & Very good \\
\hline 15 & 15 & 45 & 22 & 9 & -- & -- & 22 & 2125 & Very good & 2150 & Very good \\
\hline 16 & 16 & 45 & 22 & 9 & -- & 1 & 21 & 2125 & Very good & 2100 & Very good \\
\hline 17 & 17 & 50 & 25 & 1.5 & -- & -- & 21.5 & 2175 & Very good & 2150 & Very good \\
\hline 18 & 18 & 50 & 25 & 4.5 & -- & -- & 18.5 & 2175 & Very good & 2200 & Very good \\
\hline 19 & 19 & 50 & 25 & 6 & -- & -- & 17 & 2175 & Very good & 2200 & Very good \\
\hline 20 & $20 \mathrm{~A}$ & 50 & 25 & 6 & -- & 1 & 16 & 2175 & Good & 2100 & Good \\
\hline 21 & $21 A$ & 50 & 25 & 1.5 & -- & 3 & 18.5 & 2125 & Good & 2100 & Good \\
\hline 22 & 22 & 25 & 22 & 6 & 25 & -- & 20 & 2175 & Very good & 2150 & Very good \\
\hline 23 & 24 & 25 & $\begin{array}{c}25 \\
(24.7)\end{array}$ & $\begin{array}{c}9 \\
(5.4)\end{array}$ & 25 & $\cdots$ & 14 & 2200 & Fair & 2200 & Fair \\
\hline 24 & $24 \mathrm{~A}$ & 25 & 25 & 9 & 25 & -- & 14 & 2175 & Fair & 2200 & Fair \\
\hline-- & $20^{(c)}$ & 50 & $\begin{array}{l}25 \\
(24.7)\end{array}$ & $\begin{array}{c}6 \\
(4.3)\end{array}$ & -- & 1 & 16 & 2200 & Good & 2100 & Good \\
\hline-- & $21^{(c)}$ & 50 & $\begin{array}{l}25 \\
(25.2)\end{array}$ & $\begin{array}{l}1.5 \\
(0.86)\end{array}$ & -- & 3 & 18.5 & 2100 & Good & 2100 & Good \\
\hline-- & $23^{(c)}$ & 25 & $\begin{array}{l}25 \\
(24.8)\end{array}$ & $\begin{array}{l}6 \\
(3.8)\end{array}$ & 25 & -- & 17 & 2200 & Very good & 2200 & Very good \\
\hline
\end{tabular}

(a) Base contains $1 \mathrm{w} / \mathrm{o}$ titanium, $0.6 \mathrm{w} / \mathrm{o}$ manganese, $0.4 \mathrm{w} / \mathrm{o}$ silicon, and $0.02 \mathrm{w} / \mathrm{o}$ carbon. Parentheses indicate actual analyses.

(b) Alloys reheated to rolling temperature after each roll pass.

(c) This is one of the three off-composition alloys mentioned in BMI-1430. While information on workability is included here, no further evaluations of these three alloys are planned at this time. 
A standard melting practice, which consisted of heating the major elements tc $2600 \mathrm{~F}$, making the minor additions, and pouring the melt at $2600 \mathrm{~F}$, was used to prepare Alloys 20, 21, 23, and 24: However, a different melting practice was employed for the remaining alloys. This consisted of (1) heating the major elements to $3000 \mathrm{~F}$ and holding for $10 \mathrm{~min}$, (2) lowering the temperature of the melt to $2750 \mathrm{~F}$ and making the minor element additions, and (3) pouring the melt at 2750 . As a result of the higher pouring temperature, the buildup in the crucible was noticeably reduced.

The forging and rolling temperatures given in Table J-1 were determined from preliminary studies conducted on pilot ingots of the alloys. In general, the fabrication behavior of the alloys, as indicated in Table $\mathrm{J}-1$, was very good. However, in the case of Alloys 20,20A, 21, and $21 \mathrm{~A}$, there was evidence of hot cracking during hot working at temperatures above $2100 \mathrm{~F}$; therefore, a temperature of $2050 \mathrm{~F}$ is recommended for these alloys. The poorest fabricability was exhibited by Alloys 24 and $24 \mathrm{~A}$, which developed moderate edge and corner cracks during the forging and rolling operations.

On the basis of the results of the annealing study performed on the first series of alloys, a solution-annealing temperature of $2050 \mathrm{~F}$ was selected for all of the alloys. The hot-rolled alloys were annealed $1 \mathrm{hr}$ at this temperature and water quenched. Provided the results of the metallographic examination are satisfactory, the annealed alloys will be evaluated for welding, and self-welded specimens will be exposed to Niflex and Sulfex decladding solutions. In the meantime, chemical analyses of a few selected alloys and hardness data for all of the alloys a re being obtained. 


\section{PREPARATION OF ALUMINUM-URANIUM ALLOYS (SCL)}

N. E. Daniel, E. L. Foster, R. F. Dickerson, and R. J. Carlson

Aluminum-uranium alloys containing up to $35 \mathrm{w} / \mathrm{o}$ uranium are desired for certain nuclear-reactor applications in the form of tubular fuel elements. It appears to be possible to decrease casting and fabrication difficulties in these alloys by the use of ternary additions such as tin or zirconium. In this research program, the effect of additions of up to $3 \mathrm{w} / 0$ of the se elements on the physical properties and corrosion resistance of the aluminum-uranium alloys is being studied.

Stress-rupture data from tests of up to $100 \mathrm{hr}$ in duration at $200 \mathrm{C}$ were reported last month (BMI-1430). Currently, tests are being made for approximately 400 to $600 \mathrm{hr}$ at $200 \mathrm{C}$ using stresses estimated to cause rupture of the specimens in about $500 \mathrm{hr}$. These stresses were obtained by extrapolation of the previous stress-rupture data. A list of the alloys being tested and the stresses being imposed are presented below.

\begin{tabular}{lcc} 
Ingot & $\begin{array}{c}\text { Composition } \\
\text { (Balance Aluminum), w/o }\end{array}$ & $\begin{array}{c}\text { Test Stress, } \\
\text { psi }\end{array}$ \\
\cline { 2 - 2 } 113 & $35 \mathrm{U}$ & 9200 \\
106 & $35 \mathrm{U}-3 \mathrm{Sn}$ & 5800 \\
118 & $35 \mathrm{U}-3 \mathrm{Zr}$ & 6500 \\
$122(\mathrm{a})$ & $35 \mathrm{U}-2 \mathrm{Zr}$ & 8000 \\
$123($ a) & $35 \mathrm{U}-3 \mathrm{Zr}$ & 7500
\end{tabular}

(a) These alloys were melted in vacuum; all other alloys were melted in air.

Limited efforts have been expended in the preparation of two tubular castings of aluminum-25 w/o uranium with either a ternary addition of $3 \mathrm{w} / 0$ tin or $3 \mathrm{w} / \mathrm{o}$ zirconium. These are to be fabricated and evaluated at another site. The initial attempts to prepare the zirconium alloy were successful. However, segregation difficulties were experienced with the $3 \mathrm{w} / \mathrm{o}$ tin alloy, even though the alloy was cast in a cold mold from a rotating pouring cup.

Future work will be restricted to the completion of the stress-rupture tests. 


\section{REFLECTIVE-INSULATION ST UDIES (KAISER)}

L. J. Flanigan, G. R. Whitacre, G. W. Pfannebecker, J. D. Hummell, and H. R. Hazard

Studies of reflective insulating materials suitable for use in the Experimental GasCooled Reactor are being conducted at Battelle. To determine suitability, the material will be subjected to repetitive thermal cycling and rapid decompression, and measurements will be made to determine its insulating value. Previously reported work includes completion of the detail design of the heat-transfer apparatus, the decompression chamber, and the thermal-cycling equipment and partial construction of the equipment.

In April, construction of the decompression chamber was completed and construction was continued on the thermal-cycling equipment and the heat-transfer apparatus. The estimated completion date for the thermal-cycling equipment is May 10 and that for the heat-transfer apparatus is May 15.

Samples of reflective insulation suitable for study in the equipment being constructed are to be supplied by two manufacturers. The Budd Company estimates that its samples will be ready by May 15. Johns Mansville estimates that a sample for decompression and thermal cycling will be ready by June 1, with the two-heat transfer samples to follow at 10-day intervals. The Mirror Insulation Company has decided not to submit samples.

In May, the remaining construction will be completed and evaluation studies started. 


\title{
PROBLEMS ASSOCIATED WITH THE RECOVERY OF SPENT REACTOR FUEL ELEMENTS (ORNL)
}

\author{
C. L. Peterson and R. A. Ewing
}

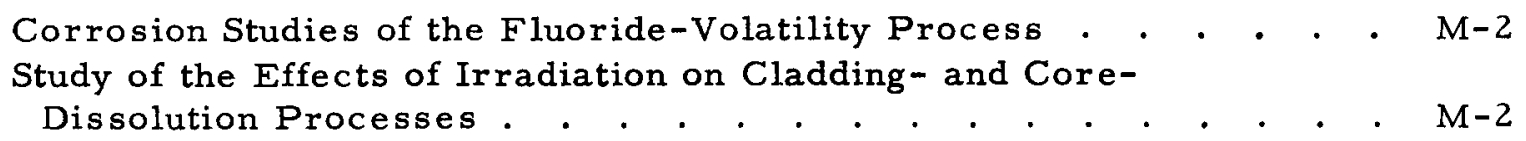

Metallographic evaluations of the corrosion which occurred on miniature fluorinators with walls of $\mathrm{Hy} \mathrm{Mu} 80$ and bottom plates and sparge tubes of "A"-Nickel showed Hy $\mathrm{Mu} 80$ to be the more resistant of the two metals under the conditions of the experimental runs. The fluorinations had been conducted at ORNL with $\mathrm{NaF}-\mathrm{ZrF}_{4}$ and $\mathrm{NaF}-\mathrm{LiF}-\mathrm{ZrF}_{4}$ molten-salt systems.

Losses of $\sim 0.02$ per cent of the thorium and $\sim 0.3$ per cent of the uranium from Consolidated Edison fuel ( $\left.\mathrm{UO}_{2} .3\right)$ to Sulfex decladding solutions have been confirmed. Initial dissolutions of "cold" CETR fuel pins are under way. 


\title{
Corrosion Studies of the Fluoride-Volatility Process
}

\author{
P. D. Miller, C. L. Peterson, W. K. Boyd, \\ W. N. Stiegelmeyer, and F. W. Fink
}

Six miniature fluorinators made from $\mathrm{Hy} \mathrm{Mu} 80$ were used in experiments at ORNL and then sent to BMI for a corrosion evaluation by metallography. The containers had been charged with $\mathrm{NaF}-\mathrm{ZrF}_{4}$ and $\mathrm{LiF}-\mathrm{NaF}-\mathrm{ZrF}_{4}$ salt compositions, with and without $\mathrm{UF}_{4}$ additions. The fluorinators were operated in the temperature range 500 to $600 \mathrm{C}$; sparged first with helium and then with fluorine. The fluorine sparge lasted for $50 \mathrm{hr}$ out of a total time at temperature varying from 100 to $150 \mathrm{hr}$.

The average metal loss from the walls of the Hy $\mathrm{Mu} 80$ fluorinators varied from about 1 to 4 mils. The loss from the "A"-Nickel sparge tubes and bottom plates varied from 1 to 8 mils. Each material showed some evidence of intergranular attack on both the salt side and air side. The maximum intergranular attack on the nickel was about 20 mils, and on the Hy Mu 80 it was about 3 mils.

The present study indicates that "A"-Nickel was somewhat less resistant than Hy $\mathrm{Mu} 80$ to the fluorination conditions used during these runs.

Study of the Effects of Irradiation on Cladding - and Core-Dissolution Processes

R. A. Ewing, H. B. Brugger, and D. N. Sunderman

\section{Sulfex Process}

Sulfex dissolutions have been completed on two "cold" Consolidated Edison prototype fuel pins. Cumulative thorium and uranium losses, based on small "grab" samples taken during the decladding, are shown in Table $\mathrm{M}-1$.

TABLE M-1. THORIUM AND URANIUM LOSSES DURING DECLADDING

\begin{tabular}{ccccc}
\hline \multirow{2}{*}{$\begin{array}{c}\text { Decladding Time, } \\
\text { hr }\end{array}$} & \multicolumn{4}{c}{ Loss, per cent } \\
\cline { 2 - 5 } & \multicolumn{2}{c}{ Sulfex Run C-7 } & \multicolumn{2}{c}{ Sulfex Run C-8 } \\
\cline { 2 - 4 } 3 & 0.010 & Thorium & Uranium \\
5 & $--(a)$ & 0.35 & 0.010 & 0.17 \\
8 & 0.011 & $--(a)$ & 0.013 & 0.32 \\
12 & 0.022 & 0.34 & 0.015 & 0.30 \\
16 & 0.016 & 0.38 & 0.021 & 0.31 \\
20 & -- & 0.34 & 0.023 & 0.42 \\
24 & -- & -- & 0.027 & 0.35 \\
& & -- & 0.032 & 0.40 \\
\hline
\end{tabular}

(a) No 5-hr sample taken. 
Neither thorium nor uranium losses increased rapidly when the dejacketed core pellets were refluxed with the cladding solutions for prolonged periods under a nitrogen atmosphere. The relatively high uranium losses may be attributable to the oxygen:uranium ratio in the se cores, reportedly $\mathrm{UO}_{2.3}$. Measured densities of core pellets varied between 8.68 and $8.94 \mathrm{~g}$ per $\mathrm{cm}^{3}$, about 89 to 92 per cent of theoretical.

About 70 per cent of the core was dissolved in the first 6-hr pass in Sulfex Run C-8, confirming the results of Sulfex Run C-7. With a core dissolvent: core ratio of $10 \mathrm{ml}$ per $\mathrm{g}$, the remaining 30 per cent was dissolved in a second 6 -hr pass.

Fuel pins currently being investigated are high-density low oxygen: uranium ratio ( $\sim \mathrm{UO}_{2} .0$ ) Consolidated Edison prototype specimens (CETR pins), which have just been released from postirradiation studies. A Sulfex dissolution of a duplicate unirradiated specimen is now in progress to establish dissolution conditions for the ir radiated specimens. Dissolution tests of irradiated pins are scheduled in May.

A limited investigation is in progress to identify and measure the individual isotopes contributing to the gamma activities of the solutions obtained from previous dissolutions of ORR-irradiated Consolidated Edison prototype fuel pins. Samples of several core solutions have been separated into fractions by a solvent-extraction procedure using thenoyltrifluoroacetone. Gamma spectroscopy of these fractions indicated that cerium-14l was the major source of gamma activity; zirconium-95 and niobium -95 were but minor contributors. On the basis of the semiquantitative data so far available, percentages of the fission products reporting in the cladding solutions were low. More quantitative data on both cladding and core solutions are to be obtained with the aid of a multichannel gamma spectrometer just received.

\section{Darex Process}

No Darex dissolutions were conducted during the month. Two "cold" and three "hot" Darex dissolutions of CETR pins are scheduled over the next several months. 


\section{VARIABLE-MODERATOR REACTOR CRITICAL-ASSEMBLY STUDIES (ATL-A)}

R. A. Egen, L. H. Bettenhausen, W. S. Hogan, D. A. Dingee, and J. W. Chastain

A critical-assembly experiment is being conducted for the Advanced Technology Laboratories of American Standard Corporation as a part of a program to study the Variable-Moderator Reactor concept. During the month, criticality was attained for the first time after several weeks of subcritical experimentation.

Two core configurations with 37 fuel elements, each containing 61 fuel pins of aluminum-clad 1.8 per cent enriched $\mathrm{UO}_{2}$, have been investigated. The fuel pins were a ranged in a triangular configuration with a center-to-center spacing of 0.633 in. Two triangular arrangements of fuel elements have been investigated with spacings of $5.54 \mathrm{in}$. and $5.95 \mathrm{in}$. on center. The coolant-simulating material and the moderator were roomtemperature water in both cases.

Using new techniques a series of reactivity measurements were made to evaluate changes in water heights in both configurations. In the configuration with the 5.54-in. fuel-element pitch, detailed flux and power distributions were measured and experimental data for evaluating resonance escape probability and fast-fission effect were obtained. The temperature coefficient of reactivity was also determined for this core.

In May void coefficients of reactivity will be measured in the coolant region of the first configuration (5.54-in. fuel-element spacing) using furfural and furfuryl alcohol for void simulation. In addition, the nuclear parameters previously mentioned will be measured for other core configurations. 
URANIUM CARBIDE AS A REACTOR FUEL (AI)

E. L. Foster

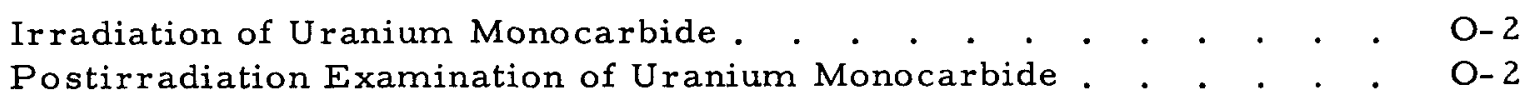

The center-line temperature of Capsule BMI-23-4, being irradiated at the MTR, continues in the 1000 to $1100 \mathrm{~F}$ range. It is scheduled for discharge at the end of Cycle 140 (mid-June, 1960) with a total irradiation of 26 MTR cycles. The target burnup is $20,000 \mathrm{MWD} / \mathrm{T}$ of uranium.

Additional burnup values for the materials examined to date have been obtained. Specimens of UC from Capsule BMI-23-6 were analyzed, and the burnup was determined to be $6570 \mathrm{MWD} / \mathrm{T}$ by Cesium-137 analysis and $7100 \mathrm{MWD} / \mathrm{T}$ by uranium-236 analysis. 
O- $\underline{2}$

\section{Irradiation of Uranium Monocarbide}

D. Stahl, J. H. Stang, and W. H. Goldthwaite

During April, specimen center-line temperatures for Capsule BMI-23-4, which contains uranium monocarbide specimens, were in the 1000 to $1100 \mathrm{~F}$ range. The capsule is scheduled for discharge from the MTR at the end of Cycle 140 (mid-June, 1960) for a total irradiation of $26 \mathrm{MTR}$ cycles and a target burnup of 20,000 MWD/T of uranium.

\section{Postirradiation Examination of Uranium Monocarbide}

S. Alfant, A. W. Hare, and R. F. Dickerson

At this time, five capsules containing cylindrical specimens of UC have been irradiated at the MTR and returned to $B M I$ for postirradiation examination. Capsule BMI-23-4 is now being irradiated at the MTR in Position A-27-SE for a target burnup of approximately 20,000 MWD/T of uranium, and is scheduled for discharge at the end of MTR Cycle 140 for a total irradiation of 26 cycles.

Examination of Capsule BMI-23-6 was completed at the BMI Hot-Cell Facility and the results were reported previously. During the past month an isotopic analysis for uranium-236 was completed on a specimen from Capsule BMI-23-6 to determine the burnup. In addition, a burnup based on Cesium-137 analyses of the se specimens was calculated. The burnup results are tabulated below:

Analysis Method

Cesium -137

Uranium - 236

\begin{tabular}{lc}
\multicolumn{2}{c}{ Uranium Burnup } \\
\hline a/o & MWD/T \\
\cline { 2 - 2 } 0.72 & 6570 \\
0.77 & 7100
\end{tabular}

No further work is planned until Capsule BMI-23-4 arrives at the BMI Hot-Cell Facility for postirradiation examination. 
W. S. Diethorn

Laboratory Development of Fueled-Graphite Spheres . . . . . . . P-2

Fabrication Development of Coated Fuel Particles . . . . . . . . P-2

Subsurface Coatings . . . . . • . . • . . . . . . . . . P-2

Fission-Product Release From Fueled-Graphite Spheres . . . . . P-3

Neutron-Activation Studies . . . . . . . . . . . . . P-3

In-Pile Capsule Experiments . . . . . . . . . . . . . P-3

Battelle is investigating the mechanical properties, radiation damage, and fissiongas release of 1.5-in. -OD fueled-graphite spheres in support of the Pebble-Bed Reactor program. Fuel-element development in the Battelle program consists of an exploratory fabrication study of subsurface coatings in fueled graphite, and the development of coated fuel particles.

A 50-hr self-welding test with siliconized SiC-coated fueled-graphite spheres at $2300 \mathrm{~F}$ revealed no self-welding under a compressive load of $50 \mathrm{lb}$. Several batches of carbon-coated $\mathrm{UC}_{2}$ particles prepared this month show poor resistance to severe thermal shock. Encouraging results have been obtained in the fabrication study of subsurface coatings, but additional work is needed to evaluate this concept of a coatedgraphite fuel element. The high-flux sweep capsule, SP-5, was inserted in the BRR during April. During the 20-day capsule operating period this month the siliconized $\mathrm{SiC}$-coated sphere showed excellent fission-gas retention at $1300 \mathrm{~F}$. The $\mathrm{R} / \mathrm{B}$ for this specimen is $1 \times 10^{-9}$. 
M. C. Brockway and A. K. Smalley

The evaluation of coated fueled-graphite spheres supplied by commercial vendors is continuing. Impact and compression tests, metallography, gross coating porosity, and self-welding tests are the chief efforts of this laboratory study. A $50-h \mathrm{r}$ selfwelding test was conducted with two siliconized SiC-coated spheres at $2300 \mathrm{~F}$ under a lead of $50 \mathrm{lb}$. There was no evidence of self-welding. A slight crushing of the coating was observed at the point of sphere contact. A white film was formed on the coating during the test. It is hoped that $\mathrm{X}$-ray analysis will reveal the nature and source of the film.

\section{FABRICATION DEVELOPMENT OF COATED FUEL PARTICLES}

A. C. Secrest, J. H. Oxley, and J. M. Blocker

Two samples of minus 60 plus $80-$ mesh $\mathrm{UC}_{2}$, one coated with $17 \mu$ and the other with $40 \mu$ of carbon, were prepared this month. Both coatings failed when thermal cycled between room temperature and $2000 \mathrm{C}$ in an argon atmosphere, as shown by nitric acid leach tests, alpha assays, and microscopic examination.

Soot formation in the fluidized-bed reactor frequently prevents continuous application of thick coatings. At present, the coating is deposited in steps, giving a layered coating structure. A uniform coating structure may have better thermal-shock resistance. Attempts are being made to reduce soot formation to avoid layered coatings.

Future work will consist of depositing carbon at higher temperatures in an attempt to improve coating integrity during thermal cycling.

\section{SUBSURFACE COATINGS}

\section{A. J. Roese, W. C. Riley, and W. H. Duckworth}

One method of retaining fission products in a spherical graphite fuel element is to place a subsurface coating or seal between the fueled graphite and an unfueled graphite shell. As reported last month in BMI-1430, an exploratory study of fabrication problems is under way.

Hot pressing has been investigated as a technique for forming subsurface seals. Seal materials, in powder form, were cold pressed on fueled inner spheres, and an unfueled graphite shell was cold pressed around the coated sphere. The cold-formed body was hot pressed in a graphite die using a pressure of 5 tsi on the die. Spheres containing copper, nickel, silicon, and high-barium glass seals were pressed at the melting point of the seal materials. Spheres containing MoSi2, chromium and titanium 
were hot pressed at about $2000 \mathrm{~F}$. Subsequently, these latter spheres were heat treated to the melting point of the seal materials in a carbon resistor furnace.

Visual inspection of sectioned spheres showed that each seal material, except copper, formed a continuous layer. Copper beaded. Cracks were observed in the shells of specimens containing $\mathrm{MoSi}_{2}$, chromium, and titanium seals. These three seals were melted without pressure. The seal material appeared to flow into the cracks. No cracks appeared in specimens that were under pressure during seal melting. Radiography showed that all seal materials penetrated into the unfueled graphite shell.

Hot-oil tests were expected to reveal gross differences in seal merit among the specimens because the unfueled shell rather than the entire sphere is the source of desorbed gas when the seal is good. Short bubble-evolution times were observed with the $\mathrm{MoSi}_{2}$, chromium and titanium specimens in spite of crack formation in the shells. From the available information, these three seal materials show the most promise. Higher hot-pressing temperatures may eliminate shell cracking.

The results of this exploratory program are encouraging, but fabrication problems need further study. No work on this program is planned next month.

\section{FISSION-PRODUCT RELEASE FROM FUELED-GRAPHITE SPHERES}

W. S. Diethorn

Fission-Gas release from fueled graphite and coated fuel particles is being investigated in (1) postirradiation heat-treatment studies of neutron-activated specimens (2) low-flux furnace capsules, and (3) high-flux sweep capsules.

\section{Neutron-Activation Studies}

H. S. Rosenberg

There is nothing to report this month.

\section{$\underline{\text { In-Pile Capsule Experiments }}$}

D. Stahl, G. E. Raines, R. J. Burian, and W. H. Goldthwaite

$\underline{\mathrm{SP}-4}$ May.

Completion of the postirradiation examination of $\mathrm{SP}-4$ specimens is expected in 
The high-flux sweep-capsule experiment, SP-5, was inserted into a BRR core position on April 7, 1960. A detailed specimen description and capsule objectives were presented in last month's report (BMI-1430). During April, this capsule operated about 20 days. Graphite Sphere FA-23, E8-7, containing $4.7 \mathrm{~g}$ of fully enriched 100 to $150-\mu \mathrm{UC}$, is operating at surface and center temperatures of 1300 and $1500 \mathrm{~F}$, respectively. This sphere is coated with $8 \mathrm{mils}$ of siliconized SiC. The heat-generation rate in this sphere is $1.6 \mathrm{kw}$. The other five capsule specimens are running at about the same surface temperature $(1300 \mathrm{~F})$.

The R/B data for the FA-23, E8-7 sphere are reported in Table P-1. Gas samples are collected for 2 to $3 \mathrm{hr}$ each. Fission-gas retention is excellent. It is planned to operate this capsule for several months.

TABLE P-1. SUMMARY OF FA-23 FISSION-GAS DATA

\begin{tabular}{|c|c|c|c|c|c|c|}
\hline \multirow{2}{*}{$\begin{array}{c}\text { Sample } \\
\text { Collection } \\
\text { Date } \\
\end{array}$} & \multirow[b]{2}{*}{ Sample } & \multicolumn{5}{|c|}{$R / B(a)$} \\
\hline & & Krypton-85m & Krypton-87 & Krypton-88 & Xenon-133 & Xenon-135 \\
\hline $4 / 21$ & 1 & $\mathrm{Nil}^{(\mathrm{b})}$ & Nil & $\mathrm{Nil}$ & Nil & Ni1 \\
\hline $4 / 22$ & 2 & Nil & $\mathrm{Nil}$ & Nil & Nil & Nil \\
\hline $4 / 26$ & $3^{(c)}$ & $1.2 \times 10^{-9}$ & Ni1 & $0.7 \times 10^{-9}$ & $2.6 \times 10^{-9}$ & $0.7 \times 10^{-9}$ \\
\hline
\end{tabular}

(a) $R=$ number of atoms released per second from the sphere.

$B=$ number of atoms generated per second in the sphere.

(b) Below sensitivity of fission-gas analysis.

(c) Collected for $22 \mathrm{hr}$.

$\mathrm{SPF}-3$

The terminated SPF-3 furnace-capsule experiment will be continued when the new gas train is ready. Operation of SPF-3 is expected in June. 


\title{
TANT ALUM AND TANT ALUM ALLOYS FOR LAMPRE APPLICATIONS (LASL)
}

\author{
J. H. Stang
}

Development of Container Materials for LAMPRE Applications . . . . Q-2 Precipitate Phase Identification and Interstitial-Type Solid Solubility in Tantalum . . . . . . . . . . . . . . . . . . Q-2

The investigations reported in this section are in support of the LAMPRE program at Los Alamos Scientific Laboratory. Standard arc-melting and strip-processing operations on two groups of tantalum-base alloys continued during April. Further phaseidentification studies were carried out on the tantalum-oxygen system; similar studies are under way on the tantalum-nitrogen and tantalum-carbon systems. 
D. C. Drennen, C. J. Slunder, and J. G. Dunleavy

Information recently gained from examinations of the microstructures of a group of binary tantalum-base alloys in the as-cast condition is presented in Table Q- 1 . Buttons of these materials are being processed to 0.030-in. strip; specimens from the strip will be forwarded to Los Alamos for plutonium-alloy corrosion evaluations.

Melting and strip-processing operations on another group of tantalum-base materials listed in BMI-1430 are in progress. Detailed examinations of the materials (metallographic analyses, chemical analyses to determine purity levels, etc.) are under way.

\section{Precipitate Phase Identification and Interstitial-Type Solid Solubility In Tantalum}

D. A. Vaughan and C. M. Schwartz

$\mathrm{X}-\mathrm{ray}$ diffraction and metallographic examinations are being carried out on the tantalum-oxygen, -nitrogen, and -carbon systems to determine the solid solubilities of these interstitials at 500,1000 , and $1500 \mathrm{C}$ and to identify the initial precipitate phases in the binary systems. Previous reports have dealt with the effect of oxygen solid solution on the expansion of the tantalum lattice. Gas-solid reactions have been employed to prepare specimens containing up to 2 a/o oxygen. Attempts have been made to prepare specimens of higher oxygen content by this method. However, analyses after homogenization at $1800 \mathrm{C}$ and annealing at $1500 \mathrm{C}$ have shown that 2 a/o is the maximum oxygen retained by the specimen. It appears that oxide formed at higher oxygen levels is volatilized, at least in part, during the vacuum-homogenizing and -annealing treatments. It is planned to prepare higher oxygen alloys by arc-melting methods.

During the past month the analyses of the initial tantalum-nitrogen and tantalumcarbon specimens were initiated. In the case of tantalum-nitrogen considerable difference was found between the intended addition and the analysis. Additional tantalumnitrogen specimens are being prepared. In the case of tantalum-carbon specimens, the solid solubility at $1500 \mathrm{C}$ appears to be very low, of the order of $0.2 \mathrm{a} / \mathrm{o}$. A specimen reacted with 1.45 a/o carbon contained a second phase which has been identified as $\mathrm{Ta}_{2} \mathrm{C}$ by X-ray diffraction. Further study of the tantalum-carbon system will be directed toward lower carbon additions. However, one arc melt of higher carbon content is being prepared. 
TABLE Q-1. MICROSTRUCTURE DATA FOR A GROUP OF TANT ALUM ALLOYS IN THE AS-CAST CONDITION

Alloy

$\mathrm{Ta}-0.5$ to $6 \mathrm{w} / 0 \mathrm{Th}$

$\mathrm{Ta}-1 \mathrm{w} / \mathrm{O}$ and $-3 \mathrm{w} / \mathrm{O} \mathrm{Si}$

$\mathrm{Ta}-0.5 \mathrm{w} / \mathrm{o},-1.5$, and -3.0

$\mathrm{Ta}-\mathrm{Fe}$

Ta-Hf

Unalloyed Ta (control)
Inter- and intragranular phase increasing in amount with increasing thorium content; possible grain refinement with increasing thorium content

Heavy, rather large dendritic second phase; 3 w/o silicon alloy has more, but smaller dendrites; no distinct grain boundaries in either composition

No second phase in $0.5 \mathrm{w} / \mathrm{o}$ zirconium alloy; slight amount of second phase at grain boundaries in $1.5 \mathrm{w} / \mathrm{o}$ zirconium alloy; fairly heavy intergranular second phase in $3.0 \mathrm{w} / \mathrm{o}$ zirconium alloy; grain refinement with increasing zirconium additions

Single-phase, large-grained structure

Ditto

Ditto 


\title{
FLOW STUDIES FOR THE PWR (BAPD)
}

\author{
H. R. Hazard and L. J. Flanigan
}

This is the first report summarizing flow studies for PWR Core 2. Under this program, a 0.4-scale model of the reactor is to be designed and constructed, and a series of flow studies is to be carried out. The internal dimensions of the reactor vessel, thermal shields, hold-down barrel, and flow baffle will be accurately modeled. The core structure will use round tubes to simulate fuel assemblies. The interpass region, between the first pass and second pass of the core, will be accurately modeled. Core pressure drops will be obtained by use of orifices in tubes simulating the fuel assemblies, and the same orifices will be used to measure flow and flow distribution. Flow studies will be carried out using air at about 9 lb per sec and 4 psi.

On April 8, preliminary drawings of each of nine large parts, which are to be made of glass-fiber-reinforced epoxy resin, were distributed to four plastic fabricators during a conference at Bettis. These drawings were traced from reactor prints, and dimensions were approximate. However, all instrumentation and all tolerances were shown, to provide a basis for satisfactory cost estimates. On the basis of proposals submitted, the Accurate Plastic Tooling \& Pattern Co., Inc., was selected by Bettis to construct the parts.

On April 15 and 26, preliminary drawings showing final dimensions of the principal parts were released to Bettis and to Accurate, and final drawings are being released as they are completed. Completion of all drawings for plastic parts is scheduled for May 6.

In May, drawings for all plastic parts will be completed, and the aluminum core will be designed. 
DEVELOPMENT OF MATERIALS FOR THE MGCR AND HTGR (GA)

W. C. Riley

High-Burnup Irradiation Effects in Fuel Materials . . . . . . . S-2

Thermal Conductivity of Beryllia . . . . . . . . . . . . S-2

Preparation and Coating of Uranium and Thorium Carbide Powders . S-4

Research on core materials for both the MGCR and HTGR is in progress. For the MGCR, the major effort is on development and evaluation of $\mathrm{UO}_{2}$ dispersions in $\mathrm{BeO}$ and $\mathrm{Al}_{2} \mathrm{O}_{3}$ and dispersions of $\mathrm{UC}$ or $\mathrm{UC}_{2}$ in graphite. Currently, the evaluation consists mainly of static-capsule irradiation in the MTR. In addition, an apparatus for measurement of thermal conductivity of fueled and unfueled beryllia is being prepared.

For the HTGR, vapor deposition is being investigated as a method of preparing and coating uranium and thorium carbide powder. 
High-Burnup Irradiation Effects in Fuel Materials

W. E. Murr, N. E. Miller, J. E. Gates, and R. F. Dickerson

Ceramic type fuels composed of about 20 volume per cent uranium dioxide in beryllium oxide, 20 volume per cent uranium monocarbide in graphite, and 20 volume per cent uranium dicarbide in graphite are being investigated for use as potential fuels for the MGCR. A program is in progress that is designed to study the irradiation stability of these fuels at specimen-surface temperatures of about $1500 \mathrm{~F}$. The program consists of the irradiation and postirradiation examination of 24 fuel specimens contained in 4 capsules, each equipped with heaters and thermocouples. Two specimens of each of the three fuel compositions were included in each capsule. The specimens are composed of four fuel pellets, each approximately 0.222 in. in diameter by 0.250 in. long, encased in Type 316 stainless steel.

The irradiation of the first capsule ( 1.1 to 1.7 uranium a/o burnup) and the postirradiation examination of the specimens have been completed. The results of the examination of the specimens were reported in detail in BMI-1366 and BMI-1377.

The three remaining capsules have been in operation in the MTR since July 24 , 1959 (beginning of Cycle 125). To date the capsules have operated successfully for 12 MTR irradiation cycles. All three heaters in each capsule are still operating, and three thermocouples in Capsules BMI-31-1 and BMI-31-2 and four thermocouples in BMI-31-3 remain operational. Individual specimen temperatures and capsule-heater power requirements for maintaining specimens in the desired temperature range (1500 F) are reported in Table S-1 for the beginning of MTR Cycle 137.

The estimated burnups of specimens in all three capsules have been determined as of the end of MTR Cycles 136, 138, and 142, respectively. Burnups were calculated from fission power generation, as determined by thermocouples adjacent to the specimens, and the heat-transfer characteristics of the capsules. The burnups of specimens operating at the highest and lowest temperature in each capsule are given in Table S-2.

Present plans call for the first capsule (BMI-31-3) to be discharged from the reactor at the end of MTR Cycle 139 (about June 1). It is anticipated that the capsule will be shipped to the General Atomic hot cells for postirradiation examination. A discharge date has not been selected for the remaining two capsules.

Thermal Conductivity of Beryllia

H. W. Deem and C. F. Lucks

An apparatus for measurement of thermal conductivity of beryllia up to $2000 \mathrm{~F}$ is being fabricated. Attention is being given to making the apparatus versatile so that the inner structure can be changed readily to accommodate specimens of differing geometries. 
TABLE S-1. TEMPERATURE AND ELECTRICAL-HEATER POWER CONSUMPTION FOR CAPSULES BMI-31-1, BMI-31-2, AND BMI-31-3 DURING MTR CYCLE 137

\begin{tabular}{|c|c|c|c|c|c|c|c|}
\hline \multirow[b]{2}{*}{ Capsule } & \multirow{2}{*}{$\begin{array}{c}\text { Electrical-Heater Power } \\
\text { Consumption, } w\end{array}$} & \multirow[b]{2}{*}{ No. 1} & \multirow[b]{2}{*}{ No. 2} & \multicolumn{4}{|c|}{ Thermocouple Reading (a), F } \\
\hline & & & & No. 3 & No. 4 & No. 5 & No. 6 \\
\hline BMI-31-1 & 750 & -- & -- & $1490^{\text {(b) }}$ & 1465 & 1290 & $\cdots$ \\
\hline BMI-31-2 & 2500 & 1470 & -- & 1460 (b) & -- & -- & 1485 \\
\hline BMI-31-3 & 3100 & 1455 & $1495^{(b)}$ & -- & 1485 & -- & 1450 \\
\hline
\end{tabular}

(a) Specimen-surface temperatures are calculated to be 25 to $30 \mathrm{~F}$ higher.

(b) Controlling thermocouple.

TABLE S-2. ESTIMATED BURNUP OF SPECIMENS CONTAINED IN CAPSULES BMI-31-1, BMI-31-2, AND BMI-31-3 AT INDICATED DATES

\begin{tabular}{|c|c|c|c|c|c|c|}
\hline \multirow[b]{3}{*}{ Capsule } & \multicolumn{6}{|c|}{ Estimated Specimen Burnup at Date Shown, a /o uranium } \\
\hline & \multicolumn{2}{|c|}{$\begin{array}{c}\text { End of } \\
\text { MTR Cycle } 136 \\
\text { (April 1, 1960) }\end{array}$} & \multicolumn{2}{|c|}{$\begin{array}{c}\text { End of } \\
\text { MTR Cycle 138 } \\
\text { (May 9, 1960) } \\
\end{array}$} & \multicolumn{2}{|c|}{$\begin{array}{c}\text { End of } \\
\text { MTR Cycle 142 } \\
\text { (August 1, 1960) }\end{array}$} \\
\hline & Maximum & Minimum & Maximum & Minimum & Maximum & Minimum \\
\hline BMI-31-1 & 21.5 & 15.5 & 25.0 & 18.2 & 32.5 & 23.5 \\
\hline BMI-31-2 & 14.5 & 11.5 & 16.7 & 13.2 & 21.5 & 17.0 \\
\hline BMI-31-3 & 14.0 & 9.5 & 16.2 & 11.3 & 21.0 & 14.5 \\
\hline
\end{tabular}


As soon as heaters are installed, the equipment will be ready for assembly and calibration. Scheduled calibration has been delayed to permit location and repair of unusually numerous vacuum leaks in the guard cooling assembly. A stainless steelArmco iron calibration standard has been machined and assembled and is ready for installation.

It is expected that as sembly and calibration will be completed within the first 2 weeks in May.

\section{Preparation and Coating of Uranium and Thorium Carbide Powders}

J. H. Oxley, R. B. Landrigan, A. C. Secrest, C. F. Powell, and J. M. Blocher, Jr.

An experimental program is under way to determine the feasibility of preparing uranium and thorium carbide powders and, subsequently, to coat these powders with carbon, niobium carbide, or zirconium carbide films by vapor-deposition techniques. Parallel efforts on both preparation and coating are being carried out.

An investigation of the kinetics of the deposition of carbon from acetylene in a fluidized bed was completed in April. The effects of bed temperature, bed surface area, and acetylene partial pressure on the rate of deposition were tentatively correlated by the expression:

$$
\mathrm{w}_{\mathrm{C}}=\frac{8.4 \times 10^{5}}{\mathrm{~T}_{\mathrm{B}}} \underset{\mathrm{C}_{2} \mathrm{H}_{2}}{\mathrm{p}} \mathrm{S}_{\mathrm{B}}^{0.92} \mathrm{e}^{-50,230 / \mathrm{RT}_{\mathrm{B}}}
$$

where

$\mathrm{W}_{\mathrm{C}}=$ rate of carbon deposition, 1.36 to $24.6 \mathrm{~g}$ per $\mathrm{hr}$

$\mathrm{T}_{\mathrm{B}}=$ deposition temperature, 1123 to $1366 \mathrm{~K}$

$P_{\mathrm{C}_{2} \mathrm{H}_{2}}=$ acetylene partial pressure, 77 to $249 \mathrm{~mm}$ of mercury

$\mathrm{S}_{\mathrm{B}}=$ surface area of bed, 3320 to $11,900 \mathrm{~cm}^{2}$.

The hydrogen contents of these pyrolytic carbon films have been measured. Assuming the hydrogen content of the fused alumina starting bed is negligible, the atomic carbon-to-hydrogen ratios of the pyrolytic carbon films were tentatively correlated by the expression:

$$
\log _{10} \mathrm{C} / \mathrm{H}=6.54-\frac{6.17 \times 10^{3}}{\mathrm{~T}},
$$

where

$$
\begin{aligned}
\mathrm{C} / \mathrm{H} & =\text { atomic carbon-hydrogen ratio, } 12 \text { to } 66 \\
\mathrm{~T} & =\text { deposition temperature, } 1120 \text { to } 1290 \mathrm{~K} .
\end{aligned}
$$

The porosities of these carbon films were determined by leaching the coated uranium-containing powders with hot $(95 \mathrm{C})$ concentrated (1:1) nitric acid for extended periods of time. The results of these tests are summarized in Table S-3. The coating program is now being directed toward a study of the deposition of niobium carbide films on uranium carbide. 
TABLE S-3. POROSITIES OF CARBON FILMS ON URANIUM-CONT AINING POWDERS DETERMINED BY LEACHING IN HOT CONCENTRATED NITRIC ACID

\begin{tabular}{|c|c|c|c|c|c|c|c|c|c|}
\hline \multirow[b]{2}{*}{$\begin{array}{c}\text { Core } \\
\text { Material } \\
\end{array}$} & \multirow[b]{2}{*}{$\begin{array}{l}\text { Film Thickness, } \\
\mu\end{array}$} & \multicolumn{3}{|c|}{ Coating Conditions } & \multicolumn{5}{|c|}{$\begin{array}{l}\text { Amount of Uranium Leached by Acid } \\
\text { During Indicated Interval, per cent }\end{array}$} \\
\hline & & Feed & $\begin{array}{c}\text { Partial Pressure, } \\
\text { atm }\end{array}$ & $\begin{array}{c}\text { Temperature, } \\
\mathrm{C} \\
\end{array}$ & $\begin{array}{c}0-1 \\
\mathrm{hr}\end{array}$ & $\begin{array}{c}1-6 \\
\mathrm{hr} \\
\end{array}$ & $\begin{array}{c}0-8 \\
\mathrm{hr} \\
\end{array}$ & $\begin{array}{c}\begin{array}{c}6-12 \\
\mathrm{hr}\end{array} \\
\end{array}$ & $\begin{array}{c}8-15 \\
\mathrm{hr}\end{array}$ \\
\hline $\mathrm{UO}_{2}$ & 1 & $\mathrm{CH}_{4}$ & 1 & 1015 & 88.8 & 4.47 & - & 0.07 & -- \\
\hline $\mathrm{UO}_{2}$ & 7 & $\mathrm{C}_{2} \mathrm{H}_{4}$ & $1 / 3$ & 1015 & 0.28 & 0.006 & -- & $<0.001$ & -- \\
\hline $\mathrm{UC}_{2}$ & 7 & $\mathrm{CH}_{4}$ & $1 / 3$ & 1125 & 15.5 & 10.5 & -- & 11.3 & -- \\
\hline $\mathrm{UC}_{2}$ & 17 & $\mathrm{C}_{2} \mathrm{H}_{2}$ & $1 / 3$ & 1020 & -- & -- & 0.004 & -- & $<0.001$ \\
\hline $\mathrm{UC}_{2}$ & 40 & $\mathrm{C}_{2} \mathrm{H}_{2}$ & $1 / 3$ & 1020 & -- & -- & 0.004 & -- & $<0.001$ \\
\hline
\end{tabular}

Additional studies were carried out during April to define a, range of conditions for deposition of uranium carbide from uranium tetraiodide and methane-hydrogen mixtures. The principal difficulty has been preferential deposition of carbon over the conditions investigated, resulting in a product containing relatively large excesses of carbon. The use of metallic reducing agents will be investigated in the near future as a means of avoiding this difficulty. 
DEVELOPMENTAL STUDIES FOR THE SM-1 AND SM-2 (ALCO)

\author{
S. J. Paprocki
}

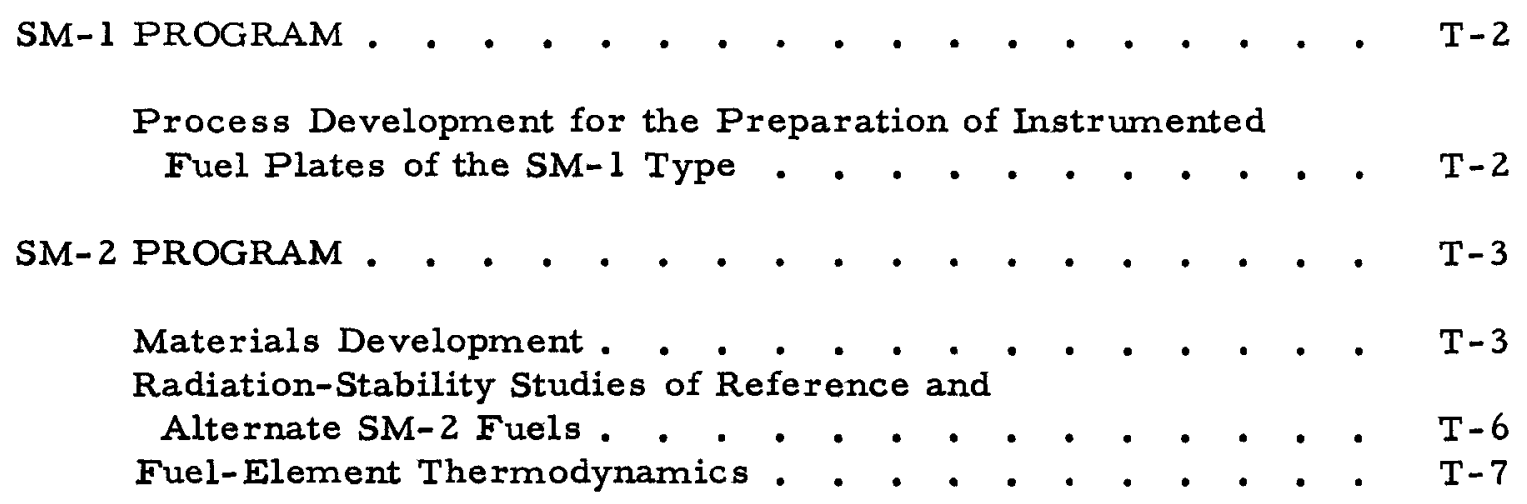

These studies are being conducted in assistance to Alco Products and are concerned with the development of an instrumented element for insertion in the SM-1 and development of fuel, absorber, and suppressor materials for the SM-2. 
Process Development for the Preparation of Instrumented Fuel Plates of the SM-1 Type

S. J. Paprocki, E. S. Hodge, C. B. Boyer, and E. G. Smith

Techniques are being developed for the preparation of instrumented fuel elements of the SM-1 type for in-pile test evaluations. The instrumentation of these fuel plates will permit measurement of core temperatures and flow rates. The blocked-channel method of instrumenting fuel plates will be employed. This method of instrumentation was developed at Bettis for similar geometry and functional considerations; however, a metallurgical development is required to adapt this method to SM-1 stainless steeltype fuel plates.

For the instrumented SM-1 type fuel plates, it will be necessary to substitute a low-cross-section material for the stainless steel in the relatively massive center-plate area. This center-plate area will consist of a Zircaloy-2 filler plate enclosed in a stainless steel picture-frame jacket. The center plate will in turn be covered on top and bottom with SM-1 fuel plates of one-half standard thickness. The bonded instrumented assembly will have an over-all thickness equivalent to two standard SM-1 fuel plates and one water channel. The Zircaloy-2 filler material in the center plate will contain the thermocouples. The final full-scale instrumented assembly is to be gaspressure bonded to obtain a sound metallurgical bond at the structural mating interfaces.

It is known that at the pressure-bonding temperatures normally used for stainless steel, a eutectic is formed between zirconium and the iron in stainless steel. It is desired to develop a suitable barrier material that will bond to both zirconium and stainless steel. Niobium has been chosen as a possible barrier material because it has a favorable cross section and bonds well with zirconium.

Studies to date have been concerned with the niobium-stainless steel bond. Metallographic examination of these bonds indicate that there is a rather brittle diffusion zone formed between the two when gas-pressure bonded at temperatures of 2000 to $2100 \mathrm{~F}$ at $10,000 \mathrm{psi}$ for $3 \mathrm{hr}$. Separations in the bond interface of sectioned specimens have been observed between the iron-niobium zone and the niobium foil. This brittle zone contained numerous cracks in many of the specimens. Differences in thermalexpansion properties of stainless steel and niobium may have caused the separation in the reaction zone during cooling or interface cracking may have resulted from the sectioning of the specimens.

Studies are being conducted using various techniques in an attempt to improve the stainless-to-niobium bond. These consist of using intermediate layers that form solid solutions with niobium that might form a less brittle interface with the stainless steel. These will include molybdenum, tantalum, and vanadium. The high cross sections of these materials should not be too undesirable, since only a very thin layer will be investigated. 


\section{Materials Development}

S. J. Paprocki, D. L. Keller, G. W. Cunningham, A. K. Foulds, and D. E. Lozier

Reference materials have been selected and refined techniques are being established for the fabrication of SM-2 fuel plates. Procedures are also being developed for the fabrication of absorber plates.

$\underline{\text { Fuel Materials }}$

The reference fuel element contains a core of approximately $26 \mathrm{w} / 0 \mathrm{UO}_{2}$ and $1.2 \mathrm{w} / 0 \mathrm{ZrB}_{2}$ dispersed in a Type 347 prealloyed stainless powder matrix $10.030 \mathrm{in}$. thick) and clad with 0.005-in.-thick Type 347 stainless steel.

The fabrication of a series of $60 \mathrm{SM}-2$ type fuel plates containing fully enriched $\mathrm{UO}_{2}$ has been completed. Of these plates, 38 were shipped to Alco for welding into elements. The welded elements will be irradiated in the SM-1.

Ten plates of reference and alternate fuel systems were selected from the plates retained at Battelle for chemical analyses and metallographic studies. Six specimens 1-1/4 in. in diameter were punched from each of eight plates. Three each were analyzed for boxon and uranium content. Two entire plates are being dissolved for boron analyses. Specimens were taken from three locations (the stem end, center, and suppressor-fuel core junction) in each of eight plates for metallography.

The results of chemical analyses on one enriched SM- 2 fuel plate have been obtained and are shown in Table $\mathrm{T}-1$. The analyses on $1-1 / 4-$ in.-diameter punchings ranged $0.166 \mathrm{w} / 0$ to $0.179 \mathrm{w} / 0$ for boron and $16.9 \mathrm{w} / 0$ to $17.5 \mathrm{w} / 0$ for uranium. Cladding thickness ranged from 4.5 to 5.5 mils.

TABLE T-1, CHEMICAL ANALYSIS ON SM-2 REFERENCE FUEL PLATE EAR-34

\begin{tabular}{ccccc}
\hline \hline Sample(a) & $\begin{array}{c}\text { Uranium(b), } \\
\text { w/o }\end{array}$ & Sample(a) & $\begin{array}{c}\text { Boron, } \\
\text { w/o }\end{array}$ & $\begin{array}{c}\text { Cladding } \\
\text { Thickness, } \\
\text { mils }\end{array}$ \\
\hline A & 16.9 & F & 0.179 & 5 to $5-1 / 2$ \\
B & 17.5 & G & 0.177 & 5 \\
C & 17.1 & H & 0.170 & 4 to $4-1 / 2$ \\
D & 17.2 & I & 0.166 & 4 to $4-1 / 2$ \\
E & 17.3 & J & 0.166 & $4-1 / 2$ to 5 \\
\hline
\end{tabular}

(a) Samples are 1-1/4-in. -diameter punchings taken on a diagonal down the length of the plate. The letters progress toward the suppressor end of the plate.

(b) Calculated on basis of uranium-238. 
A compilation of core dimensions taken from the radiographs of the $38 \mathrm{SM}-2$ type fuel plates sent to Alco is listed in Table T-2. The fade-out of the suppressor between the cladding and frame on the SM- 2 fuel plates varied considerably in length. Examination of 23 EAR plates showed a range of 0.05 to 0.16 in. with an average of 0.12 in. for the tail effects.

TABLE $\mathrm{T}-2$. COMPILATION OF CORE DIMENSIONS OF SM-2 TYPE FUEL PLATES SENT TO ALCO

\begin{tabular}{lcc}
\hline \multicolumn{1}{c}{ Dimension } & Average, in. & Range, in. \\
\hline Total core length & 22.70 & 22.10 to 23.25 \\
Nominal active core length & 21.88 & 21.37 to 22.27 \\
Nominal suppressor length & 0.570 & 0.520 to 0.600 \\
Core width - 3 in. from suppressor end & 2.679 & 2.655 to 2.699 \\
Core width - center & 2.674 & 2.658 to 2.700 \\
Core width - 3 in. from stem end & 2.673 & 2.659 to 2.695 \\
Core camber & 0.0185 & 0 to 0.044 \\
Minimum core-to-edge distance & 0.071 & 0.050 to 0.030 \\
\hline
\end{tabular}

In an effort to decrease the tail effect (gradual fade-out of suppressor into frame) to an even shorter length, procedures are being investigated for holding the cladding and the frame in contact prior to or during the first part of the hot-rolling operation. One set of plates was rolled using the following techniques: (1) rolling with a larger diameter rolling mill, (2) making lighter reductions on the first passes, and (3) spot welding the cover plate close to the suppressor. Table T-3 lists the results of these preliminary tests. The use of lighter reductions during the early passes looks most promising. However, this procedure cannot be considered for actual use until it is shown that (1) the core structure is not damaged, (2) the increased number of passes and preheat time do not increase boron loss, and (3) the tail effects are substantially shorter on a number of plates.

TABLE T -3. FEATHERING OF SUPPRESSOR END OF SM-2 FUEL PLATES

\begin{tabular}{|c|c|c|c|c|c|c|c|c|}
\hline \multirow[b]{2}{*}{ Plate } & \multirow{2}{*}{$\begin{array}{l}\text { Hot Roll(a) } \\
\text { Diameter, in. }\end{array}$} & \multicolumn{5}{|c|}{ Hot Reduction in Pass Shown, per cent } & \multirow{2}{*}{$\begin{array}{c}\text { Cold } \\
\text { Reduction, } \\
\text { per cent }\end{array}$} & \multirow{2}{*}{$\begin{array}{c}\text { Feathering at } \\
\text { Suppressor End, } \\
\text { in. }\end{array}$} \\
\hline & & 1 & 2 & 3 & 4 & Balance & & \\
\hline $\begin{array}{c}\text { Average of } 23 \\
\text { EAR plates }\end{array}$ & 8 & 30 & 30 & 20 & 20 & 20 & 18 & $0.12^{(b)}$ \\
\hline DAR-109 & 16 & 30 & 30 & 20 & 20 & 20 & 11 & 0.18 \\
\hline DAR-110 & 8 & 2 & 2 & 30 & 30 & 20 & 11 & 0.02 \\
\hline DAR-111 & 8 & 5 & 5 & 30 & 30 & 20 & 11 & 0.11 \\
\hline DAR-112(c) & 8 & 30 & 30 & 20 & 20 & 20 & 11 & 0.10 \\
\hline
\end{tabular}

(a) Plates hot rolled from a hydrogen muffle at $2200 \mathrm{~F}$, flipped, and reversed after each pass.

(b) Ranged 0.05 to 0.16 in.

(c) Six spot welds placed across pack $1 / 8$ in. from suppressor after cover plates welded on. 
Absorber and Suppressor Materials

The material chosen for the suppressor and absorber for the SM-2 reactor is $\mathrm{Eu}_{2} \mathrm{O}_{3}$ dispersed in a matrix of 71-18-11 elemental-powder blend of iron, chromium, and nickel. Commercial $\mathrm{Eu}_{2} \mathrm{O}_{3}$ powders prepared by several procedures have been investigated to determine their suitability as a dispersion. It has been observed that several of the powders produce a volatile phase upon sintering which reacts with the elemental chromium powder to form a nonmetallic phase. Dispersions containing the gas-emitting $\mathrm{Eu}_{2} \mathrm{O}_{3}$ have been found to swell upon sintering. A coating of oxide is formed around the chromium particles which is related in thickness to the quantity of gas emitted and which prevents the chromium particles from going into solution during rolling and subsequent heat treatment.

The $\mathrm{Eu}_{2} \mathrm{O}_{3}$ containing the greatest quantity of volatile phase has been found to be that produced by gas firing the material at $1800 \mathrm{C}$ in an air atmosphere. This material has shown approximately 5 and 7 per cent losses in weight, respectively, when heated for $2 \mathrm{hr}$ at $2300 \mathrm{~F}$ in a dry hydrogen atmosphere and $1 \mathrm{hr}$ at $3000 \mathrm{~F}$ in a vacuum of $5 \times 10^{-6} \mathrm{~mm}$ of mercury. A reaction was found to take place between the $\mathrm{Eu}_{2} \mathrm{O}_{3}$ and chromium in a compact containing this type of $\mathrm{Eu}_{2} \mathrm{O}_{3}$ dispersed in a chromium matrix and sintered twice at $2250 \mathrm{~F}$ for $1-1 / 4 \mathrm{hr}$ in a dry hydrogen atmosphere.

Dry-hydrogen-sintered dispersion specimens prepared from elemental-powder 71-18-11 iron-chromium-nickel and $\mathrm{Eu}_{2} \mathrm{O}_{3}$, which had been prepared by induction heating in a tungsten crucible at $1700 \mathrm{C}$ under a tank-hydrogen atmosphere, were found to contain less of an oxide coating around the chromium particles; however, the coating was still too severe to permit the chromium to go into solution.

Another batch of $\mathrm{Eu}_{2} \mathrm{O}_{3}$ was obtained which had a minimum of volatile phase present when sintered at $2250 \mathrm{~F}$ in hydrogen in a dispersion compact. This material was produced by using dry hydrogen in the induction furnace. A dispersion containing $16 \mathrm{w} / \mathrm{o}$ of this $\mathrm{Eu}_{2} \mathrm{O}_{3}$ in a matrix of 71-18-11 iron-chromium-nickel elemental powders was mixed in a V-type blender, green pressed at $10 \mathrm{tsi}$, sintered for $1-1 / 4 \mathrm{hr}$ at $2250 \mathrm{~F}$ in a dry hydrogen atmosphere, coined at $31 \mathrm{tsi}$, resintered for $1-1 / 4 \mathrm{hr}$ at $2250 \mathrm{~F}$ in a dry hydrogen atmosphere, and recoined at $31 \mathrm{tsi}$. This specimen shrank 6 per cent during the first sinter, 2 per cent during the second sinter, and contained only a trace of oxide around the chromium particles after sintering. This specimen was sectioned in half and rolled to a 7-1/2-10-1 reduction in thickness at $2200 \mathrm{~F}$ in a Type 347 stainless steel frame. One specimen was annealed at $2050 \mathrm{~F}$ for $1 \mathrm{hr}$ and was found to contain a small quantity of undissolved chromium; however, the chromium was dissolved in the other specimen, which was annealed at $2300 \mathrm{~F}$ for $1 \mathrm{hr}$.

Additional specimens are being prepared and sintering procedures studied in an effort to eliminate the remaining oxide and improve the structure of the rolled dispersion. 
Radiation-Stability Studies of Reference and Alternate SM-2 Fuels

W. E. Murr, J. F. Lagedrost, J. H. Stang, and J. E. Gates

A study of the radiation stability of reference and potential fuels for the SM- 2 reactor is in progress. Fuels being irradiated include nominal $24 \mathrm{w} / 0$ to $40 \mathrm{w} / \mathrm{o}$ fully enriched $\mathrm{UO}_{2}$ dispersed in Type 347 stainless steel and clad with Type 347 stainless steel. The platelet-type fuel specimens also contain burnable poisons in the form of $\mathrm{B}_{4} \mathrm{C}, \mathrm{ZrB} 2$, and $\mathrm{NbB}_{2}$. Ten capsules containing six, seven, or eight specimens are included in the program. The specimens will be irradiated at surface temperatures ranging from 600 to $700 \mathrm{~F}$ to burnups of 40 to 70 per cent of the uranium-235 in the MTR and ETR.

The irradiation in the MTR core of three noninstrumented capsules, BMI-32-1, BMI-32-2, and BMI-32-3, has been completed. The irradiation in the ETR of an instrumented (thermocouples and heaters) capsule, BMI-32-4, has also been completed. The postirradiation examination of the specimens from the se capsules has been initiated. Two additional instrumented capsules, BMI-32- 6 and BMI-32-8, are presently being irradiated in the ETR. Capsule BMI-32-5 was inserted into the ETR but had to be withdrawn due to a cracked lead tube. Of the remaining three capsules, two are being assembled and one is at the ETR awaiting insertion.

\section{Encapsulation and Irradiation}

Capsule-irradiation studies designed to assist in establishing specifications for the SM-2 core are in progress. A ten-capsule program in which clad plate-type specimens (nominally $26 \mathrm{w} / \mathrm{O} \mathrm{UO}_{2}$-stainless steel dispersions including, in some cases, small amounts of boron compounds) are being exposed under conditions designed to maintain 600 to $700 \mathrm{~F}$ surface temperatures, while achieving uranium-235 burnups of the order of $70 \mathrm{a} / 0$, is in progress at the MTR and the ETR.

The MTR core irradiations of three noninstrumented capsules, BMI-32-1, BMI-32-2, and BMI-32-3, have been completed; postirradiation examinations are in progress at the Battelle Hot-Cell Facility. The first instrumented (heaters and thermocouples) capsule, BMI-32-4, was discharged from the ETR on April 4, following an eight-cycle irradiation. It also is undergoing hot-cell examination.

Two additional instrumented capsules, BMI-32-6 and BMI-32-8, were inserted in Positions $\mathrm{O}-5$ and L-4, respectively, in the ETR beryllium reflector for Cycle 28 , which started on April 29. Early performance data indicate that design temperatures probably will be achievable at all of the specimens in both capsules during these irradiations. At a 150-megawatt reactor power and with no electric heat added, thermocouple temperatures of approximately $350 \mathrm{~F}$ were observed. The addition of 3 to $4 \mathrm{kw}$ of electric heating resulted in thermocouple temperatures just over $400 \mathrm{~F}$, and calculated specimensurface temperatures of $650 \mathrm{~F}$. It may be speculated that full-power reactor operation (175 megawatts) will almost achieve design temperatures without electric heating during the initial phases of the irradiation. 
Of the four remaining instrumented capsules of the series, BMI-32-5 and BMI-32-9 are at the ETR, and BMI-32-7 and BMI-32-10 are being assembled. Capsule BMI-32-5 was scheduled for insertion for Cycle 28, but had to be withdrawn when a lead-tube fracture developed during installation. The capsule will be returned to Battelle for repair. Capsule BMI-32-9 probably will be inserted for Cycle 29. Assembly of the two final capsules should be completed during May.

Evaluation of Irradiated Specimens

Four capsules, BMI-32-1, BMI-32-2, BMI-32-3, and BMI-32-4, were received at the Hot-Cell Facility during April. The specimens will be recovered and the postirradiation examination initiated during May. Specimens irradiated in these capsules are listed in Table T-4 along with estimated burnups.

The postirradiation examination of the specimens will include determination of the amount of fission gases released from the specimens, measurement of changes in dimensions and density, visual examinations, radiochemical or isotopic burnup analyses, metallographic examination of the core and cladding microstructures, and heat treatments at $750 \mathrm{~F}$ to determine if any additional swelling will occur. It is expected that these examinations will be completed by the end of $\mathrm{J}$ une.

\section{Fuel-Element Thermodynamics}

\section{J. J. Ward, C. A. Alexander, A. W. Lemmon, Jr. ,} and R. B. Filbert, Jr.

Effort was continued during April on the program to study the thermodynamics of postulated reactions between fuel-element materials and between fuel-element materials and surrounding atmospheres. Of primary interest are those reactions which could lead to boron loss during fabrication of the current SM-2 element. Future interest will be in alternate materials and their possible reactions.

During this month - Ifort was continued on: (1) the thermodynamic evaluation of postulated chemical reactions which might lead to boron loss, (2) the accumulation of basic thermodynamic data from the literature, by calculation, and by estimation, to permit the evaluation of the postulated reactions, and (3) the experimental confirmation of basic thermodynamic data, primarily that for $\mathrm{ZrB}_{2}$.

As described last month in BMI-1430, approximately 300 chemical reactions which might lead to reaction of $\mathrm{ZrB}_{2}$ and possible boron loss during fuel-element fabrication have been formulated. The thermodynamic evaluation of these reactions is proceeding as rapidly as the basic data can be accumulated. Thus far, it has been confirmed that both water vapor and oxygen are reactive with $\mathrm{ZrB}_{2}$.

The reaction with gaseous oxygen to form $\mathrm{ZrO}_{2}$ and $\mathrm{BO}(\mathrm{g})$ shows a free energy of reaction of $-203 \mathrm{kcal}$ per $\mathrm{g}$ mole of $\mathrm{ZrB}_{2}$. Other reaction products such as $\mathrm{B}_{2} \mathrm{O}_{3}$ are also quite possible. 
TABLE T-4. SUMMARY OF SPECIMENS CONTAINED IN CAPSULES BMI-32-1, BMI-32-2, BMI-32-3, AND BMI-32-4

\begin{tabular}{|c|c|c|c|c|c|c|}
\hline \multirow[b]{3}{*}{ Capsule(a) $^{(a)}$} & \multirow[b]{3}{*}{ Specimen(b) } & \multirow{3}{*}{$\begin{array}{c}\text { Specimen Composition } \\
\text { (Balance Type } 347 \text { Stainless Steel), } \\
\text { w/o }\end{array}$} & \multicolumn{4}{|c|}{ Estimated Burnup $(c), a / o$} \\
\hline & & & \multicolumn{2}{|c|}{ Minimum } & \multicolumn{2}{|c|}{ Maximum } \\
\hline & & & Fission & Total & Fission & Total \\
\hline \multirow[t]{7}{*}{ BMI $-32-1$} & $2-7 \mathrm{~V}$ & $26 \mathrm{UO}_{2} ; 0.095 \mathrm{ZrB}_{2}$ & 49 & 59 & 61 & 73 \\
\hline & $2-2-1$ & $26.1 \mathrm{UO}_{2} ; 0.192 \mathrm{~B}_{4} \mathrm{C}$ & & & & \\
\hline & $2-5 V$ & $26.0 \mathrm{UO}_{2} ; 0.199 \mathrm{ZrB}_{2}$ & & & & \\
\hline & $9-2$ & $26.0 \mathrm{UO}_{2} ; 0.209 \mathrm{NbB}_{2}$ & & & & \\
\hline & $3-5$ & $26.0 \mathrm{UO}_{2} ;$ no poison & & & & \\
\hline & $4-5$ & $26.0 \mathrm{UO}_{2} ;$ no poison & & & & \\
\hline & $8-5 V(d)$ & $26.0 \mathrm{UO}_{2} ; 0.240 \mathrm{ZrB}_{2}$ & & & & \\
\hline \multirow[t]{8}{*}{ BMI $-32-2$} & $14-2-4$ & $25.9 \mathrm{UO}_{2}$; boron $-10(\mathrm{e})$ & 48 & 57 & 63 & 75 \\
\hline & $2-2-2$ & $26.1 \mathrm{UO}_{2} ; 0.192 \mathrm{~B}_{4} \mathrm{C}$ & & & & \\
\hline & $3-3$ & $26.0 \mathrm{UO}_{2} ;$ no poison & & & & \\
\hline & $9-3$ & $26.0 \mathrm{UO}_{2} ; 0.209 \mathrm{NbB}_{2}$ & & & & \\
\hline & $13-8$ & $26.0 \mathrm{UO}_{2} ; 0.202 \mathrm{NbB}_{2}$ & & & & \\
\hline & $5-5 V$ & $26.0 \mathrm{UO}_{2} ; 0.199 \mathrm{ZrB}_{2}$ & & & & \\
\hline & $5-1$ & $24.2 \mathrm{UO}_{2} ; 0.021 \mathrm{~B}_{4} \mathrm{C}$ & & & & \\
\hline & $10-4$ & $26.0 \mathrm{UO}_{2} ; 0.192 \mathrm{ZrB}_{2}$ & & & & \\
\hline \multirow[t]{7}{*}{ BMI $-32-3$} & $13-3$ & $26.0 \mathrm{UO}_{2} ; 0.204 \mathrm{NbB}_{2}$ & 36 & 42 & 53 & 62 \\
\hline & $3-7 V$ & $26.0 \mathrm{UO}_{2} ; 0.095 \mathrm{ZrB}_{2}$ & & & & \\
\hline & $14-2-3$ & $25.9 \mathrm{UO}_{2}$; boron $-10(\mathrm{e})$ & & & & \\
\hline & $1-1$ & $24.2 \mathrm{UO}_{2} ; 0.021 \mathrm{~B}_{4} \mathrm{C}$ & & & & \\
\hline & $4-4$ & $26.0 \mathrm{UO}_{2} ;$ no poison & & & & \\
\hline & $10-2$ & $26.0 \mathrm{UO}_{2} ; 0.192 \mathrm{ZrB}_{2}$ & & & & \\
\hline & $8-1 V^{(d)}$ & $26.0 \mathrm{UO}_{2} ; 0.240 \mathrm{ZrB}_{2}$ & & & & \\
\hline \multirow[t]{6}{*}{ BMI $-32-4$} & $1-12 \mathrm{~V}$ & $26.0 \mathrm{UO}_{2} ; 0.209 \mathrm{ZrB}_{2}$ & 18 & 21 & 34 & 41 \\
\hline & $2-3$ & $26.0 \mathrm{UO}_{2}$; no poison & & & & \\
\hline & $3-4$ & $26.0 \mathrm{UO}_{2} ;$ no poison & & & & \\
\hline & $2-6 V$ & $26.0 \mathrm{UO}_{2} ; 0.213 \mathrm{ZrB}_{2}$ & & & & \\
\hline & $4-7 A$ & $26.0 \mathrm{UO}_{2} ; 0.093 \mathrm{ZrB}_{2}$ & & & & \\
\hline & $4-11$ & $26.0 \mathrm{UO}_{2} ; 0.207 \mathrm{NbB}_{2}$ & & & & \\
\hline
\end{tabular}

(a) Capsules BMI-32-1, BMI-32-2, and BMI-32-3 were irradiated in MTR. Capsule BMI-32-4 was irradiated in ETR.

(b) Specimens are listed, top to bottom, as they were loaded in capsule.

(c) Burnups were estimated from reactor-quoted flux.

(d) Contains $\mathrm{Eu}_{2} \mathrm{O}_{3}$ suppressor.

(e) Boron-10 was alloyed in stainless steel frame. Boron content was $0.023 \mathrm{w} / \mathrm{o}$. 
GAS-CC

Fabrication of $\mathrm{BeO}-\mathrm{UO}_{2}$ Study of Processing Var of $\mathrm{BeO}-\mathrm{UO}_{2}$ Ceramics Effects of Irradiation Alloy Modification of $\mathrm{Ha}$ GCRE Critical-Assembl BRR Loop Program . ETR Loop Program.

Studies for Aerojet-Gent directed toward the developme section.

Fabrication of the 42001 able pellets, 94 per cent, wer

Initial results on the sin $\mathrm{BeO}$, high densities were obta ments on the resintering of sc per cent scrap material recyc per cent of theoretical after si

Eight specimens (four ez have been examined visually a: $1550 \mathrm{~F}$ at burnups of from 9.5 good condition.

The ML-1-1B achieved $c$ worth of the safety-shutdown b made on a second core (49 eler power distributions.

The sixth specimen irrac at the Battelle Research React in May. Irradiation of the firs Reactor has been delayed by $m$
The reaction of $\mathrm{ZrB}_{2}$ with $\mathrm{H}_{2} \mathrm{O}$ to give products of $\mathrm{ZrO}_{2}$, $\mathrm{BO}$, and hydrogen shows a free energy of reaction of $-41.6 \mathrm{kcal}$ per $\mathrm{g}$ mole of $\mathrm{ZrB}_{2}$, indicating very good likelihood of reaction occurring.

It has also been determined that the disproportionation of $\mathrm{ZrB}_{2}$ to form zirconium and volatile boron vapor is extremely unlikely. The free energy for this reaction (at $2100 \mathrm{~F}$ ) is $+248.6 \mathrm{kcal}$ per $\mathrm{g}$ mole of $\mathrm{ZrB}_{2}$.

One somewhat unexpected result has been obtained. The reaction of $\mathrm{ZrB}_{2}$ with nitrogen gas to form $\mathrm{ZrN}$ plus $\mathrm{BN}$ has been shown to have a free energy of reaction (at $2100 \mathrm{~F}$ ) of $-11.3 \mathrm{kcal}$ per $\mathrm{g}$ mole of $\mathrm{ZrB}_{2}$. This indicates the possibility of nitrogen gas being a troublemaker during high-temperature fabrication.

Additional basic data have been developed from the literature and by estimation and calculation. In addition to the equations reported last month for $\mathrm{ZrB}_{2}$, the following equations have been developed during the current period:

$$
\begin{gathered}
\left.\mathrm{H}_{\mathrm{T}}-\mathrm{H}_{298} \text { (cal per } \mathrm{g} \text { mole }\right)=15.93 \mathrm{~T}+0.89 \times 10^{-3} \mathrm{~T}^{2}-5296(1073 \text { to } 3263 \mathrm{~K}) \\
\Delta \mathrm{F}_{\mathrm{T}}^{\circ} \text { (cal per } \mathrm{g} \text { mole) }=-72,405+5.85 \mathrm{~T} \log _{10} \mathrm{~T}-0.18 \times 10^{-3} \mathrm{~T}^{2}-15.26 \mathrm{~T} \\
(1073 \text { to } 1800 \mathrm{~K}) \\
\Delta \mathrm{H}_{\mathrm{T}}^{\circ}(\text { cal per } \mathrm{g} \text { mole })=-72,405-2.54 \mathrm{~T}+0.18 \times 10^{-3} \mathrm{~T}^{2} \\
\text { (1100 to } 1800 \mathrm{~K})
\end{gathered}
$$

In all these equations $T$ is expressed in deg $K$.

Standard values for free energy of formation have been developed for many of the components in the reactions of interest. These are shown in Table T-5. Current effort is in determining similar values for $\mathrm{HBO}_{2}(\mathrm{~g}), \mathrm{H}_{2} \mathrm{BO}_{3}(\mathrm{~g}), \mathrm{B}_{2} \mathrm{H}_{6}$ and other boranes, FeB, $\mathrm{CrB}, \mathrm{NiB}$, and $\mathrm{NbB}_{2}$.

TABLE T -5 . STANDARD FREE ENERGIES OF FORMATION AT $2100 \mathrm{~F}$

\begin{tabular}{lc}
\hline \multicolumn{1}{c}{ Compound } & $\Delta \mathrm{F}^{*}$, cal per g mole \\
\hline $\mathrm{ZrB}_{2}(\mathrm{c})$ & $-68,241$ \\
$\mathrm{H}_{2} \mathrm{Og}^{\mathrm{g}}$ & $-40,336$ \\
$\mathrm{ZrO}_{2}(\mathrm{c})$ & $-197,288$ \\
$\mathrm{~B}_{2} \mathrm{O}_{3}(1)(\mathrm{mp} 841 \mathrm{~F})$ & $-223,600$ \\
$\mathrm{BO}(\mathrm{g})$ & $-36,940$ \\
$\mathrm{COg})$ & $-56,763$ \\
$\mathrm{ZrN}(\mathrm{c})$ & $-55,063$ \\
$\mathrm{ZrC}(\mathrm{c})$ & $-40,972$ \\
$\mathrm{BN}(\mathrm{c})$ & $-12,207$ \\
$\mathrm{~B}(\mathrm{~g})$ & $+90,179$ \\
\hline \hline
\end{tabular}

Since an accurate value for the free energy of formation of $\mathrm{ZrB}_{2}$ is necessary for evaluation of the possible reactions into which $\mathrm{ZrB}_{2}$ might enter, an experimental program is under way in an attempt to eliminate the present uncertainty in the value of the free energy of formation of $\mathrm{ZrB}_{2}$. 
Experiments were made $\Delta \mathbf{F}=-\mathrm{nfE}$. Three different el, and aqueous $\mathrm{Zr}\left(\mathrm{NO}_{3}\right)_{4}$. In none allow determination of $\Delta \mathbf{F}$. In for operation of the cell. The of the zirconium ion in solutior. cal per $\mathrm{g}$ mole at about $700 \mathrm{C}$ v possible to reproduce this valu. this electrolyte: first the elect preferential vaporization of $\mathrm{Zr}$ less dissociated in solution tha: not enough $\mathrm{Zr}^{+4}$ ions available. of the current is carried by the exists in the sodium zirconium

As an alternate method th. (where the excess carbon is uti run. The preliminary value of $-63 \pm 5$ kcal per $\mathrm{g}$ mole. This The heat of formation which is been found to be $-76.4 \pm 1.5$ for made at the site. While their $n$ with the values being used in th experimental value for the entr some importance to determine may be obtained. Experimenta: entropy of formation of $\mathrm{ZrB}_{2}$.
$\mathrm{U}-2$

\section{Fabrication of $\mathrm{BeO}-\mathrm{UO}_{2}$ Fuel Pellets}

H. D. Sheets and A. K. Smalley

The objective of this program is to prepare $\mathrm{BeO}-25$ volume per cent $\mathrm{UO}_{2}$ pellets for irradiation testing.

Fabrication of the required 4200 hollow pellets $0.200 \pm 0.031 \mathrm{in}$. high with an $O D$ of $0.1745 \pm 0.0015 \mathrm{in}$. and an ID of $0.055 \pm 0.005 \mathrm{in}$. was completed during April. The pellets were shipped to AGN. About 94 per cent of the pellets sintered were acceptable. Most of those rejected were chipped. Others were out of tole rance or showed internal flaws in radiographic examination. The bulk density of representative pellets ranged from 5.14 to $5.26 \mathrm{~g}$ per $\mathrm{cm}^{3}$ ( 97.1 to 99.4 per cent of theoretical).

Chemical analyses for $\mathrm{UO}_{2}$ content and microstructural examinations of representative pellets are in progress.

\section{Study of Processing Variables in the Fabrication of $\mathrm{BeO}-\mathrm{UO}_{2}$ Ceramics}

\section{H. D. Sheets and A. K. Smalley}

This program is directed toward the optimization of techniques for fabricating $\mathrm{BeO}-\mathrm{UO}_{2}$ fuel-elements pellets. Initial experiments are being performed using $\mathrm{Brush}$ $\mathrm{LOH}$-grade $\mathrm{BeO}$ and ceramic-grade $\mathrm{UO}_{2}$ powders from various suppliers. Three steps in the process are being investigated.

The initial effort was directed toward minimizing the time required to prepare a batch for pressing. It appears that dry blending the batch prior to wet mixing may be unnecessary. Batches prepared by wet mixing alone pressed satisfactorily, and yielded pellets having the desired high sintered bulk density and dimensional uniformity Chemical analyses of representative pellets for $\mathrm{UO}_{2}$ content are planned. Future work on this phase of the program will include efforts to reduce the time required for drying the batch prior to pressing. This may be accomplished by reducing the amount of tempering water used or by using higher drying temperatures.

A second variable in the process which is being investigated is the effect of sintering conditions on the uniformity of the sintered diameter and on the sintered density. Studies will be directed toward minimizing the time and maximum temperature required for sintering. In the process used in a recent pilot-scale preparation of $\mathrm{BeO}-\mathrm{UO}_{2}$ pellets, the specimens were placed on a molybdenum boat in a hydrogen-atmosphere furnace. The furnace temperature was increased to about $1200 \mathrm{~F}$ in about $2-1 / 2 \mathrm{hr}$ and held at about $1200 \mathrm{~F}$ for $2 \mathrm{hr}$ to permit binder removal. Temperature then was increased to about $2800 \mathrm{~F}$ in about $2-1 / 2 \mathrm{hr}$, and held at $2800 \mathrm{~F}$ for $2 \mathrm{hr}$.

The effects of time and temperature of sintering for pellets made from Brush $\mathrm{LOH} \mathrm{BeO}$ and an experimental lot of minus 325-mesh $\mathrm{UO}_{2}$ were investigated. The experimental conditions and test results are shown in Table U-1. 
TABLE U-1. EFFECT OF SINTERING CONDITIONS ON BULK DENSITY AND DIAMETRAL SHRINKAGE OF BeO-UO ${ }_{2}$ SPECIMENS(a) $^{(a)}$

\begin{tabular}{|c|c|c|c|c|c|}
\hline \multirow[b]{2}{*}{ Batch } & \multirow{2}{*}{$\begin{array}{c}\text { Sintering } \\
\text { Temperature, } \\
\text { F } \\
\end{array}$} & \multirow{2}{*}{$\begin{array}{c}\text { Time at } \\
\text { Temperature, } \\
\text { hr }\end{array}$} & \multicolumn{2}{|c|}{ Sintered Density(b) } & \multirow{2}{*}{$\begin{array}{c}\text { Diametral } \\
\text { Shrinkage( }{ }^{(c)}, \\
\text { per cent }\end{array}$} \\
\hline & & & $\mathrm{G}$ per $\mathrm{Cm}^{3}$ & $\begin{array}{l}\text { Per Cent of } \\
\text { Theoretlcal }\end{array}$ & \\
\hline $2-1$ & 2800 & 2 & 5.18 & 98.0 & 20.7 \\
\hline $2-2$ & 2800 & 1 & 5.16 & 97.4 & 20.7 \\
\hline $2-4$ & 2800 & $1 / 6$ & 5.12 & 97.0 & 20.7 \\
\hline $2-5$ & 2600 & 1 & 4.87 & 92.5 & 19.0 \\
\hline $2-6$ & 2400 & 1 & 3.86 & 73.0 & 12.0 \\
\hline $12-A^{(d)}$ & 2800 & 2 & 4. 16 & 78.6 & 14.1 \\
\hline $12-B(d, e)$ & 2800 & 2 & 4.62 & 87.4 & 14.1 \\
\hline $12-c^{(d)}$ & 3000 & 2 & 4.67 & 88.3 & 16.8 \\
\hline $12-D^{(d, e)}$ & 3000 & 2 & 4.96 & 93.8 & 16.3 \\
\hline
\end{tabular}

(a) Except when otherwise indicated, $60 \mathrm{w} / \mathrm{o} \mathrm{UO} \mathrm{O}_{2}$ and $40 \mathrm{w} / \mathrm{o} \mathrm{BeO}$ powders were mixed with $4 \mathrm{w} / \mathrm{o}$ Nopeo $\mathrm{CD}-108$ binder and pressed at 20,000 psi.

(b) Average of two specimens, measured by xylene immersion. Theoretical density of $60 \mathrm{w} / \mathrm{O} \mathrm{UO} \mathrm{O}_{2}-40 \mathrm{w} / \mathrm{o}$ BeO was taken as $5.29 \mathrm{~g} \mathrm{per} \mathrm{cm}^{3}$

(c) Average of eıght specumens.

(d) Made using BeO supplied by AGN.

(e) Pressed at 40,000 psi. 
The se data indicate that a maximum sintering temperature in excess of $2600 \vec{r}$ is probably desirable. Also, as little as $10 \mathrm{~min}$ at $2800 \mathrm{~F}$ was sufficient to produce suitable bulk densities in the sintered pellets. Further experiments will be made to more precisely define the minimum sintering time and temperature requirements. Metallographic examinations will be made to determine the effects of sintering conditions on the microstructure of the sintered pellets.

Results of preliminary experiments on utilizing sintered scrap were promising. A number of $60 \mathrm{w} / 0 \mathrm{UO}_{2}-40 \mathrm{w} / \mathrm{o} \mathrm{BeO}$ pellets were disintegrated by oxidizing them in air at $1000 \mathrm{~F}$ for $2 \mathrm{hr}$. The oxidized materials easily passed through a 100 -mesh sieve. Ten parts of this material was mixed with 90 parts of virgin material, the batch was pressed at 20,000 or $40,000 \mathrm{psi}$, and then sintered at $2800 \mathrm{~F}$ for $2 \mathrm{hr}$. The specimens sintered to greater than 95 per cent of theoretical density. Microscopic examination and oxygen/uranium-ratio measurements are planned. Additional experiments to determine the effects of various scrap contents on sinterability, diametral shrinkage and uniformity, and microstructural characteristics are planned.

\section{Effects of Irradiation}

J. H. Saling, D. G. Freas, J. E. Gates, and R. F. Dickerson

A study of the radiation stability of various potential GCRE fuel materials is in progress. Materials presently being evaluated include dispersions of $\mathrm{UO}_{2}$ in $\mathrm{BeO}$ and in Type 318 stainless steel. The irradiation of one capsule, GCRE-BRR-2, containing $\mathrm{BeO}$ pellets fueled with $59 \mathrm{w} / 0$ fully enriched $\mathrm{UO}_{2}$ inside Hastelloy $\mathrm{X}$ tubes, and two capsules, BMI-33-1 and BMI-33-2, containing dispersions of both spherical and hydrothermal $\mathrm{UO}_{2}$ in Type 318 stainless steel clad with Type 318 stainless steel, have been completed.

Capsule GCRE-BRR-2 was equipped with thermocouples and electrical heaters and contained six specimens. The specimens were composed of four pellets of $\mathrm{BeO}-59$ $\mathrm{w} / \mathrm{o} \mathrm{UO}_{2}$ contained in a sealed tube of Hastelloy $\mathrm{X}$. The irradiation was conducted in the BRR for a total of four reactor cycles, giving an estimated 1.8 a/o burnup by fission of the uranium-235. Specimen-surface temperatures were about $1725 \mathrm{~F}$. As described in previous progress reports, the specimens were in good condition and exhibited only slight dimensional changes. Metallographic examinations indicated that no changes had occurred in the microstructure of the $\mathrm{BeO}$, the $\mathrm{UO}_{2}$, or the Hastelloy cladding. Burnup and fission-gas analyses are still in progress.

Capsules BMI-33-1 and BMI-33-2 were equipped with thermocouples, and each contained four plate-type specimens of $30 \mathrm{w} / \mathrm{o}$ fully enriched $\mathrm{UO}_{2}$ dispersed in and clad with Type 318 stainless steel. Two of the specimens in each capsule were fabricated from spherical $\mathrm{UO}_{2}$ and two from hydrothermal $\mathrm{UO}_{2}$ in order to permit a comparison of the radiation stability of the two types of $\mathrm{UO}_{2}$. Center-line temperatures ranged from 1100 to $1300 \mathrm{~F}$ for specimens in Capsule BMI-33-1 and 1280 to $1550 \mathrm{~F}$ for specimens in Capsule BMI-33-2. The fission burnup of uranium-235 was calculated to range from 11 to $15 \mathrm{a} / 0$ for specimens in Capsule BMI-33-1 and 9.5 to 11.5 a/o for specimens in Capsule BMI-33-2. All specimens were irradiated in contact with NaK. 
The postirradiation examination of the specimens irradiated in Capsules BMI-33-1 and BMI-33-2 has been partially completed. Each capsule was sampled for fission-gas content and then opened to permit recovery of the specimens. A detailed visual examination with a stereomacroscope showed that all of the specimens from both capsules were in good condition. A maximum density decrease of only about 0.85 per cent was detected in the specimens. Average increases in thickness ranged from 0.65 per cent to 2.6 per cent, with a maximum local swelling of about 8.4 per cent in one specimen. Sections were cut from a spherical and a hydrothermal $\mathrm{UO}_{2}$ specimen from each capsule. These sections will be used for burnup determinations and metallographic examinations. The metallographic examination will include a comparison study of the $\mathrm{UO}_{2}$ dispersion sizes, before and after irradiation. This study will involve a statistical analysis of the cross-sectional areas of the polished $\mathrm{UO}_{2}$ particles as measured with a planimeter. ing May.

The burnup analyses and metallographic examinations are scheduled to begin dur-

\section{Alloy Modification of Hastelloy X}

J. A. DeMastry, A. A. Bauer, and R. F. Dickerson

The loss in ductility (from 40 per cent total elongation to 12 per cent total elongation) which Hastelloy $X$ exhibits after a 5000-hr exposure to a nitrogen-l/2 volume per cent oxygen atmosphere at $1750 \mathrm{~F}$ may lead to cladding failures if a longer exposure results in an additional lowering of ductility. Either grain growth or carbide precipitation could be responsible for the observed lowering of tensile ductility. Grain growth can be remedied by the addition of a grain refiner such as yttrium. The embrittling effect of carbides in the grain boundaries may be counteracted by niobium or yttrium additions which may produce a more optimum phase distribution or act as a more ductile matrix to contain the carbides which might form. The program described herein has been undertaken in an attempt to improve the oxidation resistance and resistance of the base alloy to embrittlement during oxidation at elevated temperatures by alloy modification of the base Hastelloy $\mathrm{X}$ material. The alloys prepared are being evaluated prior to exposure to the oxidizing atmosphere and at various degrees of exposure. The oxidation tests are being conducted by Aerojet General and specimens for the tests are being supplied by BMI.

The alloy being studied is a nickel-21 w/o chromium $-20 \mathrm{w} / 0$ iron- $10 \mathrm{w} / 0$ molybdenum-0.7 w/o tung sten $-1.0 \mathrm{w} / 0$ manganese $-1.0 \mathrm{w} / 0$ silicon $-0.1 \mathrm{w} / 0$ carbon alloy. To the above base both yttrium and niobium are being added. It is hoped that these additions will improve the oxidation resistance of the base alloy while improving its ductility. The effect of minor variations in the base-alloy composition is also being studied. Chromium and nickel contents are being varied at the expense of the iron content, and the carbon content is also being varied.

One-kilogram ingots have been induction melted in alumina crucibles and poured at $2900 \mathrm{~F}$ into Zirconite molds. The ingots were forged to $3 / 8$-in. slabs at $2200 \mathrm{~F}$ and then rolled to $0.060-i n$. sheet at $2200 \mathrm{~F}$. All alloys except one containing $1.5 \mathrm{w} / \mathrm{o}$ yttrium and 25 w/o chromium instead of 21 w/o were successfully fabricated. A duplicate ingot of the latter alloy, which fractured during forging, has been prepared. This 
duplicate ingot has been successfully forged and rolled to 0.060-in. sheet. During forging the ingot was permitted to cool more than $100 \mathrm{~F}$ before reheating. This alloy appears to have a very narrow temperature range in which fabrication is successful.

Sheet tensile specimens have been prepared from the above alloys; and tensile properties will be determined at $75,1000,1750$, and $1850 \mathrm{~F}$.

Chemical analyses of the alloys have shown that the yttrium contents are about 50 per cent higher than planned. This is the result of overcharging of yttrium in anticipation of larger losses during melting than were realized. Analysis of one alloy with an intended nominal content of $0.5 \mathrm{w} / 0$ yttrium showed that all of the yttrium had been lost. This alloy has been recast and fabricated, and a chemical analysis of the replacement alloy is being made.

Samples for metallographic examination of the as-cast and wrought material have been obtained.

\section{GCRE Critical-Assembly Experiments}

J. W. Ray, R. G. Matthews, W. S. Hogan,

D. A. Dingee, and J. W. Chastain

Fuel for the ML-1-1B critical assembly was received, and experiments were started this month.

The initial approach to critical, using the standard critical-assembly-type elements, resulted in criticality with 48 elements. These standard elements contain approximately $650 \mathrm{~g}$ of uranium-235 per element. They are pin-type elements composed of 19 pins each on a hexagonal pitch lattice. The inner 7 pins average $58.85 \mathrm{~g}$ of uranium-235 per pin, and the outer 12 average $19.58 \mathrm{~g}$ of uranium-235 per pin.

A calibration of the worth of the safety-shutdown blades was made with this core and indicated a shutdown worth of approximately $\mathrm{l}$ per cent $\Delta \mathrm{k} / \mathrm{k}$ for each of the blades.

In an attempt to poison the core enough to allow more elements to be present at critical, each element was wrapped with a 28 -mil thickness of steel over 24 in. of its length. This steel foil was wrapped on the 1.500-in. -OD insulation liner. Seven Modification 1-type elements were added in the center 7 core positions, and another approach to critical resulted in criticality with 49 elements. The Modification 1-type elements average $845.52 \mathrm{~g}$ of uranium -235 per element. The inner 7 pins average $74.77 \mathrm{~g}$ of uranium $-235 \mathrm{each}$, and the outer 12 pins average $26.84 \mathrm{~g}$ of uranium -235 each.

Studies were made on this latter core to determine both total and epicadmium flux and power distributions throughout the unit cell of Position 1. The results of these experiments are presently being analyzed.

Next month studies of flux and power variation for the Modification l-type element will be performed at other core locations. Similar measurements will also be made for another modified element as well as for the standard elements. 


\section{BRR Loop Program}

W. G. Rieder, S. J. Basham, and W. H. Goldthwaite

Ir radiation of the fuel subas sembly designated as $1 \mathrm{~B}-2 \mathrm{~T}-2$ was concluded as scheduled on April 29. The primary objective of the experiment was to study the effect of thermal cycling on the structural components of the subassembly. Twelve hundred thermal cycles were accumulated during the $795 \mathrm{hr}$ of in-pile operation.

During periods of steady-state operation the specimen outlet-gas temperature was held at $1300 \mathrm{~F}$. Power generation was $30 \mathrm{kw}$ for the first reactor cycle of this report period. A change in the core configuration resulted in increased flux at the loop position. This change resulted in specimen powers of 38 to $42 \mathrm{kw}$ during the last 2 weeks of operation.

Present plans call for irradiation of another pin-type specimen, designated 1B-2T-1, to begin early in May. This fuel subassembly will be irradiated for several months at steady-state conditions to obtain temperature profiles, pressure drops, and other engineering information.

Analysis of the data from the flux run with the $1 \mathrm{~B}-2 \phi \mathrm{T}$ fuel subassembly has been completed. The report on this experiment will be issued soon.

\section{ETR Loop Program}

E. O. Fromm, J. V. Baum, and A. M. Rockwood

Mechanical problems associated with the blower-drive systems have delayed the insertion of the 1-3P experiment. The experiment is now scheduled for insertion at the reactor shutdown which will begin late in May.

The modified loop blowers were installed during the April reactor shutdown. During a period of operator training following the installation, attempts to obtain flow from one of the blowers were unsuccessful. A subsequent investigation revealed that the pulley on the high-speed (impeller) shaft was loose. The blower on test at Battelle was dispatched to the site. However, reactor-site scheduling precluded blower replacement and specimen insertion before the reactor startup on April 29.

At the time the blower at Battelle was sent to the reactor site, it had accumulated $2286 \mathrm{hr}$ without bearing regreasing. A special belt (now being used in all blowers) was used for the final $607 \mathrm{hr}$ of operation. Inspection of the belt and bearings kefore the unit left Battelle revealed no evidence of impending failure. 


\title{
CORROSION OF THORIUM AND URANIUM UNDER STORAGE CONDITIONS (LIVERMORE)
}

\author{
P. D. Miller
}

Electrodeposited Coatings for Thorium (SC) . . . . . . . . . V-2

Corrosion Evaluations (UCRL) . . . . . . . . . . . . . V-2

Electropolishing procedures appear to be satisfactory as methods for pretreating thorium before electroplating with protective metals. All materials for the corrosion evaluation program have been received except specimens of uranium-molybdenum and uranium-niobium alloys. 


\section{Electrodeposited Coatings for Thorium (SC)}

John G. Beach and C. L. Faust

Electroplating is being investigated as a technique for applying protective coatings to thorium. Thorium samples were furnished by Sandia (Livermore) for the preliminary electroplating studies. The lathe-tool surface finish on these samples is considered representative of that scheduled for the thorium components to be coated.

Electrochemical surface finishing was investigated to remove the mechanically worked surface metal and the subsurface oxides revealed by mechanical finishing. Oxide inclusions are removed from the surface and the surface appears uniform after electropolishing. The electropolished thorium is considered satisfactory as a basis for sound electroplated coatings.

The activation of thorium for adherent plating will be investigated next to review the known method and to survey possible improvements.

\section{Corrosion Evaluations (UCRL)}

E. F. Stephan, P. D. Miller, and F. W. Fink

Plans have been made to study the atmospheric corrosion resistance of bare and coated thorium and uranium and of uranium-molybdenum and uranium-niobium alloys. Bare and coated thorium and uranium coupons ( 2 by 3 in.) have been received. The uranium-molybdenum alloy specimens are to be shipped soon. It is planned to start the exposure program sometime in May. Initially, coupons will be subjected to screening exposures under salt-spray, constant-humidity, and humidity-plus-freezing conditions. 


\title{
A STUDY OF THE SOLUBILITY OF PLUTONIUM IN MOLTEN ALUMINUM-MAGNESIUM ALLOYS (DOW)
}

\author{
V. W. Storhok, A. A. Bauer, and R. F. Dickerson
}

A pyrometallurgical process developed by The Dow Chemical Company for the recovery of uranium from spent fuel elements is being investigated to determine its adaptability to the separation and recovery of plutonium. Basically the process is as follows:

(1) The spent fuel element is introduced to a molten aluminum bath in which uranium is highly soluble.

(2) After the uranium and other solubles are dissolved in the aluminum, the insoluble components are removed.

(3) Magnesium is added to the molten solution. This drastically reduces the solubility of the uranium, which precipitates out as $\mathrm{UAl}_{3}$. Lowering the melt temperature further reduces the uranium solubility.

Repeating the process several times results in essentially complete removal of the uranium.

An experiment is in progress to determine the behavior of plutonium when subjected to this process. For the investigation, aluminum $-10 \mathrm{w} / 0$ uranium $-5 \mathrm{w} / 0$ plutonium is being employed as the base alloy. Magnesium will be added to form two different proportions with the aluminum, $67 \mathrm{w} / 0$ aluminum-33 w/o magnesium and $33 \mathrm{w} / \mathrm{o}$ aluminum-67 w/o magnesium. Through use of a liquid-metal sampling apparatus installed in a plutonium glove box, chemical samples of the molten mixtures will be removed on heating at 500,550,600,700 and $750 \mathrm{C}$. These will be analyzed for plutonium and uranium content to determine their solubility at these temperatures.

Also to be investigated is the possibility of coprecipitation of uranium and plutonium. This portion of the study will be similar to the solubility determination with the exception that the alloys will contain only minute quantities of uranium and plutonium. Sampling will begin at $750 \mathrm{C}$ and proceed on cooling to $700,600,550$, and $500 \mathrm{C}$. 